Graduate Institute of International and Development Studies

International Economics Department

Working Paper Series

Working Paper No. HEIDWP12-2021

\title{
Fundamentals vs. policies: can the US dollar's dominance in global trade be dented?
}

\author{
Georgios Georgiadis \\ European Central Bank \\ Helena Le Mezo \\ European Central Bank \\ Arnaud Mehl \\ European Central Bank \& CEPR \\ Cédric Tille \\ The Graduate Institute, Geneva \& CEPR
}

July 2021

Chemin Eugène-Rigot 2

P.O. Box 136

CH - 1211 Geneva 21

Switzerland

(C)The Authors. All rights reserved. Working Papers describe research in progress by the author(s) and are published to elicit comments and to further debate. No part of this paper may be reproduced without the permission of the authors. 


\title{
Fundamentals vs. policies: can the US dollar's dominance in global trade be dented?*
}

\author{
Georgios Georgiadis ${ }^{\dagger}$ \\ European Central Bank
}

\author{
Helena Le Mezo ${ }^{\ddagger}$ \\ European Central Bank
}

Cedric Tille

Geneva Graduate Institute $\&$ CEPR

\author{
Arnaud Mehl ${ }^{\S}$ \\ European Central Bank \& CEPR
}

June 23, 2021

\begin{abstract}
The US dollar plays a dominant role in the invoicing of international trade, albeit not an exclusive one as more than half of global trade is invoiced in other currencies. Of particular interest are the euro, with a large role, and the renminbi, with a rising role. These two currencies are well suited to contrast the roles of economic fundamentals and policies, as European policy makers have taken a neutral stance in contrast to the promotion of the international role of the renminbi by the Chinese authorities. We assess the drivers of invoicing using the most recent and comprehensive data set for 115 countries over 1999-2019. We find that standard mechanisms that foster use of a large economy's currency predicted by theory - i.e. strategic complementarities in price setting and integration in cross-border value chains - underpin use of the dollar and the euro for trade with the United States and the euro area. These mechanisms also support the role of the dollar, but not the euro, in trade between non-US and non-euro area countries, making the dollar the globally dominant invoicing currency. Fundamentals and policies have played a contrasted role for the use of the renminbi. We find that China's integration into global trade has further strengthened the dominant status of the dollar at the expense of the euro. At the same time, the establishment of currency swap lines by the People's Bank of China has been associated with increases in renminbi invoicing, with an adverse effect on dollar use that is larger than for the euro.
\end{abstract}

Keywords: International trade invoicing, dominant currency paradigm, markets vs. policies JEL-Classification: F14; F31; F44.

\footnotetext{
${ }^{*}$ We would like to thank (without implying endorsement): Emine Boz, Camila Casas, Yin-Wong Cheung, Gita Gopinath, Philippe Martin, Angella Montfaucon, Dmitri Mukhin, Tra Nguyen, Martin Schmitz, Pinar Yesin, our discussant Hiro Ito, as well as conference and seminar participants at the ECB, the BOFIT/GRU/FU/CityUHK Conference on "China and world economy under the cloud of trade disputes: new challenges", the $13^{t h}$ FIW Research Conference on International Economics, and the annual conference of the Swiss Society of Economics and Statistics. The views expressed in this paper are those of the authors and do not necessarily reflect those of the ECB or the Eurosystem and should not be reported as such.

${ }^{\dagger}$ georgios.georgiadis@ecb.europa.eu

${ }^{\ddagger}$ helena.lemezo@ecb.europa.eu

§arnaud.mehl@ecb.europa.eu

^cedric.tille@graduateinstitute.ch
} 


\section{Introduction}

The dominant role of the US dollar as an invoicing currency in global trade is well established: roughly $40 \%$ of international trade transactions in goods are invoiced in dollars, a figure well above the US share of global trade of just 10\% (Goldberg and Tille, 2008; Gopinath, 2015; Boz et al., 2020; Gopinath et al., 2020). This dominant-currency paradigm (DCP) stands in contrast to the conventional Mundellian assumption of producer-currency pricing (PCP), under which trade prices are sticky in the currency of the exporter. It also contrasts with the assumption of local-currency pricing (LCP), under which trade prices are sticky in the currency of the importer. DCP has important implications for cross-border shock transmission as well as global business and financial cycles (Caballero et al., 2008; Gourinchas and Rey, 2013; Gourinchas, 2019; Miranda-Agrippino and Rey, 2020). The dominant status of the dollar in global trade is also related to its dominant role in the global financial system (Gopinath and Stein, 2021).

While dominant, the role of the dollar is not exclusive: more than half of global trade is invoiced in other currencies. ${ }^{1}$ Of these, two are of particular interest: the euro with a large role in invoicing, and the renminbi with a growing role. In this paper, we assess what drives the large (or growing) roles of these currencies. We are particularly interested in contrasting the role of economic fundamentals, reflecting strategic complementarities and input-output linkages, and the role of government policies, such as the People's Bank of China's global network of currency swap lines. The euro and the renminbi are particularly well suited for our research question. The former's role reflects solely fundamentals as European officials have remained neutral vis-à-vis the euro's internationalisation and emphasized that it should be determined by markets. By contrast, the renmninbi offers a case study of the role of government policies as China's officials have adopted several initiatives to promote the international use of their currency. In addition to understanding the factors that can lead to a growing international role, we consider whether the growing role of the renminbi occurs to the detriment of the dollar, the euro or other currencies.

Following the creation of the euro, some observers hypothesized that it might challenge the dollar in global importance (Portes and Rey, 1998; Chinn and Frankel, 2008). This however did not prove to be the case (Maggiori et al., 2019; Ilzetzki et al., 2019, 2020). Nevertheless, the euro is used as an invoicing currency for global trade in proportions that compare well with the dollar, which stands in contrast to theoretical predictions that increasing network returns favour use of a single currency in global trade invoicing. That the euro has held up so well, and why this is so, has received little attention in the literature so far. We shed light on this question by testing predictions from the theory on the determinants of invoicing currency choice (Bacchetta and van Wincoop, 2005; Novy, 2006; Goldberg and Tille, 2008; Gopinath et al., 2010; Mukhin, 2021) and disentangle the respective roles of LCP, PCP and DCP for the use of the euro and the dollar in the data.

While still small, the use of renminbi in trade invoicing has started to rise along with the emergence of China as a major player in the world economy. These increases have been confined to regions where trade with China has grown most significantly, such as South-East/East Asia,

\footnotetext{
${ }^{1}$ Excluding intra-euro area trade, half of global trade is invoiced in dollars and the remaining half in other currencies, including the euro with a share of about 30 percent.
} 
the Oceania/Pacific region and Sub-Saharan Africa. This is in part thanks to policies explicitly aimed at fostering its global role (Fratzscher and Mehl, 2014; Prasad, 2016; Eichengreen et al., 2019). We focus on currency swap lines established by the People's Bank of China, which have the stated objective of facilitating use of the renminbi in trade invoicing. Existing work has studied their effects (Song and Xia, 2019; Bahaj and Reis, 2020), but several important questions remain. For example, it has not been explored which currencies are displaced by increases in renminbi invoicing. In fact, from a theoretical perspective it is not clear if an emerging 'challenger' currency would displace the 'leader' currency or instead 'cannibalize' the existing 'challenger'. We provide new evidence on the effects of China's policies to promote the international use of the renminbi - and to the benefit or detriment of which currencies.

Our empirical analysis relies on an extended version of the data set assembled by Boz et al. (2020) - the most recent and comprehensive panel data set on invoicing currency patterns which is available for 115 countries over 1999-2019. Moreover, our analysis exploits a subset of the data set of Boz et al. (2020) that is not publicly available yet: information on trade invoicing in renminbi for up to 53 countries. We first test for the role of economic fundamentals using fixed effects panel regressions of countries' shares of trade invoiced in dollar/euro on measures of integration in global value chains and exposure to strategic complementarities in price setting. We consider the direct international role of a currency related to trade involving the issuing country and its indirect role related to its use as a vehicle currency in third-country trade. We assess the role of policies by focusing on the subsample of countries for which we have information on renminbi use and run regressions for the share of countries' trade invoiced in renminbi, controlling for countries' trade with China and an indicator for swap lines with the People's Bank of China.

Our analysis leads to four main results. First, strategic complementarities in price setting, stemming from the large size of the euro area and the US, underpin the direct international role of the euro and the dollar as invoicing currencies for countries' imports from the euro area and the US. In turn, we find that integration in global value chains underpins invoicing of euro area and US exports to the rest of the world (in euro and dollar, respectively) since this allows to hedge profits against variations in imported input costs arising from exchange rate fluctuations. For example, an additional percentage point increase in the share of a country's exports to the euro area (US) is associated with a $0.3(0.8)$ percentage-point increase in euro (dollar) invoicing. Hence, while both the euro's and the dollar's importance for global trade invoicing is underpinned by strategic complementarities in price setting and international input-output linkages in their trade with the rest of the world, the effects are quantitatively stronger for the dollar.

Our second finding pertains to the indirect vehicle-currency role of the euro and the dollar. We find that the dollar dominates invoicing in third-country trade, with limited evidence for a vehicle-currency role of the euro. After controlling for bilateral euro area trade, strategic complementarities in price setting in third-country trade are associated with more dollar and less euro invoicing. For example, we find that an additional percentage point increase in the share of a country's exports accounted for by more substitutable goods - those subject to more pronounced complementarities in price setting - is associated with an increase in dollar invoicing of 0.2 percentage points and a decrease in euro invoicing of 0.1 percentage points. Once controlling 
for bilateral trade with the US or the euro area, countries' integration in global value chains is robustly associated only with dollar invoicing.

Our third result shows that the growing share of China in international trade has primarily benefited the dollar, and to a lower extent the renminbi, at the expense of local currencies and the euro. Hence, our results suggest that the emergence of China and its currency have eroded the status of the euro, but strengthened that of the dollar. This finding is consistent with the counterfactual analysis based on a quantitative structural multi-country model in Mukhin (2021), which predicts that, due to history dependence, the emergence of another economy as large as the incumbent dominant-currency issuer actually strengthens the incumbent dominant currency's position at the expense of existing challenger currencies as long as it is not accompanied with shifts in global anchor currency choices and a deterioration of the incumbent's macroeconomic stability.

Finally, we provide evidence that the People's Bank of China's global network of currency swap lines has been associated with increases in renminbi invoicing, at least in countries for which China accounts for a large share of trade. This increase has occurred at the expense of both the euro and the dollar, with the impact on the dollar being more robust. This indicates that establishing which currency suffers from the rise of the Chinese currency requires that we identify the specific factors behind the rise. While fundamental factors are associated with a growing role of the renminbi at the expense of the euro, policies weaken the role of the dollar and also of, albeit to a lower degree, the euro.

Besides the aforementioned literature, our paper is related to and expands other existing work. Novy (2006) and Goldberg and Tille (2008) were among the first to test rigorously predictions from the theoretical literature on trade invoicing currency choice using cross-country data. Their sample, however, included only 24 economies - significantly less than ours - and most were advanced economies, for which vehicle-currency use is arguably less relevant than for emerging market economies (Boz et al., 2020). The data set we use in our paper, in contrast, provides invoicing currency information for 115 countries, the majority of which are emerging market economies. Ito and Chinn (2014) used the data set of Gopinath (2015) which covers around 50 countries - a substantial portion of which are advanced and/or EU economies - but did not tie their analysis to the predictions from theoretical literature on invoicing currency choice for trade. Ito and Kawai (2016) use historical data for a smaller sample of countries to study invoicing in US dollar, Japanese yen, and Deutsche Mark from the 1970s through the $1990 \mathrm{~s}$

More recently, Amiti et al. (2020) analyze invoicing currency choice theoretically and empirically using detailed firm-level data for 2017 to 2019 for Belgium. Their approach greatly advances the literature by disciplining the analysis at the level at which currency choice is actually made. Their focus on Belgian data however leaves open the question of the extent to which their findings can be generalized to other countries and, in addition, whether invoicing patterns have changed over time. Although we clearly cannot account for firm-level determinants of invoicing currency choice in our paper, we can explore invoicing currency patterns for a very large set of heterogeneous countries. Finally, Mukhin (2021) considers a quantitative structural multi-country model and shows that it can replicate well the cross-country invoicing currency 
patterns observed in the data. While our regression-based approach is less disciplined by theory, it offers more flexibility in terms of controls and calibration requirements.

The rest of this paper is structured as follows. Section 2 reviews the literature and the economic drivers of invoicing. The data and stylized facts on invoicing are presented in Section 3. The econometric framework is explained in Section 4, with the results presented in Section 5. Section 6 concludes.

\section{Insights from the literature}

\subsection{The contrasting policies of the euro area and China}

While the euro and the renminbi are both potential challengers to the role of the dollar, the attitude of policy makers in the euro area and China have been quite different. The two currencies therefore offer ideal case studies for the relative roles of economic fundamentals and policies.

Although the euro area (EA) accounts for a large share of international trade, European officials maintained a policy of neutrality regarding the internationalisation of the currency until 2019. Willem Duisenberg, the first President of the European Central Bank, stressed in his first speech that "the ECB will accept the international role of the euro as it develops as a result of market forces" (Duisenberg, 1999). This position of neutrality was driven by the assessment that an international currency status entails both economic benefits and costs (for a discussion see European Central Bank, 2019). While European officials have recently shown greater openness towards fostering the international role of the euro (European Commission, 2018; Panetta, 2020), this has yet to translate in specific policy actions. The view that the euro's international role should be determined by market forces has prevailed throughout the entire sample used in our empirical analysis.

The Chinese renminbi is seen as another potential competitor to the dollar in trade invoicing, as China has become the world's largest exporting nation (Eichengreen, 2011; Eichengreen and Lombardi, 2017; Ito, 2017).

In contrast to their European counterparts, Chinese authorities have launched several initiatives to promote the internationalisation of their currency (Chen and Cheung, 2011; Frankel, 2012; Prasad, 2016; Eichengreen et al., 2019), in contrast to the US and the EA. The renminbi is therefore a well-suited case study to examine the potential of policies in fostering the use of a currency in global trade invoicing. The policy initiatives include the 'Cross-Border Trade Renminbi Settlement Pilot Project' where authorities encouraged trade settlements in renminbi in 2009, when selected Chinese companies were first authorized to settle trade-related transactions with counterparts in Hong Kong, Macau and South-East Asia. One year later, trade with counterparts in any country could be settled in renminbi. Another policy, explained in greater detail below, is the establishment of a network of currency swap lines between the People's Bank of China (PBoC) and foreign central banks. These swap lines encourage foreign regulators to allow their banks to borrow and lend in renminbi, and enable foreign central banks to act as lenders of last resort in renminbi to local financial institutions, and thereby ultimately to exporters and importers. This, again, was meant to make the renminbi more appealing for trade invoicing 
(People's Bank of China, 2012).

\section{$2.2 \quad$ Fundamental drivers of invoicing}

An extensive theoretical literature has considered how economic fundamentals affect the invoicing currency choice. The starting point is to recognize that under sticky prices exporters choose the invoicing currency to minimize deviations of their pre-set price from the optimal price they would choose ex-post (Bacchetta and van Wincoop, 2005; Novy, 2006; Goldberg and Tille, 2008; Gopinath et al., 2010; Amiti et al., 2020). Strategic complementarities in price setting and international input-output linkages arising from global value chains (GVCs) then emerge as key determinants of the invoicing currency choice. In particular, an exporter seeks to limit deviations of (i) her price relative to those of her competitors due to strategic complementarities in price setting, and (ii) her marginal costs from her marginal revenues in the context of international input-output linkages.

Strategic complementarities imply that movements in relative prices and market shares lead to fluctuations in the desired price, because of decreasing returns to scale or changes in the elasticity of demand. Firms therefore want to keep their prices stable relative to those of competitors. For instance, if competitors use the dollar as the invoicing currency (even as a vehicle currency for trade flows between non-US countries) this induces the firm to also price in dollar. International input-output linkages matter because they induce the firm to set its price in the currency in which its marginal cost is most stable. If imported inputs in GVCs are invoiced in dollar, this induces the firm to also use the dollar for its exports in order to stabilize its margins. ${ }^{2}$

In a recent paper, Mukhin (2021) develops a quantitative multi-country, dynamic general equilibrium model which integrates strategic complementarities and international input-output linkages in a single framework. The large size of the US market encourages non-US exporters to invoice in dollars to better align their prices with those of local competitors in the US, leading to "local currency pricing" (LCP) for US imports. This stabilizes the dollar prices of intermediate inputs for US producers, induces them to invoice their exports in dollars, leading to "producer currency pricing" (PCP) for US exports. In turn, this increases the share of inputs invoiced in dollar for producers outside the US, inducing them to also invoice in dollars even for exports to countries other than the US. Moreover, the stability of the dollar exchange rate that renders it an appealing anchor currency for a large number of economies implies that dollar invoicing helps non-US exporters to better align their global export prices with those of competing non-US exporters. Thus, against the background of a large US economy and an international monetary system in which the dollar is the most widely-used anchor currency, the combination of strategic complementarities and international input-output linkages leads to "dominant currency pricing" (DCP) between non-US countries.

The pattern is summarized in the left-hand side of Figure 1. Given the large size of the EA, the same logic can apply and lead to invoicing in euro for trade flows to and from the EA, as

\footnotetext{
${ }^{2}$ Other market determinants of exporters' invoicing currency choice studied in the literature include exchange rate volatility (Devereux et al., 2004; Novy, 2006), differences in foreign exchange transaction costs across vehicle currencies (Rey, 2001; Devereux and Shi, 2013), the correlation between firms' marginal costs and the exchange rate more generally (Devereux et al., 2004; Goldberg and Tille, 2008), and the bargaining power of exporters relative to importers (Goldberg and Tille, 2013).
} 
Figure 1: Global invoicing patterns predicted by theory to emerge due to strategic complementarities and international input-output linkages

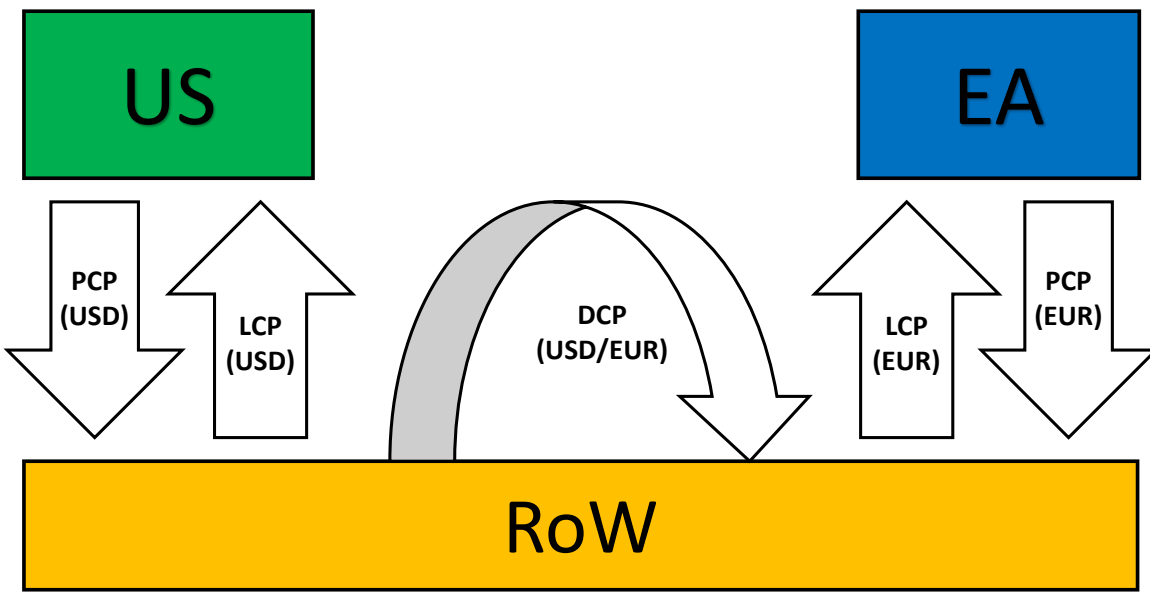

Note: 'RoW' stands for rest of the world.

well as possibly between third countries. The pattern can be summarized in four predictions regarding the use of the dollar and the euro as invoicing currencies in global trade:

Prediction LCP: Exporters to the US and the EA invoice in dollars and euros, respectively, due to the large size of these markets and the resulting strategic complementarities.

Prediction PCP: US and EA exporters invoice in dollars and euros, respectively, due to the stability of their marginal costs in their own currency.

Prediction DCP-SC: Exports of more substitutable goods between third countries (neither US nor EA) are invoiced in a vehicle currency (dollar and/or euro), due to greater strategic complementarities.

Prediction DCP-GVC: Exports between third countries (neither US nor EA) integrated in GVCs are invoiced in a vehicle currency (dollar and/or euro), due to the implied correlation between marginal costs and revenues.

Predictions LCP and PCP speak to the dominant roles of the dollar and the euro as invoicing currencies in bilateral trade with the US and the EA, while Predictions DCP-SC and DCP-GVC speak to their dominant roles as vehicle currencies in the invoicing of trade between non-US/EA countries.

\subsection{Policy drivers of invoicing}

The PBoC's policy tool of choice to promote the international role of the renminbi has been the creation of swap lines with foreign central bank. A renminbi swap line between the PBoC and another central bank is an agreement under which a foreign central bank can borrow renminbi against local currency from the PBoC. These lines have been established with the stated objective 
to facilitate trade settlements in renminbi (see People's Bank of China, 2012). ${ }^{3}$

The potential to jumpstart the internationalization of a currency through the establishment of swap lines is backed by theory. Bahaj and Reis (2020) study a small open-economy in which firms choose a currency in which to borrow to finance working capital and trade credit, as well as a currency in which they set the price for their goods. Comparing an established vehicle currency with a challenger, they derive the thresholds that must be exceeded for the challenger currency to achieve vehicle-currency status. These thresholds among other things depend on the distribution of financing costs in the challenger currency. Seen through the lens of the model of Bahaj and Reis (2020), the PBoC currency swap lines crop the right tail of the distribution of trade financing costs by providing a backstop, which helps the renminbi overcome the threshold beyond which firms consider using it as an invoicing currency. Specifically, a PBoC currency swap line may reduce the risk of a dry-up in renminbi liquidity on the offshore market in times of stress, in particular because China still maintains capital account restrictions. The emphasis on the role of trade in the model of Bahaj and Reis (2020) is consistent with the observation that PBoC swap lines have been established in particular with countries that have significant trade ties with China (Garcia-Herrero and Xia, 2015; Liao and McDowell, 2015; Lin et al., 2016).4,5

Our analysis complements those of Song and Xia (2019) as well as Bahaj and Reis (2020) along several dimensions. First, we focus on the use for invoicing rather than payment. A downside of SWIFT payment currency data typically used in these studies is that the existence of international payment hubs might introduce distortions in the data through double-counting (Batten and Szilagyi, 2016). Also, it is not obvious that the payment currency necessarily coincides with the invoicing currency. As Bahaj and Reis (2020) make predictions about the invoicing rather than the payment currency, our empirical approach is closer to theory. Second, Song and Xia (2019) focus on renminbi payment in bilateral trade with China, while we take a broader view and consider whether the renminbi is used as a vehicle currency in third-country trade. Finally, in contrast to Bahaj and Reis (2020) and Song and Xia (2019) we also assess whether increases in renminbi invoicing have come at the expense of the dollar and/or the euro.

The empirical evidence supports the effect of swap lines. Using SWIFT settlement data, Bahaj and Reis (2020) find that establishment of a PBoC swap line raises the probability that renminbi is used for payments by approximately 20\%. Also using SWIFT data, Song and Xia (2019) find that the establishment of a PBoC swap line is associated with a higher share of trade

\footnotetext{
${ }^{3}$ In contrast, the objective of the swap lines of the Federal Reserve are to mitigate risks to financial stability arising from dollar needs in the global and regional financial systems.

${ }^{4}$ Information about actual use of the swap lines is limited. The PBoC reports such information only sporadically. For example, in People's Bank of China (2011) it was disclosed that only about RMB 30 billion out of the maximum possible amount of RMB 803.5 billion at the time had been used. Similarly, People's Bank of China (2015) reported that as of end-2014 only RMB 96.5 billion out of the maximum possible amount of around RMB 3 trillion at the time had been used. In a non-exhaustive exercise, McDowell (2019) reports several instances of use of nine different countries. He finds that in the cases of South Korea, Singapore, Turkey, Russia and Hong Kong the renminbi swap lines were used largely for trade settlements. In contrast, Pakistan, Argentina, Ukraine and Mongolia used it to pay for imports from China which would otherwise be funded in US dollars, or just swapped the renminbi directly into dollars to pay others.

${ }^{5}$ Policy can also impact the internationalisation of a currency in the quantitative structural multi-country model of Mukhin (2021). In particular, as network effects give rise to path historical dependence, no firm wants to be the first to start invoicing in renminbi. As a result, the dollar remains the dominant currency even when China overtakes the US in terms of size. In this setting, China's authorities could force firms with which it trades to use the renminbi for invoicing, speeding up a transition that would otherwise take much more time.
} 
Figure 2: Country coverage, exports invoiced in dollars

Extended version of the data set of Boz et al. (2020)
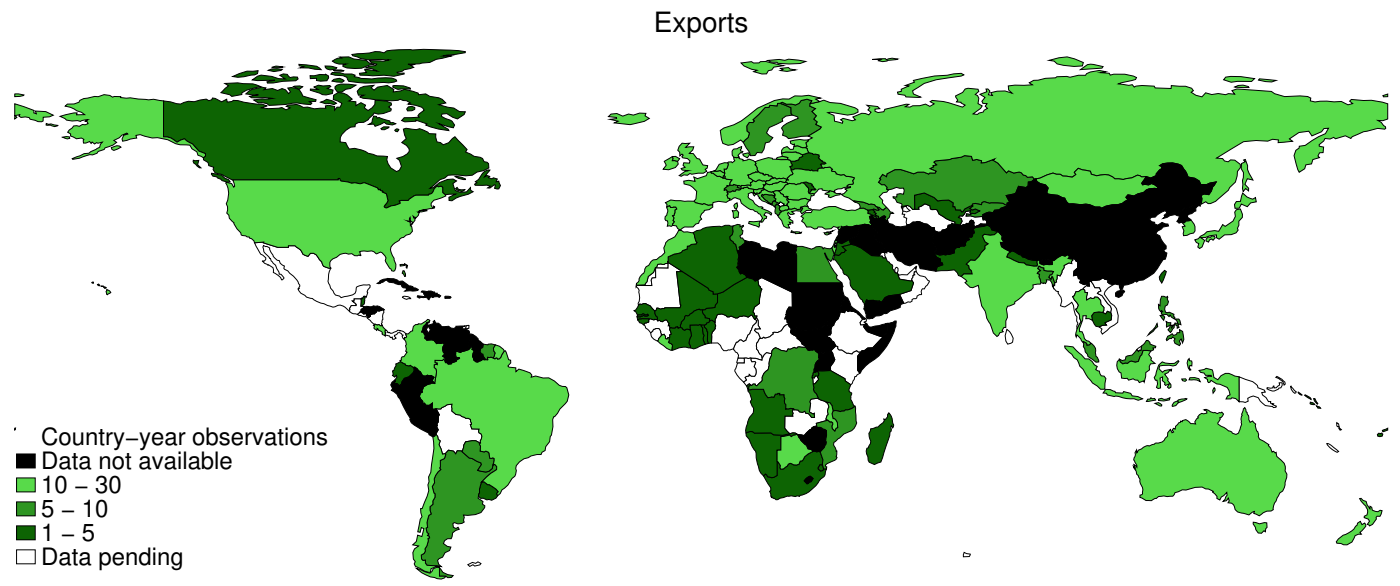

Note: The figure shows the country coverage of our data on exports invoiced in dollars. Different shades of green correspond to different numbers of available annual observations. For the countries in black, data are either unavailable (according to national authorities) or were not requested by Boz et al. (2020). Countries in white are those for which data requests by Boz et al. (2020) are pending.

settled in renminbi.

\section{Stylized facts on invoicing currency patterns}

Our analysis relies on the new cross-country panel data set on global invoicing currency patterns of Boz et al. (2020). This section presents some stylized facts, starting with the dollar and the euro and then turning to the renminbi.

\subsection{Global invoicing in dollar and euro}

Boz et al. (2020) represent the most comprehensive and up-to-date data set of trade invoicing currency, focusing on the dollar, the euro and the exporter's home currency for 102 countries from 1990 to 2019. The data come from official sources collected through the websites of central banks, statistics offices and customs/revenue authorities, as well as data requests to these institutions. We use an extended version that includes annual observations on the shares of exports and imports invoiced in dollars and euros for 115 countries. ${ }^{6}$ Figure 2 illustrates the country-coverage for exports invoiced in dollars. The coverage for imports invoiced in dollars and for trade flows invoiced in euros is similar.

Figure 3 shows the evolution of the geographical composition of trade and the use of various currencies since 1999 The left panel plots the average shares of global exports to the US, to the EA and to the rest of the world, while the right panel presents the shares of trade invoiced in dollar, euro and other currencies. ${ }^{7}$ The right panel shows that a large share of exports is

\footnotetext{
${ }^{6}$ See Table A.1 for the list of countries for which data are available and country-specific information on the data.

${ }^{7}$ The country coverage of the data set changes over time. These changes make it difficult to explore trends in invoicing currency patterns at the level of regional or income-level country aggregates, since variation would largely reflect countries entering and dropping out of the sample rather than changes in invoicing currency choices. For the purpose of presenting trends over time in Figure 3-but not for the regressions we run below-we interpolate
} 
Figure 3: Share of global exports to (and trade invoiced in) the US (dollar), EA (euro) and the rest of the world (other currencies)
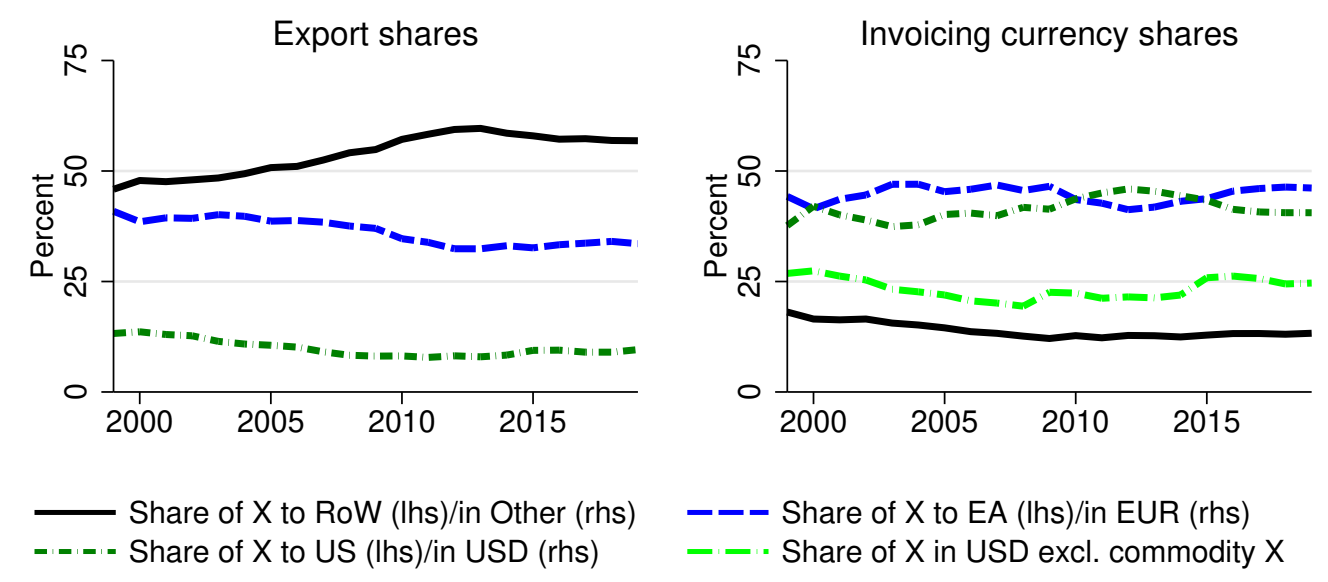

Note: The left panel shows the evolution of the share of global exports to the US, to the EA, and to the rest of the world; the right panel shows the share of global exports invoiced in dollars, euros, and other currencies. Only exports to countries for which we have invoicing data are considered. The figures use interpolated and extrapolated data as in Boz et al. (2020).

invoiced in dollars, amounting to around $40 \%$ (green dotted line). While substantial, the role of the dollar is not exclusive and the euro accounts for a similar share (blue dotted line, right panel). Where the US and the EA differ is in the relation of the invoicing share of their currencies and their weight in global trade. While the share of exports invoiced in euro is broadly in line with the share of exports going to the EA (blue dotted lines in the two panels), the share of exports invoiced in dollar is about four times as large as the share of exports destined to the US (green dotted lines in the two panels). The dominant role of the dollar in the invoicing of commodity exports plays a role in this pattern, but only offers a partial explanation as the share of non-commodity exports invoiced in dollar (green dashed line, right panel) still stands above the share of exports destined to the US.

While informative, our figures only allows for limited insights into the drivers of global trade invoicing. A more rigorous assessment of the mechanisms discussed in Section 2.2 is presented in Section 4.

\subsection{Global invoicing in renminbi}

China has become a major actor in international trade. Figure 4 shows the increase in the share of China in exports (left panels) and imports (right panel) over the last two decades. This shift is substantial, especially for countries in the Oceania/Pacific region (green bars) and South-East and East Asia (red bars).

Has the growing role of China in international trade led to more use of the renminbi as an invoicing currency? The right-hand side panel of Figure 3 shows that after 2010 the share of world exports invoiced in currencies other than the dollar and the euro increased very slightly. Over these years, the shares of the US and the euro area in global exports have not changed 
Figure 4: Share of China in exports and imports

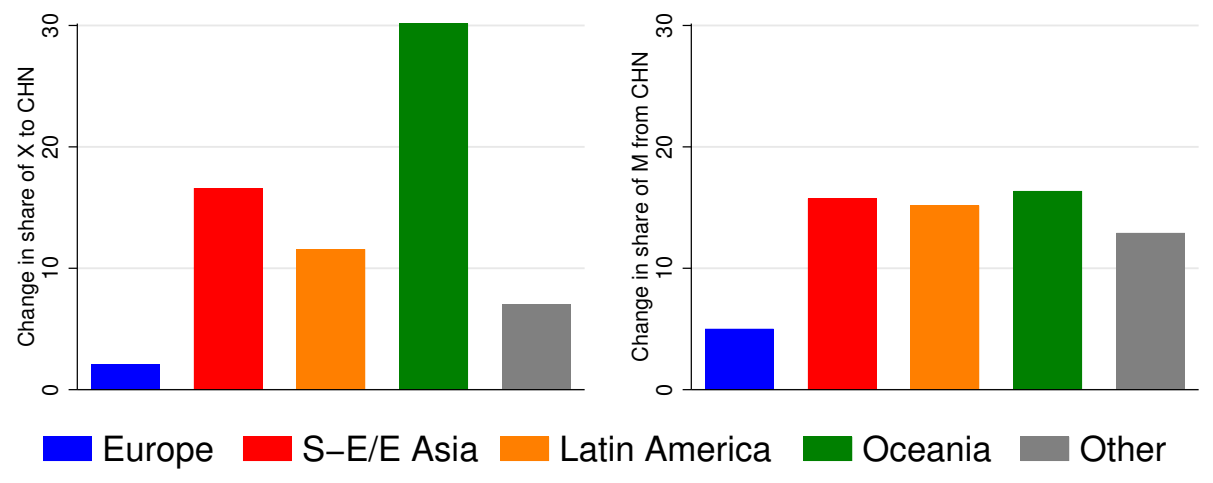

Note: The figure shows the change in the share of selected regions' total exports (left-hand side)/imports (right-hand side) destined to/sourced from China over the period 1999-2019; 'S-E/E Asia' stands for 'Southeast Asia and East Asia'. The data are from the IMF Direction of Trade Statistics.

much (left panel of Figure 3). In other words, there appears to have been some decrease in the use of the dollar and the euro as vehicle currencies since 2010. This begs the question whether the gap has been filled by the renminbi.

While the publicly available version of the data set of Boz et al. (2020) features the invoicing shares of the dollar, euro, and home currencies, it does not provide the invoicing shares of the renminbi. We can however rely on additional information on the renminbi invoicing shareshitherto not publicly available - for a subset of 38 countries for exports and 49 countries for imports. This data set is subject to several limitations. First, owing to limited data availability, the sample does not include China as well as a few South-East Asian countries (such as Vietnam, Hong Kong, Singapore, and Laos) which may plausibly account for a large share of any renminbi invoicing. Second, we do not have data on renminbi invoicing for EU countries. This notwithstanding, our cross-country panel data set on renminbi invoicing is the most comprehensive currently available.

To illustrate our data, Figure 5 depicts the country coverage of renminbi invoicing. A timeseries perspective is provided in Figure 6, which shows the evolution of the number of countries with information on renminbi invoicing (left panel) and the extent of its use (right panel). Specifically, the thick lines in the right panel show the median renminbi invoicing share across countries for exports (dashed line) and imports (solid line). While the share of trade invoiced in renminbi remains very small, it has clearly been increasing, especially for imports. Furthermore, the shares are higher for some countries: the thin lines represent the $75^{\text {th }}$ percentiles of the crosscountry distributions of invoicing shares in a given year. They stand well above the median, indicating significant cross-country heterogeneity. We exploit this heterogeneity below in order to shed light on the drivers of renminbi invoicing.

\subsection{Swap lines and invoicing}

As indicated in Section 2.3, the renminibi swap lines extended by the PBoC are aimed at promoting the international use of the currency. To gain a first sense of the policy impact, Figure 7 contrasts the share of exports and imports invoiced in renminbi between countries 
Figure 5: Country coverage renminbi invoicing of imports
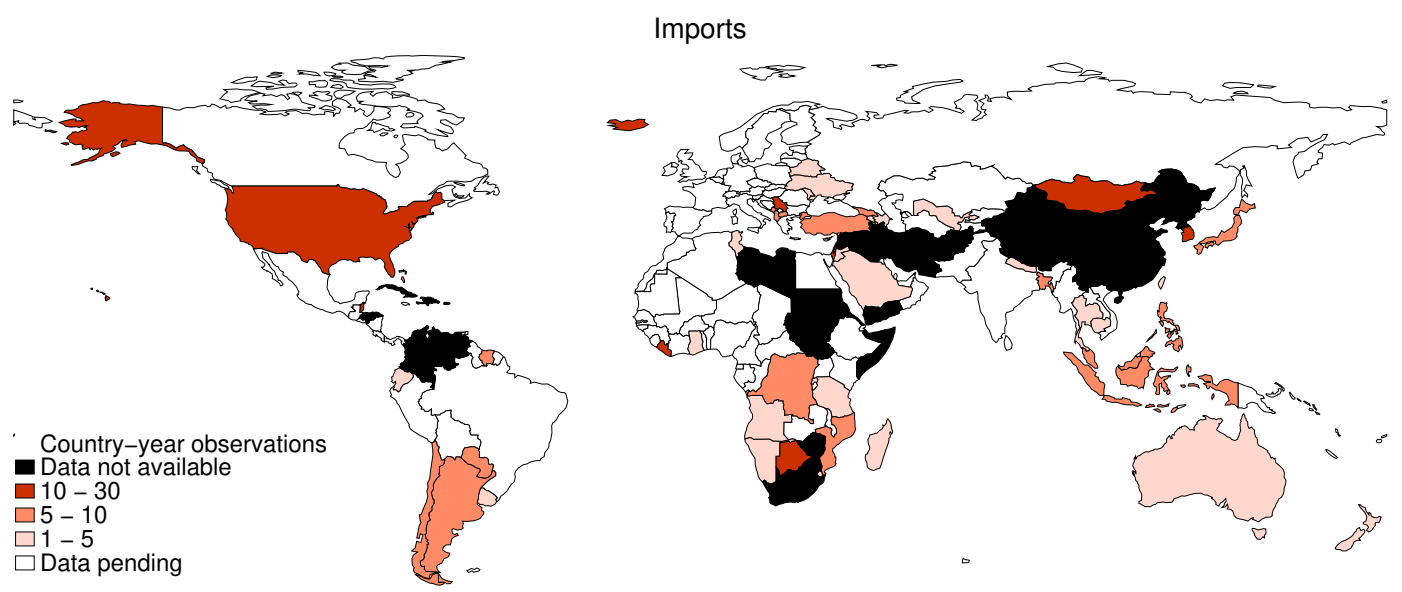

Note: See the note to Figure 2.

Figure 6: Evolution of renminbi invoicing
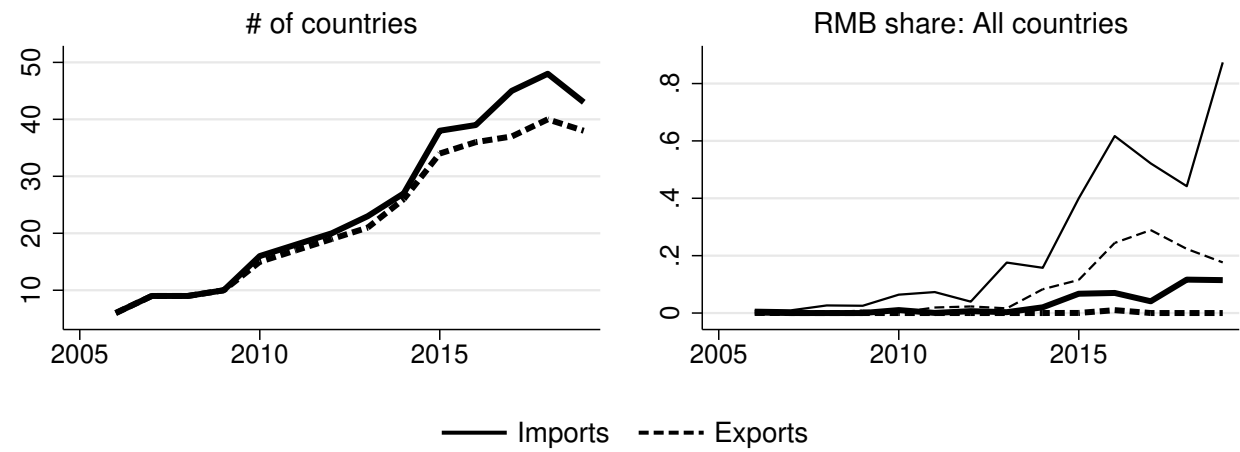

Note: The left-hand side panel shows the evolution of the number of countries for which data on renminbi invoicing are available. The thick lines in the right-hand side panel shows the evolution of the median renminbi invoicing share across countries over time; the light lines show the corresponding $75^{\text {th }}$ percentiles. Data for Mongolia are volatile and not included in order to avoid statistical distortions. 
which received a $\mathrm{PBoC}$ swap line at some point in time (left panel), and countries that did not (right panel). We clearly see that invoicing has picked up much more for countries that received a swap line. ${ }^{8}$

Figure 7: Impact of swap lines on the evolution of the share of trade invoiced in renminbi
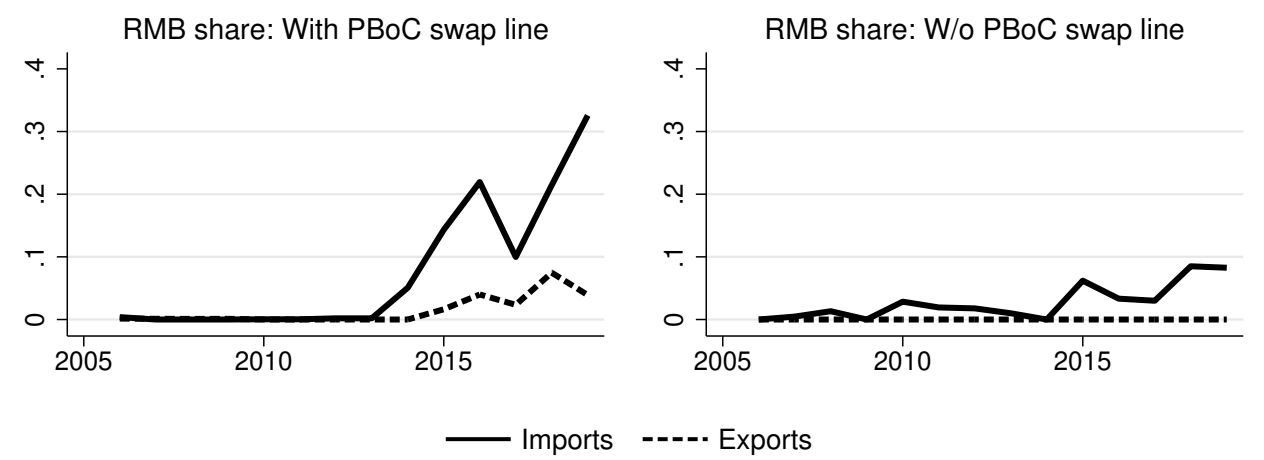

Note: The figure shows the evolution of the median share of trade invoiced in renminbi in countries which have established a currency swap line with the PBoC (left-hand side panel) and those that did not (right-hand side panel). Data for Mongolia are not included to avoid statistical distortions.

To assess whether swap lines led to changes in invoicing, or instead were implemented in response to shifting invoicing patterns due to other factors, similar to Figure 7 in Bahaj and Reis (2020), the left panel of Figure 8 suggests that renminbi invoicing picked up after the establishment of swap lines with the PBoC. This pattern should be taken with some caution, given the small (and varying) number of countries over which the averages in the left panel are calculated (see the right panel of Figure 8).

Given the outlook for China's role in the global economy and authorities' actions to promote the future international role of the renminbi, it is important to evaluate the conditions under which the share of trade invoiced in renminbi could continue to grow. We undertake a formal assessment in the next section.

\section{Empirical assessment strategy of invoicing drivers}

\subsection{Econometric specification}

To formally assess the role of fundamentals and policy measures, we follow Novy (2006), Goldberg and Tille (2008) as well as Ito and Chinn (2014) and estimate the following linear regressions:

$$
S_{i, t}^{k, \ell}=\alpha_{i}^{k, \ell}+\tau_{t}^{k, \ell}+\boldsymbol{\beta}^{k, \ell \ell} \boldsymbol{W}_{i, t}^{k, \ell}+\boldsymbol{\gamma}^{k, \ell \ell} \boldsymbol{Z}_{i, t}^{k}+u_{i, t}^{k, \ell},
$$

where $S_{i, t}^{k, \ell}$ is the share of country $i$ 's trade flow $k \in\{x, m\}$ in period $t$ invoiced in currency $\ell \in\{\$, €\}, \boldsymbol{W}_{i, t}^{k, \ell}$ is a vector of explanatory variables related to the discussion in Section 2.2 and specified in more detail below, $\boldsymbol{Z}_{i, t}^{k, \ell}$ is a vector of additional explanatory variables, and $\alpha_{i}^{k, \ell}$ and

${ }^{8}$ Table A.2 reports the list of the 41 swap lines established by the PBoC by the end of 2019 . The swap lines typically have a three-year maturity and are renewable, although some lines were not renewed at maturity. For our purpose, however, we do not distinguish between active and expired swap lines. In addition, Table A.2 reports information about the availability of data on trade invoicing in renminbi for these countries. 
Figure 8: Evolution of the share of trade invoiced in renminbi after the establishment of a PBoC swap line
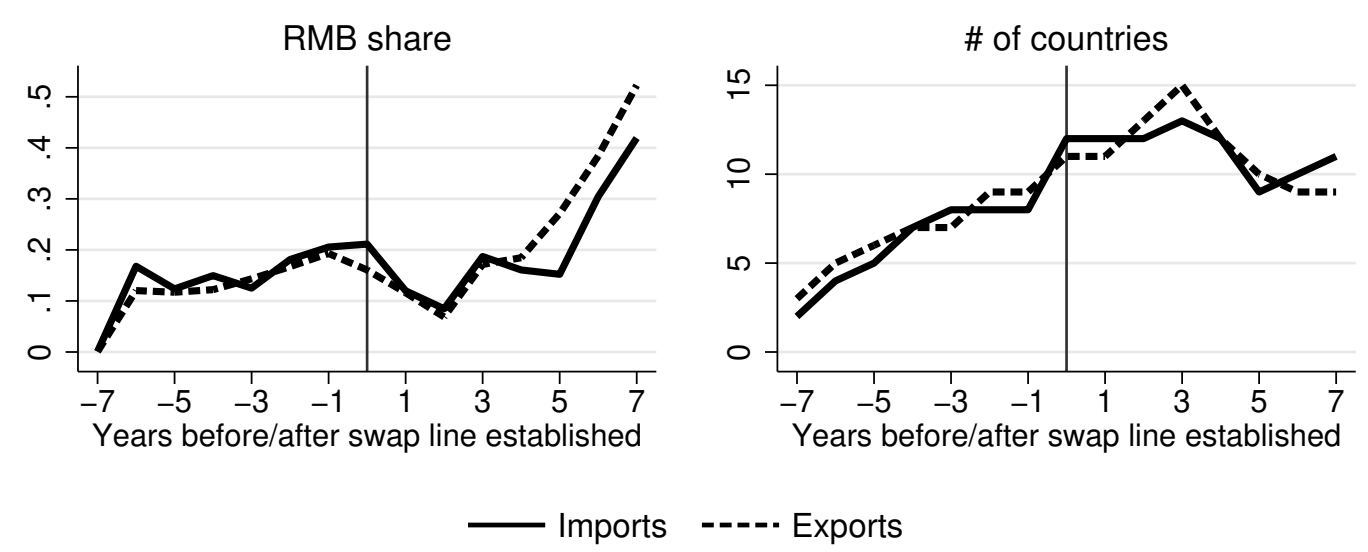

Note: The figure shows the evolution of the median share of trade invoiced in renminbi in the wake of the establishment of a currency swap line with the PBoC (indicated by the vertical line; see the left-hand side panel). The figure also shows the number of countries for which the median is calculated (see the right-hand side panel). The horizontal axis indicates years prior and after the establishment of a PBoC swap line.

$\tau_{t}^{k, \ell}$ are country and time fixed effects, respectively. ${ }^{9}$ Note that the invoicing currency shares $S_{i, t}^{k, \ell}$ refer to countries' overall exports and imports, instead of bilateral trade with the US and the EA as bilateral invoicing data are not available. Our sample goes from 1999 to 2019. As the data set of Boz et al. (2020) is an unbalanced panel, the actual time period covered is shorter for most countries. ${ }^{10}$

Against the background of the theoretical predictions discussed in Section $2.2, \boldsymbol{W}_{i, t}^{k, \ell}$ features three groups of variables in the regressions for export invoicing shares. First, we consider the share of country $i$ ' total exports destined to the issuer of currency $\ell \in\{\$, €\}$, i.e. the share of exports destined to the US or the EA (Prediction LCP). We also include the share of country $i$ 's exports to countries that anchor their currencies to the issuer of currency $\ell \in\{\$, €\} .{ }^{11,12}$ Second, we include the countries' exposure to strategic complementarities in price setting (Prediction DCP-SC). Finally, we consider the countries' integration in GVCs (Prediction DCP-GVC). The measures for exposure to strategic complementarities and integration in GVCs are discussed in Section 4.2. In the regressions for import invoicing shares we include countries' shares of imports from the US or the EA (Prediction PCP), the exposure of country $i$ 's trading-partners

\footnotetext{
${ }^{9}$ Note that logit or tobit regression models as one might be tempted to use as the invoicing shares fall in $[0,1]$ are not adequate: Neither are invoicing shares censored versions of latent variables nor are they binary.

${ }^{10}$ We exclude The Bahamas, Cyprus, and Gambia owing to statistical irregularities in their reported data. And we cannot include Burkina Faso, Benin, Guinea-Bissau, Mali, Niger and Togo because the data in Boz et al. (2020) reflect only the invoicing currency shares at the aggregate currency union (CFA-Franc-Zone) level.

${ }^{11}$ We consider countries as anchoring their currencies to the dollar or the euro when their exchange rate is not a 'free float' and the corresponding 'anchor currency' is the dollar or the euro according to Ilzetzki et al. (2020). Countries which have both the dollar and the euro as anchor currencies according to this classification are the UK, Iceland, Israel, Libya, Morocco, Madagascar, Mauritius, Poland, Singapore, Tunisia, and Samoa. We assign the UK, Iceland and Poland to the euro block and the remaining countries to the dollar block, but results hardly change when we include the share of trade with these countries as an additional explanatory variable.

${ }^{12}$ We do not enter the shares of countries' exports to the US and the EA simultaneously in $\boldsymbol{W}_{i, t}^{k, \ell}$ due their very strong negative correlation. For example, the $R$-squared of a regression of the share of countries' total exports accounted for by the EA on the corresponding shares accounted for by the US, the dollar and the euro block is around $90 \%$.
} 
to strategic complementarities in price setting in country $i$, and the integration of country $i$ 's trading partners' in GVCs.

The vector $Z_{i, t}^{k, \ell}$ includes the exchange rate between country $i$ 's currency and the dollar or the euro to account for time-series variation in invoicing currency shares due to mechanical valuation effects. ${ }^{13}$ Note that other potential explanatory variables with limited variation over time - such as a country's size, its exchange rate regime, exchange rate volatility (see Mukhin, 2021), or domestic financial market development - are largely absorbed by the country fixed effects $\alpha_{i}^{k, \ell}$. Similarly, variables that are common to all countries - such as commodity pricesare absorbed by the time fixed effects $\tau_{t}^{k, \ell}$. Finally, note that the limited length of the invoicing currency share time series for most countries precludes a meaningful computation of time-varying exchange rate volatility.

Figure 9 shows the relevance of the US and EA as export destinations. The top panel displays the distribution of the shares of exports going to the US (green bars) and the EA (blue bars), while the bottom panel shows the share of exports going to the dollar block (excluding the US, green bars) and the euro (excluding the EA, blue bars) across the countries in our sample. ${ }^{14}$ Two observations stand out. First, the EA is an important export destination for more countries than the US. Second, the (non-US) dollar block is an important export destination more frequently than the (non-EA) euro block.

Figure 9: Geographical distribution of export shares

(share of exports to US/EA (top panel), and to dollar/euro block excl. US/EA (bottom panel))
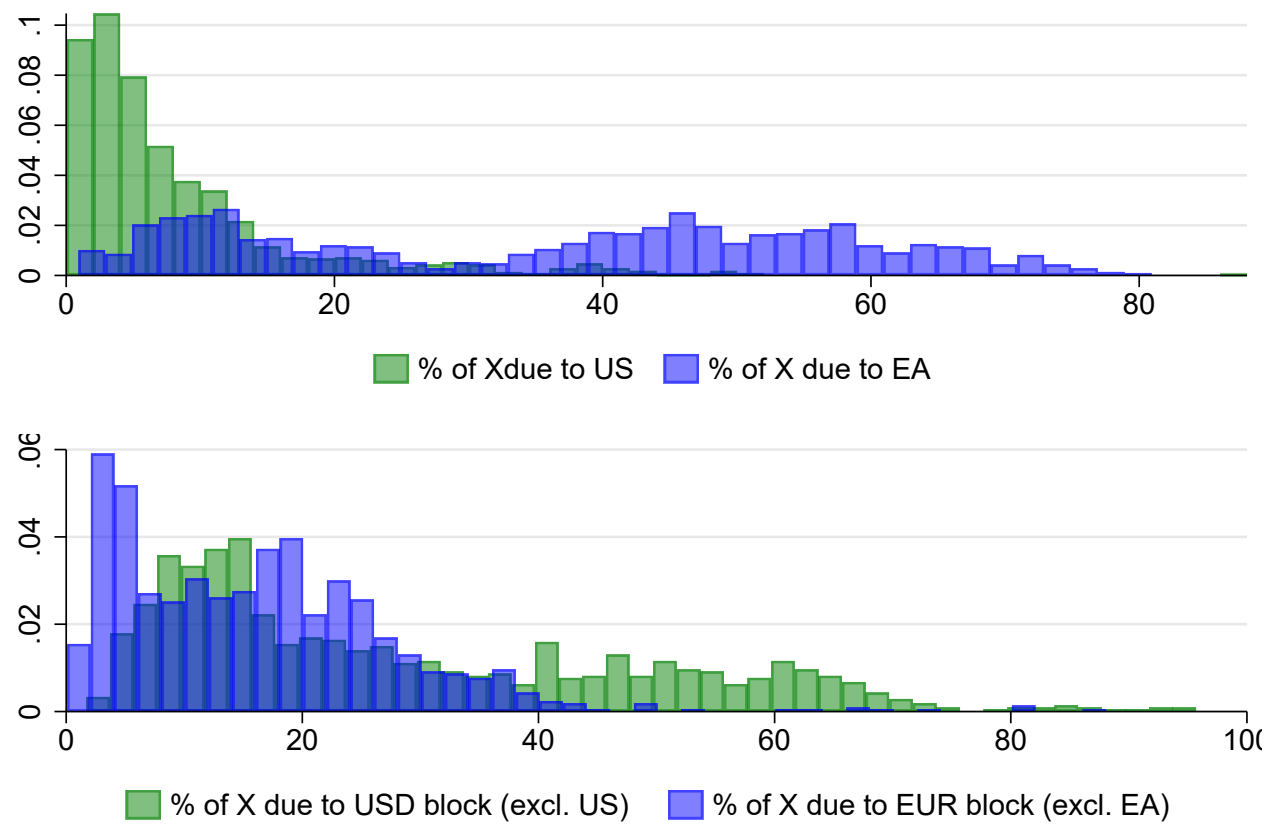

Note: The top panel shows the distribution of the shares of exports accounted for by the US and the EA, and the bottom panel the corresponding distribution for the non-US dollar block and the non-EA euro block. The histograms include only observations in our regression sample.

\footnotetext{
${ }^{13}$ We use data on nominal bilateral exchange rates from the IMF International Financial Statistics.

${ }^{14}$ We calculate export shares using data from the IMF Direction of Trade Statistics; for Taiwan we use data from the Ministry of Finance.
} 


\subsection{Measuring international input-output linkages and exposures to strategic complementarities}

The controls $\boldsymbol{W}_{i, t}^{k, \ell}$ include countries' integration in GVCs as well as their exposure to strategic complementarities. We measure the integration in GVCs by the 'vertical specialization' index of Hummels et al. (2001), which captures the imported input content of exports. ${ }^{15}$ Figure 10 shows the distribution of backward GVC integration across the countries in our sample. We see that that European countries are considerably more involved in international input-output linkages than non-European countries. ${ }^{16}$

Figure 10: Distribution of countries' backward GVC integration

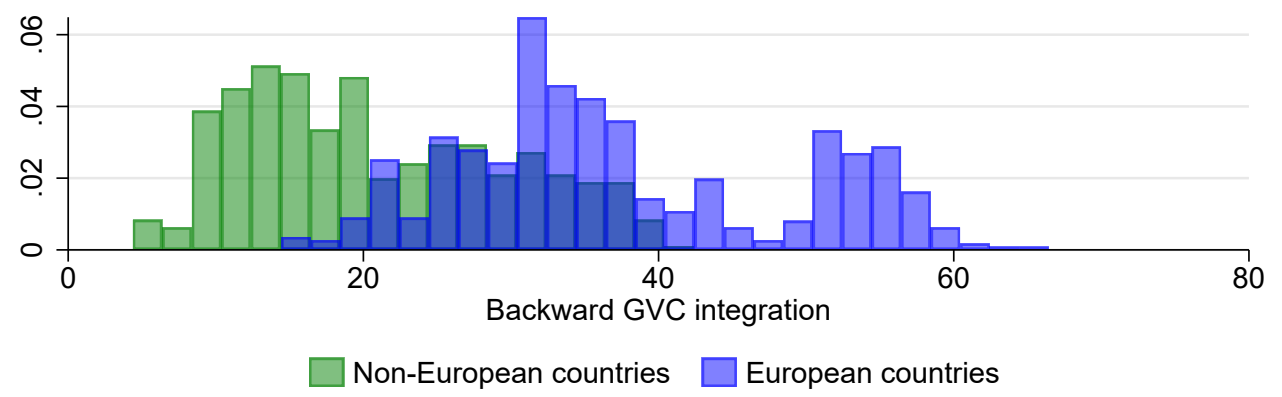

Note: The figure shows the distribution of backward GVC integration - the 'vertical specialization' index of Hummels et al. (2001) given by the imported input content of exports - for European and non-European countries. We use data from the UNCTAD-EORA Global Value Chain Database (Lenzen et al., 2013). The histograms include only observations that are used in the regressions.

Following Goldberg and Tille (2008), we measure the exposure to strategic complementarities in price setting in export markets using the sectoral composition of exports. Specifically, we use the share of a country's exports in goods considered as 'homogeneous' according to the classification of Rauch (1999). Rauch (1999) provides a careful classification of commodities at the 3- and 4-digit Standard International Trade Classification levels across three categories: 'organized exchange' goods (e.g. precious metals) have a global market. 'Reference priced' goods (e.g. some chemical products) are homogeneous, but do not have enough volume for an 'official' market. They however have reference prices that are published in specialized magazines. Rauch (1999) classifies all other goods, including most manufactured products, as 'differentiated'. Intuitively, goods traded on an organized exchange are most easily substitutable across producers, and we expect that firms producing these goods face greater strategic complementarities. In contrast, we expect that firms producing differentiated goods to be less exposed to strategic complementarities. We apply Rauch's (1999) classification to detailed United Nations COMTRADE data for countries' goods exports. ${ }^{17}$ Figure 11 shows the distribution of the share of

\footnotetext{
${ }^{15}$ We draw on data from the 'UNCTAD-EORA Global Value Chain Database' (Lenzen et al., 2013). We calculate the time-series of backward GVC integration based on foreign and domestic value added data from the EORA website. Alternative sources, such as the World-Input-Output Database (Timmer et al., 2015) and the OECD Trade in Value Added database, provide data for much smaller country samples.

${ }^{16}$ The upper panel of Figure B.1 shows countries' average backward GVC integration over the sample period.

${ }^{17}$ Taiwan is not considered explicitly among the list of countries in COMTRADE. As in Hallak and Schott (2011), we identify Taiwan's trade from flows reported by all countries in COMTRADE in which the partner is classified under UN code 490 ("other Asia, not elsewhere specified")
} 
homogeneous goods exports across countries in our sample. ${ }^{18}$ We see that countries for which these goods account for a larger share of exports are mostly located outside Europe.

Figure 11: Distribution of the share of homogeneous goods in countries' total exports

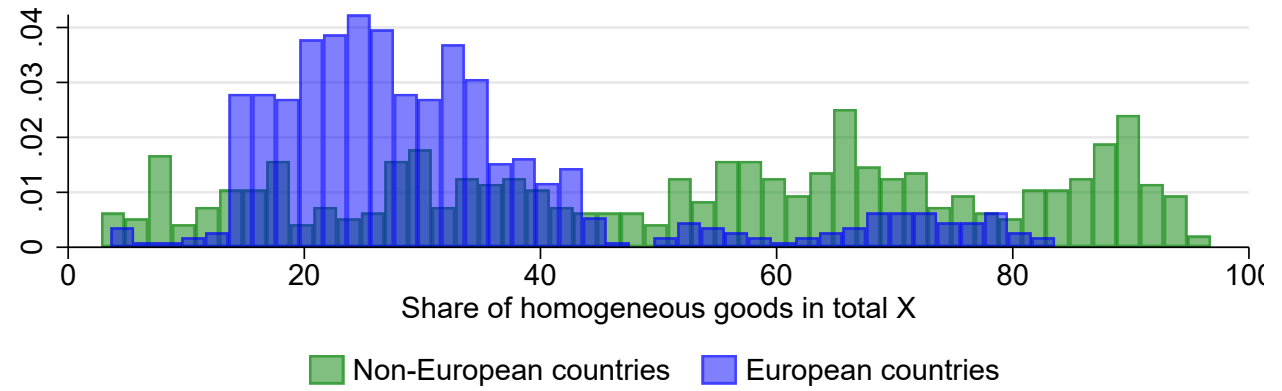

Note: The figure shows the distribution of the share of countries' total exports accounted for by homogeneous goods according to the classification of Rauch (1999). The histograms include only observations that are used in the regressions.

Because changes in exposures to strategic complementarities and the extent of GVC integration may not affect trade invoicing currency decisions instantaneously, we consider the average over the last three years for the share of homogeneous goods in total exports and backward GVC integration in $\boldsymbol{W}_{i, t}^{k, \ell}$. This said, our results are robust to whether or not we lag the variables in $\boldsymbol{W}_{i, t}^{k, \ell}$ and take averages over several periods.

\section{$5 \quad$ Econometric results}

We start our econometric assessment by considering the role of fundamentals for the use of the euro and the dollar, as focusing on these two currencies allows us to consider a broader sample. We then analyze the drivers of invoicing in renminbi, using a smaller sample, by first considering the role of economic fundamentals and then analyzing the role of policy measures.

\subsection{Invoicing in euro and dollar}

Table 1 reports regression estimates of Equation (1). The first three columns consider the share of countries' exports invoiced in dollars as the dependent variables, while the last three columns consider the share invoiced in euro. The table reports results for the full country sample (columns (1) and (4)), a subsample excluding EA countries (columns (2) and (5)), and a subsample excluding European countries (columns (3) and (6)). ${ }^{19}$ Table 2 reports the corresponding results for regressions of import invoicing currency shares.

The results in Table 1 are consistent with Prediction LCP, as a higher share of exports going to the US (EA) leads to a higher use of the dollar (euro) in export invoicing: this reflects strategic complementarities due to the large size of the destination market. In terms of magnitude, the effect is stronger for the dollar, with an additional percentage point of exports going to the US

\footnotetext{
${ }^{18}$ The bottom panel of Figure B.1 shows countries' average share of homogeneous goods in countries' total exports over the sample period.

${ }^{19}$ European countries include EA countries, other EU member states as well as Albania, Belarus, BosniaHerzegovina, Iceland, Moldova, Montenegro, Northern Macedonia, Norway, Serbia, Switzerland and Ukraine.
} 
Table 1: Regression estimates for the share of exports invoiced in dollars and euros

\begin{tabular}{|c|c|c|c|c|c|c|}
\hline & \multicolumn{3}{|c|}{ 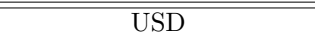 } & \multicolumn{3}{|c|}{ 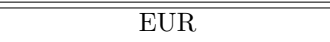 } \\
\hline & $\begin{array}{c}(1) \\
\text { Base- } \\
\text { line }\end{array}$ & $\begin{array}{l}(2) \\
\text { No } \\
\text { EA }\end{array}$ & $\begin{array}{c}(3) \\
\text { No } \\
\text { Europe }\end{array}$ & $\begin{array}{l}(4) \\
\text { Base- } \\
\text { line }\end{array}$ & $\begin{array}{l}(5) \\
\text { No } \\
\text { EA }\end{array}$ & $\begin{array}{c}(6) \\
\text { No } \\
\text { Europe }\end{array}$ \\
\hline Share of $\mathrm{X}$ to US/EA in total $\mathrm{X}$ & $\begin{array}{c}0.81^{* * * *} \\
(0.00)\end{array}$ & $\begin{array}{c}0.78^{* * *} \\
(0.00)\end{array}$ & $\begin{array}{c}0.95^{* * *} \\
(0.00)\end{array}$ & $\begin{array}{c}0.27^{* * *} \\
(0.00)\end{array}$ & $\begin{array}{l}0.19^{* *} \\
(0.01)\end{array}$ & $\begin{array}{c}0.12^{* * *} \\
(0.00)\end{array}$ \\
\hline Share of $\mathrm{X}$ to non-US USD/non-EA EUR block in total $\mathrm{X}$ & $\begin{array}{c}0.20^{* * *} \\
(0.00)\end{array}$ & $\begin{array}{c}0.17^{* * *} \\
(0.00)\end{array}$ & $\begin{array}{c}0.16^{* * *} \\
(0.01)\end{array}$ & $\begin{array}{c}0.14^{* * *} \\
(0.00)\end{array}$ & $\begin{array}{c}0.14^{* * *} \\
(0.00)\end{array}$ & $\begin{array}{c}0.05^{* * *} \\
(0.00)\end{array}$ \\
\hline Share of homogeneous goods in total $\mathrm{X}$ & $\begin{array}{c}0.23^{* * *} \\
(0.00)\end{array}$ & $\begin{array}{c}0.26^{* * *} \\
(0.00)\end{array}$ & $\begin{array}{l}0.12^{* *} \\
(0.01)\end{array}$ & $\begin{array}{c}-0.13^{* * *} \\
(0.00)\end{array}$ & $\begin{array}{c}-0.13^{* * *} \\
(0.00)\end{array}$ & $\begin{array}{c}-0.05^{* * *} \\
(0.00)\end{array}$ \\
\hline Backward GVC integration & $\begin{array}{l}-0.14 \\
(0.32)\end{array}$ & $\begin{array}{c}0.12 \\
(0.30)\end{array}$ & $\begin{array}{c}0.06 \\
(0.49)\end{array}$ & $\begin{array}{l}0.29^{* *} \\
(0.03)\end{array}$ & $\begin{array}{c}-0.00 \\
(0.97)\end{array}$ & $\begin{array}{c}0.02 \\
(0.79)\end{array}$ \\
\hline Within R-squared & 0.32 & 0.35 & 0.51 & 0.36 & 0.41 & 0.22 \\
\hline Observations & 1018 & 726 & 467 & 1025 & 729 & 470 \\
\hline Countries & 92 & 74 & 57 & 91 & 73 & 56 \\
\hline
\end{tabular}

Note: The dependent variable is the share of countries' exports invoiced in dollars (columns (1) to (3)) or in euros (columns (4) to (6)). The table reports estimates for the full sample (columns (1) and (4)), a sample excluding EA countries (columns (2) and (5)), and a sample excluding European countries (columns (3) and (6)). Inference is based on Driscoll-Kraay robust standard errors. $p$-values are reported in parentheses below the point estimates, and ${ }^{*}\left({ }^{* *}\right)\left[{ }^{* * *}\right]$ indicates statistical significance at the $10 \%(5 \%)[1 \%]$ significance level. Country and time fixed fixed effects are included in all regressions. The coefficient estimates for countries' bilateral exchange rates against the dollar and the euro are not shown to save space.

leading to an additional 0.8-1 percentage point of invoicing in dollar. By contrast, an additional percentage point of exports going to the EA only leads to an additional 0.1-0.3 percentage point of invoicing in euro. The evidence for the dollar is quantitatively stronger when European countries are dropped from the sample. In contrast, the evidence for the euro is weaker when EA and European countries are dropped. The evidence for Prediction LCP extends to considering the broader dollar and euro blocks (excluding the US and EA) as export destinations, albeit with a lower magnitude than for the US and the EA as export destinations. Again, the effect is larger for the dollar and the non-US dollar block than for the euro and the non-EA euro block.

Turning to imports, the results in Table 2 are largely consistent with Prediction PCP. A higher share of a country's imports coming from the US (EA) is associated with a higher use of the dollar (euro). Two observations are noteworthy. First, the magnitudes of the coefficient estimates reflecting Prediction PCP for the dollar in Table 2 is smaller than that reflecting Prediction LCP in Table 1. By contrast, the magnitude of the coefficient estimate in Table 2 and Table 1 are more similar when the dependent variable is the euro invoicing share, especially when EA and European countries are dropped from the sample. Second, the evidence for Prediction PCP is quantitatively stronger than for Prediction LCP for the currency blocks, especially the dollar block.

We next consider Prediction DCP-SC according to which we expect exporters to invoice in dollar and/or euro as a vehicle currency due to strategic complementarities arising from trade in homogeneous goods. Table 1 supports this prediction: countries' with a larger share of exports consisting of homogeneous goods, implying a greater exposure to strategic complementarities in destination markets, tend to invoice more in dollar. Interestingly, this use of the dollar as a vehicle currency is not observed for the euro. To the contrary, the larger role of the dollar comes at the expense of the euro. In other words, we do not observe a shift from use of the exporter's currency towards both the euro and dollar, but instead a shift from the exporter's currency and 
Table 2: Estimated results for the share of imports invoiced in dollars and euros

\begin{tabular}{|c|c|c|c|c|c|c|}
\hline & \multicolumn{3}{|c|}{ "USD } & \multicolumn{3}{|c|}{ EUR } \\
\hline & $\begin{array}{c}(1) \\
\text { Base- } \\
\text { line }\end{array}$ & $\begin{array}{l}(2) \\
\text { No } \\
\text { EA }\end{array}$ & $\begin{array}{c}(3) \\
\text { No } \\
\text { Europe }\end{array}$ & $\begin{array}{c}(4) \\
\text { Base- } \\
\text { line }\end{array}$ & $\begin{array}{l}(5) \\
\text { No } \\
\text { EA }\end{array}$ & $\begin{array}{c}\quad(6) \\
\text { No } \\
\text { Europe }\end{array}$ \\
\hline Share of M from US/EA in total M & $\begin{array}{c}0.16^{*} \\
(0.09)\end{array}$ & $\begin{array}{c}0.01 \\
(0.89)\end{array}$ & $\begin{array}{l}0.24^{* *} \\
(0.01)\end{array}$ & $\begin{array}{c}0.42^{* * *} \\
(0.00)\end{array}$ & $\begin{array}{c}0.19^{* * *} \\
(0.01)\end{array}$ & $\begin{array}{l}0.14^{*} \\
(0.08)\end{array}$ \\
\hline Share of M from non-US USD/non-EA EUR block in total M & $\begin{array}{c}0.42^{* * *} \\
(0.00)\end{array}$ & $\begin{array}{c}0.35^{* * *} \\
(0.00)\end{array}$ & $\begin{array}{c}0.35^{* * *} \\
(0.00)\end{array}$ & $\begin{array}{c}0.40^{* *} \\
(0.02)\end{array}$ & $\begin{array}{c}0.28 \\
(0.13)\end{array}$ & $\begin{array}{c}0.10 \\
(0.25)\end{array}$ \\
\hline Share of homogeneous goods in total M & $\begin{array}{c}0.26^{* * *} \\
(0.00)\end{array}$ & $\begin{array}{c}0.23^{* * *} \\
(0.00)\end{array}$ & $\begin{array}{c}0.29^{* * *} \\
(0.00)\end{array}$ & $\begin{array}{c}-0.03 \\
(0.55)\end{array}$ & $\begin{array}{c}0.03 \\
(0.45)\end{array}$ & $\begin{array}{c}0.04 \\
(0.22)\end{array}$ \\
\hline Trading-partners' backward GVC integration & $\begin{array}{c}0.10 \\
(0.86)\end{array}$ & $\begin{array}{c}0.35 \\
(0.58)\end{array}$ & $\begin{array}{l}-1.82 \\
(0.11)\end{array}$ & $\begin{array}{c}-0.64 \\
(0.18)\end{array}$ & $\begin{array}{c}-1.27^{* *} \\
(0.03)\end{array}$ & $\begin{array}{c}0.24 \\
(0.39)\end{array}$ \\
\hline Within R-squared & 0.23 & 0.21 & 0.29 & 0.30 & 0.27 & 0.25 \\
\hline Observations & 1101 & 808 & 528 & 1098 & 800 & 520 \\
\hline Countries & 99 & 81 & 61 & 98 & 80 & 60 \\
\hline
\end{tabular}

Note: The dependent variable is the share of countries' imports invoiced in dollars (columns (1) to (3)) or in euros (columns (4) to (6)). The table reports estimates for the full sample (columns (1) and (4)), a sample excluding EA countries (columns (2) and (5)), and a sample excluding European countries (columns (3) and (6)). Inference is based on Driscoll-Kraay robust standard errors. $p$-values are reported in parentheses below the point estimates, and ${ }^{*}\left({ }^{* *}\right)\left[{ }^{* * *}\right]$ indicates statistical significance at the $10 \%(5 \%)[1 \%]$ significance level. Country and time fixed fixed effects are included in all regressions. The coefficient estimates for countries' bilateral exchange rates against the dollar and the euro are not shown to save space.

the euro towards the dollar. The results for Prediction DCP-SC from the regressions of import invoicing currency shares in Table 2 are very similar, the effect for the euro being however not statistically significant.

Finally, we consider Prediction DCP-GVC according to which we expect non-US/EA exporters to invoice more in dollars and/or euros when participating more in GVCs, which renders their margins more stable in the face of exchange rate fluctuations. Tables 1 and 2 do not lend support to this prediction, as backward GVC integration is not systematically associated with higher dollar or euro invoicing. One possible explanation for the absence of evidence for such a relationship is that there may be different regional value chains, in which invoicing incentives depend on the specific value chain in which a country is involved. For instance, Figure 10 shows that the pervasiveness of international value chains is very different between European and non-European countries. ${ }^{20}$

We assess this possibility by interacting backward GVC integration with the shares of countries' total imports sourced from the US and the EA as proxies for the integration in the American vs. the European value chains. Figure 12 shows the results by presenting the marginal effects of backward GVC integration on the use of the dollar as an invoicing currency, depending on the share of imports coming from the US (left column), and the use of the euro (right column) depending on the share of imports coming from the EA. The underlying regression results are reported in Table C.1. The top row shows estimates for the full country sample, the middle row for the sample excluding EA countries, and the bottom row for the sample excluding European countries. The solid lines indicate the point estimates of the marginal effects of GVC integration

\footnotetext{
${ }^{20}$ Another possible reason for the absence of evidence for the role of integration in international input-output linkages for dollar invoicing may be that our country sample does not include Mexico and has only a single observation for Canada, the two most important countries in North America's value chain. In addition, our country sample does not include some countries that figure prominently in Asia's value chain (see Asian Development Bank, 2019), namely China, Hong Kong, Laos, Singapore, and Vietnam, presumably also dominated by dollar invoicing.
} 
(with the dashed lines representing 90\% confidence bands), while the dashed-dotted lines display the kernel density estimates of the shares of countries' total imports from the US or the EA, respectively.

The results indicate that greater backward GVC integration is associated with greater use of the dollar for export invoicing for countries that are more integrated in the American value chain (left panels), a finding that is robust across country samples. The pattern is more contrasted for the euro. For the full sample, integration in the European value chain is also associated with greater euro invoicing (recall Figure 10). However, the relationship disappears once we drop EA and other European countries from the sample. Overall, the evidence in Figure 12 is consistent with Prediction DCP-GVC in that integration in GVCs fosters invoicing in a vehicle currency, but for euro invoicing the effect seems to be confined to Europe. This is consistent with the predictions of the quantitative structural multi-country model of Mukhin (2021) that the euro is more likely to be a regional rather than a global vehicle currency (see also Amiti et al., 2020, for similar findings based on data for Belgium).

Overall, three conclusions emerge from our findings. First, the data are consistent with Prediction LCP and Prediction PCP as the dollar and the euro are used more for invoicing of countries' bilateral trade with the US and the EA. The data also indicate that Prediction LCP and Prediction PCP apply to countries' bilateral trade with the non-US dollar and the non-EA euro block. The evidence is quantitatively stronger for the dollar, which is the first explanation for why the euro plays a less important role in global trade invoicing.

Second, the data are consistent with Prediction DCP-SC as strategic complementarities (proxied by trade in homogeneous goods) lead to vehicle-currency invoicing in third-country trade that does not involve the vehicle-currency issuing country. This effect is confined to the dollar, and even comes at the expense of the euro. This is the second explanation for the less important role of the euro in global trade invoicing.

Third, the data are consistent with Prediction DCP-GVC that GVC integration induces vehicle-currency invoicing in third-country trade. This evidence is again confined to the dollar, at least when looking beyond EA countries. This is the third explanation for the less important role of the euro in global trade invoicing.

In sum, the existing theory on economic fundamentals and invoicing currency choice can explain the overall dominant role of the dollar documented in Figure 3. Moreover, our analysis suggests that the size of the EA and the large share of world trade it accounts for have been the main factors that have helped the euro prevent exclusive dominance of the dollar. In contrast, euro invoicing is hardly underpinned by its use as a vehicle currency in third-country trade.

\subsection{Invoicing in renminbi: the role of fundamentals}

Before assessing the impact of swap lines, we first assess Predictions LCP and PCP from Section 2.2. In addition to analyzing whether these drivers have impacted the use of the renminbi, we are interested in assessing whether any increase has come at the expense of the dollar or the euro.

Specifically, we run regressions analogous to those in Tables 1 and 2. In addition to consider- 
Figure 12: Marginal effects of backward GVC integration on dollar (left column) and euro (right column) export invoicing as a function of countries' imports from the US and the EA
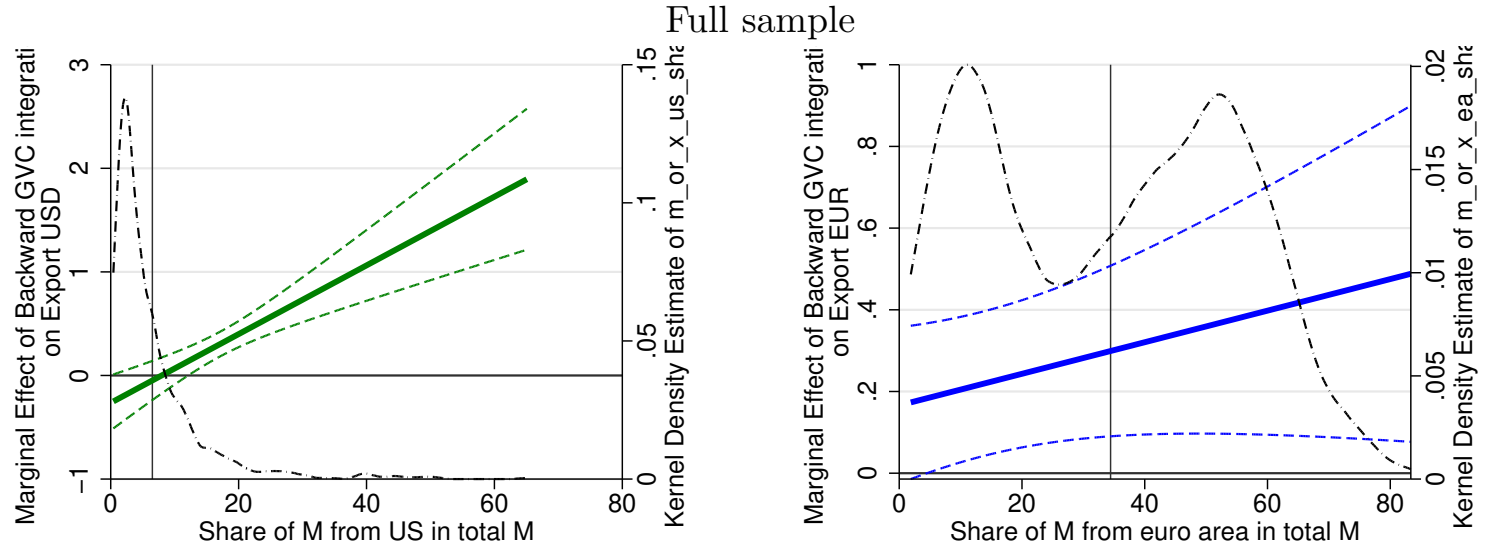

No EA countries
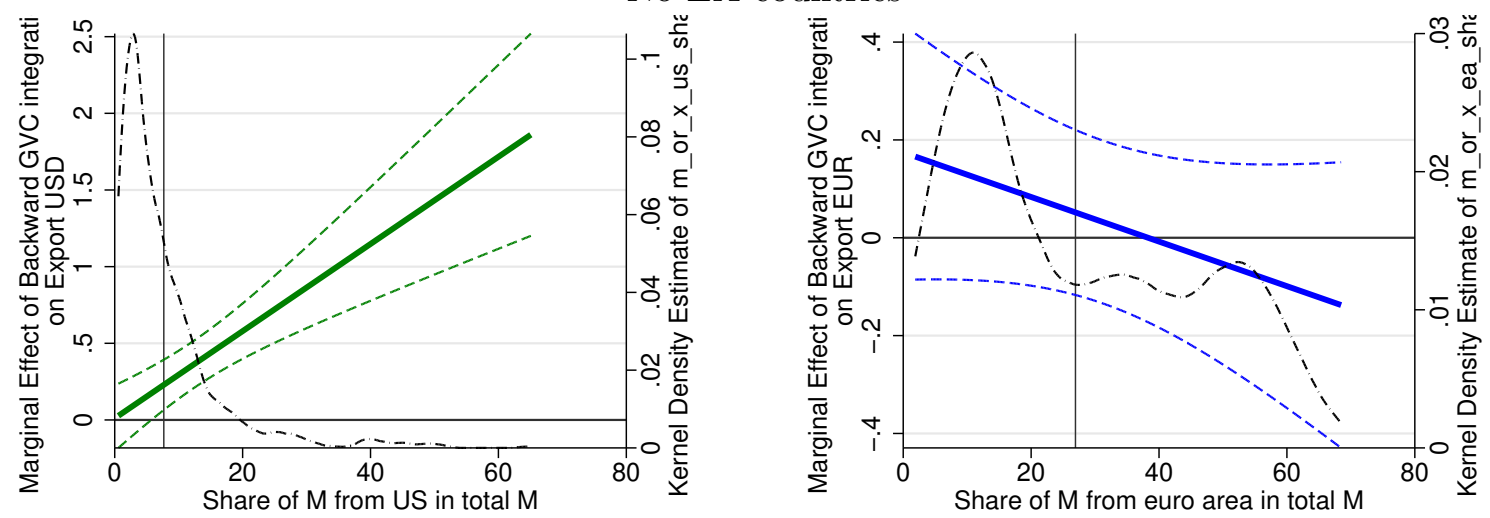

No European countries
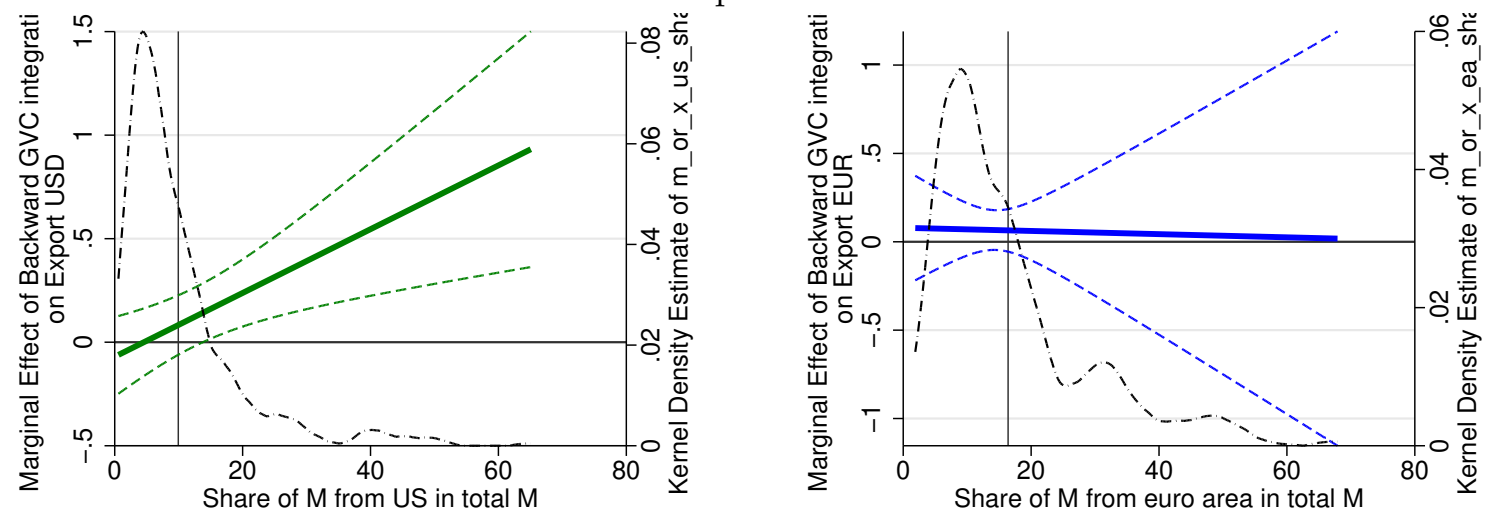

Note: The figure shows the marginal effects of backward GVC integration on dollar and euro invoicing from Table C.1. The solid lines represent the point estimates, the dashed lines $90 \%$ confidence bands, and the dash-dotted lines kernel density estimates of the distribution of the share of countries' total imports sourced from the US/EA. 
ing the shares of trade invoicing in dollar and euro as dependent variables, we consider the shares invoiced in renminbi and the share invoiced in all other currencies (non-dollar/euro/renminbi currencies). We include the share of countries' trade with China as another explanatory variable in addition to the share of trade with the US and the EA. We rely on observations since 2011, the year from which China's authorities allowed trade settlements in renminbi with counterparts without restrictions. In all regressions, we only consider countries for which we have renminbi invoicing share data, leading to a smaller sample. ${ }^{21}$ As before, we control for the share of homogeneous goods in total trade, backward GVC integration, US/EA and non-US/EA dollar/euroblock trade shares, as well as the bilateral dollar, euro and renminbi exchange rates. ${ }^{22}$

Table 3 presents the results for exports (columns (1) to (4)) and imports (columns (5) to (8)). For brevity, we only report the coefficient on the share of trade going to or coming from China. Countries with a higher share of exports going to China make greater use of the dollar in invoicing (column (1)), primarily at the expense of the euro (column (2)). Moreover, a higher share of exports going to China is associated with higher use of renminbi and lower use of 'other' currencies (columns (3) and (4)), but the coefficients are estimated somewhat imprecisely. The small effect in case of renminbi invoicing is consistent with the small increase documented in Figure 6. The results thus suggest that growing export exposure to China has been associated with greater invoicing in dollar, consistent with a variant of Prediction LCP considering that China is part of the dollar block in the analysis in Section 5.1, and renminbi, consistent with Prediction LCP.

The pattern for imports is broadly similar. Growing import exposure to China has been associated with greater dollar use, as well as additional use of the renminbi at the expense of the euro and 'other' currencies. The dollar effect is the only one that is estimated with reasonable precision. Table C.3 documents that the results for dollar and euro invoicing are similar when we include the data for all countries in the regression.

Figure 4 shows that the role of China in international trade is quite heterogeneous across regions. We therefore refine our results at the global level from Table 3 to account for regional heterogeneity. Specifically, we introduce separate, region-specific coefficients for trade exposures to China. As a first step, we introduce separate coefficients only for European and non-European countries in Table 4. The results indicate stark differences across European and non-European countries. For European countries, a rising role of China as an export destination raised the use of the dollar at the expense of all other currencies, even if the estimates are rather imprecise. In

\footnotetext{
${ }^{21}$ We drop the data on invoicing of exports of Mongolia because they are very volatile and in order to avoid that one country impacts the estimates disproportionately. The share of exports invoiced in renminbi of Mongolia increased from essentially zero in 2007 to $30 \%$ in 2013, oscillating somewhat after that. Also, the share of Mongolia's total exports destined to China has amounted to around $90 \%$ since 2010. Not surprisingly, regressions that include data for Mongolia produce stronger evidence for the relationship between trade with China and renminbi invoicing.

${ }^{22}$ For the regressions of the share of trade invoiced in dollars, we remove the share of countries' trade accounted for by China from the share of trade accounted for by the non-US dollar block. For the dollar (euro) invoicing share regressions we continue to control for the share of countries' total trade accounted for by the US (EA) when entering the share of countries' total trade accounted for by China; in contrast to the shares of trade accounted for by the US and the EA the shares of trade accounted for by China and the US/EA are hardly correlated. For example, if we regress the share of countries' total exports accounted for by the EA on the corresponding share accounted for by China and the non-EA euro block the $R$-squared is only around $13 \%$, and even lower in the corresponding regression for the US trade share.
} 
Table 3: Impact of trade with China on invoicing

\begin{tabular}{lccccccccccc}
\hline \hline & \multicolumn{4}{c}{ Exports } & & \multicolumn{3}{c}{ Imports } \\
\cline { 2 - 3 } & & $(1)$ & $(2)$ & $(3)$ & $(4)$ & & $(5)$ & $(6)$ & $(7)$ & $(8)$ \\
& USD & EUR & RMB & Other & USD & EUR & RMB & Other \\
\hline Share of X/M to/from CH in total X/M & $0.39^{* * *}$ & $-0.14^{*}$ & 0.02 & -0.06 & & $0.30^{* *}$ & -0.11 & 0.02 & -0.05 \\
& $(0.00)$ & $(0.06)$ & $(0.10)$ & $(0.11)$ & & $(0.04)$ & $(0.28)$ & $(0.16)$ & $(0.78)$ \\
\hline Within R-squared & 0.33 & 0.39 & 0.14 & 0.09 & & 0.26 & 0.34 & 0.24 & 0.10 \\
Observations & 251 & 258 & 214 & 211 & & 301 & 301 & 262 & 258 \\
Countries & 38 & 38 & 38 & 37 & & 49 & & 49 & 49 & 48 \\
\hline \hline
\end{tabular}

Note: The dependent variable is the share of countries' exports/imports invoiced in dollars (column $(1) /(5))$, in euros (column $((2) /(6))$, in renminbi (column $((3) /(7))$, and in currencies other than the dollar, the euro, and the renminbi (column $(4) /(8)$ ). Inference is based on Driscoll-Kraay robust standard errors. $p$-values are reported in parentheses below the point estimates, and ${ }^{*}\left({ }^{* *}\right)\left[{ }^{* * *}\right]$ indicates statistical significance at the $10 \%(5 \%)[1 \%]$ significance level. Country and time fixed effects are included in all regressions. The coefficient estimates for the share of homogeneous goods in total trade, backward GVC integration, US/EA and dollar/euro-block trade shares as well as exchange rates are not reported to save space.

contrast, the effects are statistically significant for imports: a larger share of China as a source of imports shifted invoicing towards the euro at the expense of all other currencies, including the dollar and the renminbi. Turning to non-European countries, higher exposure to China was associated with greater use of the dollar and the renminbi primarily at the expense of the euro, both for exports and imports. Moreover, for non-European countries a higher exposure to China is associated with higher use of renminbi and lower use of 'other' currencies (columns (3), (4), (7) and (8)), albeit the coefficients are again estimated less precisely. Table C.4 again documents that the results for dollar and euro invoicing are similar when we include the data for all countries in the regression.

Table 4: Impact of trade with China on invoicing: Europe vs. Non-Europe

\begin{tabular}{|c|c|c|c|c|c|c|c|c|}
\hline & \multicolumn{4}{|c|}{ Exports } & \multicolumn{4}{|c|}{ Imports } \\
\hline & $(1)$ & $(2)$ & (3) & $(4)$ & $(5)$ & $(6)$ & $(7)$ & $(8)$ \\
\hline & USD & EUR & RMB & Other & USD & EUR & $\mathrm{RMB}$ & Other \\
\hline \multicolumn{9}{|c|}{ Share of $\mathrm{X} / \mathrm{M}$ to/from $\mathrm{CH}$ in total $\mathrm{X} / \mathrm{M}$} \\
\hline $\mathrm{x}$ Europe dummy & $\begin{array}{c}0.90 \\
(0.22)\end{array}$ & $\begin{array}{l}-0.47 \\
(0.45)\end{array}$ & $\begin{array}{l}-0.03 \\
(0.10)\end{array}$ & $\begin{array}{l}-0.32 \\
(0.13)\end{array}$ & $\begin{array}{c}-0.83^{* * *} \\
(0.00)\end{array}$ & $\begin{array}{c}1.43^{* * *} \\
(0.00)\end{array}$ & $\begin{array}{c}-0.07^{* * *} \\
(0.00)\end{array}$ & $\begin{array}{c}-0.82^{* * *} \\
(0.00)\end{array}$ \\
\hline $\mathrm{x}$ Non-Europe dummy & $\begin{array}{c}0.35^{* * *} \\
(0.00)\end{array}$ & $\begin{array}{l}-0.12^{*} \\
(0.05)\end{array}$ & $\begin{array}{c}0.02^{*} \\
(0.08)\end{array}$ & $\begin{array}{l}-0.01 \\
(0.89)\end{array}$ & $\begin{array}{l}0.34^{* *} \\
(0.04)\end{array}$ & $\begin{array}{l}-0.13 \\
(0.13)\end{array}$ & $\begin{array}{c}0.02 \\
(0.11)\end{array}$ & $\begin{array}{l}-0.14 \\
(0.35)\end{array}$ \\
\hline Within R-squared & 0.34 & 0.40 & 0.15 & 0.08 & 0.29 & 0.42 & 0.26 & 0.11 \\
\hline Observations & 251 & 258 & 214 & 257 & 301 & 301 & 262 & 301 \\
\hline Countries & 38 & 38 & 38 & 38 & 49 & 49 & 49 & 49 \\
\hline
\end{tabular}

Note: The dependent variable is the share of countries' exports/imports invoiced in dollars (column (1)/(5)), in euros (column $((2) /(6))$, in renminbi (column $((3) /(7))$, and in currencies other than the dollar, the euro, and the renminbi (column $(4) /(8)$ ). Inference is based on Driscoll-Kraay robust standard errors. $p$-values are reported in parentheses below the point estimates, and $\left.{ }^{*}\left({ }^{* *}\right){ }^{[* *}\right]$ indicates statistical significance at the $10 \%(5 \%)$ [1\%] significance level. Country and time fixed effects are included in all regressions. The coefficient estimates for the share of homogeneous goods in total trade, backward GVC integration, US/EA and dollar/euro-block trade shares as well as exchange rates are not reported to save space.

Table 5 refines the analysis further, splitting the non-European countries into several regions. Among non-European countries, higher export exposure to China has led to more dollar invoicing in all regions (column (1)). This has come at the expense of the euro (column (2)), especially in the regions closest to China (Oceania and South-East/East Asia). The use of the euro 
increased - although estimated rather imprecisely - only in Sub-Saharan Africa, a region with strong historical ties and in some cases exchange rate pegs to the euro. The impact on renminbi invoicing is quite heterogeneous (column (3)). Higher renminbi invoicing is observed for countries in the Oceania/Pacific region - a plausible finding given that these have exhibited by far the largest increase in export exposure to China (see Figure 4). Invoicing of exports in 'other' currencies has generally fallen, although the estimates tend to be imprecise (column (4)).

In terms of imports, Table 5 reveals that for non-European countries higher exposure to China is systematically associated with more dollar invoicing (column (5)), again mostly at the expense of the euro (column (6)), and 'other' currencies (column (8)). The impact on renminbi use displays noteworthy regional heterogeneities. It is boosted by higher import exposure to China in countries in South-East/East Asia and the Oceania/Pacific region, the two regions with the largest increases in trade exposure to China (see Figure 4). The finding that renminbi internationalisation in the context of invoicing currency choice is following regional patterns is consistent with findings in the context of foreign-exchange turnover (Cheung, 2015; Ehlers et al., 2016; Cheung et al., 2019). Again, Table C.5 documents that the results for dollar and euro invoicing are similar when we include the data for all countries in the regression.

Table 5: Impact of trade with China on invoicing: Accounting for regional heterogeneity

\begin{tabular}{|c|c|c|c|c|c|c|c|c|}
\hline & \multicolumn{4}{|c|}{ Exports } & \multicolumn{4}{|c|}{ Imports } \\
\hline & $\begin{array}{l}(1) \\
\text { USD }\end{array}$ & $\begin{array}{c}(2) \\
\text { EUR }\end{array}$ & $\begin{array}{c}(3) \\
\text { RMB }\end{array}$ & $\begin{array}{c}(4) \\
\text { Other }\end{array}$ & $\begin{array}{c}(5) \\
\text { USD }\end{array}$ & $\begin{array}{c}(6) \\
\text { EUR }\end{array}$ & $\begin{array}{c}(7) \\
\text { RMB }\end{array}$ & $\begin{array}{c}\text { (8) } \\
\text { Other }\end{array}$ \\
\hline \multicolumn{9}{|l|}{ Share of $\mathrm{X} / \mathrm{M}$ to/from $\mathrm{CH}$ in total $\mathrm{X} / \mathrm{M}$} \\
\hline $\mathrm{x}$ Europe dummy & $\begin{array}{c}0.90 \\
(0.22)\end{array}$ & $\begin{array}{l}-0.49 \\
(0.44)\end{array}$ & $\begin{array}{l}-0.03^{*} \\
(0.08)\end{array}$ & $\begin{array}{l}-0.03 \\
(0.77)\end{array}$ & $\begin{array}{c}-0.66^{* *} \\
(0.01)\end{array}$ & $\begin{array}{c}1.36^{* * *} \\
(0.00)\end{array}$ & $\begin{array}{c}-0.06^{* * *} \\
(0.00)\end{array}$ & $\begin{array}{c}-0.71^{* * *} \\
(0.00)\end{array}$ \\
\hline x S-E/E Asia dummy & $\begin{array}{c}0.43^{* * *} \\
(0.00)\end{array}$ & $\begin{array}{c}-0.50^{* * *} \\
(0.00)\end{array}$ & $\begin{array}{l}-0.03 \\
(0.32)\end{array}$ & $\begin{array}{c}0.08 \\
(0.41)\end{array}$ & $\begin{array}{c}0.65^{* * *} \\
(0.00)\end{array}$ & $\begin{array}{c}-0.24^{* *} \\
(0.02)\end{array}$ & $\begin{array}{c}0.10^{* * * *} \\
(0.00)\end{array}$ & $\begin{array}{c}-0.45^{* * *} \\
(0.01)\end{array}$ \\
\hline $\mathrm{x}$ Latin America dummy & $\begin{array}{l}0.24^{* *} \\
(0.03)\end{array}$ & $\begin{array}{l}-0.10 \\
(0.22)\end{array}$ & $\begin{array}{c}-0.01^{* * *} \\
(0.00)\end{array}$ & $\begin{array}{l}-0.01 \\
(0.89)\end{array}$ & $\begin{array}{l}0.45^{*} \\
(0.05)\end{array}$ & $\begin{array}{l}-0.23^{*} \\
(0.05)\end{array}$ & $\begin{array}{l}-0.02 \\
(0.11)\end{array}$ & $\begin{array}{l}-0.15 \\
(0.48)\end{array}$ \\
\hline x Oceania dummy & $\begin{array}{c}0.41^{* * *} \\
(0.00)\end{array}$ & $\begin{array}{c}-0.19^{* *} \\
(0.01)\end{array}$ & $\begin{array}{l}0.12^{* *} \\
(0.01)\end{array}$ & $\begin{array}{l}-0.23 \\
(0.17)\end{array}$ & $\begin{array}{l}1.30^{*} \\
(0.09)\end{array}$ & $\begin{array}{c}-0.53^{* * *} \\
(0.00)\end{array}$ & $\begin{array}{c}0.12^{* * *} \\
(0.00)\end{array}$ & $\begin{array}{c}0.03 \\
(0.84)\end{array}$ \\
\hline x Sub-Saharan Africa dummy & $\begin{array}{c}0.36^{* * *} \\
(0.01)\end{array}$ & $\begin{array}{c}0.08 \\
(0.38)\end{array}$ & $\begin{array}{c}0.01 \\
(0.32)\end{array}$ & $\begin{array}{l}-0.11 \\
(0.14)\end{array}$ & $\begin{array}{l}-0.26 \\
(0.43)\end{array}$ & $\begin{array}{c}0.04 \\
(0.73)\end{array}$ & $\begin{array}{c}0.01 \\
(0.48)\end{array}$ & $\begin{array}{c}0.25 \\
(0.38)\end{array}$ \\
\hline Within R-squared & 0.35 & 0.41 & 0.31 & 0.13 & 0.34 & 0.43 & 0.37 & 0.15 \\
\hline Observations & 251 & 258 & 214 & 211 & 301 & 301 & 262 & 258 \\
\hline Countries & 38 & 38 & 38 & 37 & 49 & 49 & 49 & 48 \\
\hline Countries in groups & $\begin{array}{l}5 / 8 / \\
8 / 2 / 6\end{array}$ & $\begin{array}{l}5 / 8 / \\
8 / 2 / 6\end{array}$ & $\begin{array}{l}5 / 8 / \\
8 / 2 / 6\end{array}$ & $\begin{array}{l}5 / 8 / \\
8 / 2 / 6\end{array}$ & $\begin{array}{l}8 / 10 / \\
7 / 2 / 10\end{array}$ & $\begin{array}{l}8 / 10 / \\
7 / 2 / 10\end{array}$ & $\begin{array}{l}8 / 10 / \\
7 / 2 / 10\end{array}$ & $\begin{array}{l}8 / 10 / \\
7 / 2 / 9\end{array}$ \\
\hline
\end{tabular}

Note: The dependent variable is the share of countries' exports/imports invoiced in dollars (column $(1) /(5))$, in euros $($ column $((2) /(6))$, in renminbi (column $((3) /(7))$, and in currencies other than the dollar, the euro, and the renminbi $($ column $(4) /(8))$. Inference is based on Driscoll-Kraay robust standard errors. $p$-values are reported in parentheses below the point estimates, and ${ }^{*}(* *)[* * *]$ indicates statistical significance at the $10 \%(5 \%)[1 \%]$ significance level. Country and time fixed effects are included in all regressions. The coefficient estimates for the share of homogeneous goods in total trade, backward GVC integration, US/EA and dollar/euro-block trade shares as well as exchange rates are not reported to save space. Also, the coefficient estimate of the group of countries that do not belong to Europe, SouthEast and East Asia, Latin America, Oceania and Sub-Saharan Africa are not shown to save space. The last row provides information on the number of countries for which the regional dummy variable equals unity in the regression in each column in the order they appear in the rows in the main part of the regression table.

Overall, our results suggest that the emergence of China as a major trading partner has already been associated with shifts in invoicing currency patterns. Renminbi invoicing has changed along regional lines, with increases in countries in the Oceania/Pacific region and in South-East/East Asia. So far, this has occurred exclusively at the expense of the euro and 
'other' currencies. The impact of economic fundamentals on renminbi invoicing have therefore not challenged the globally dominant role of the dollar so far. In fact, dollar invoicing has increased systematically along with countries' growing trade exposures to China. The euro has generally been losing ground as an invoicing currency as trade exposures to China have grown, with the notable exception of European countries' import invoicing. The latter two findings are consistent with the counterfactual analysis based on a quantitative structural multicountry model in Mukhin (2021). In particular, Mukhin (2021) shows that due to path historical dependence the emergence of another economy as large as the incumbent dominant-currency issuer actually strengthens the incumbent dominant currency's position, and that this occurs at the expense of existing challenger currencies. Moreover, Mukhin (2021) shows that only when the emerging challenger's currency is increasingly chosen as an anchor and macroeconomic stability of the incumbent dominant-currency issuer deteriorates and its inflation increases - for example due to rising government debt and inability to raise taxes sufficiently — does a switch in global invoicing currency patterns occur.

\subsection{Invoicing in renminbi: the role of policy}

As Chinese authorities have promoted the international use of the renminbi in trade invoicing through initiatives such as the 'Cross-Border Trade Renminbi Settlement Pilot Project', we now consider whether these efforts have fostered an increasing invoicing in renminbi, and whether this has occurred at the expense of the dollar and/or the euro.

We undertake our econometric assessment of the impact of swap lines by running regressions analogous to those underlying Tables 1 and 2. The controls also include the share of China in countries' exports and imports, as well as a dummy variable that equals one starting from the year in which a country signed a currency swap line with the PBoC and zero otherwise. ${ }^{23}$

Table 6 reports the results for the regressions with the renminbi invoicing share as the dependent variables, for exports (columns (1) to (3)) and imports (columns (4) to (6)). For brevity, we focus on the coefficients on the swap line dummy, and the dummy interacted with the share of China in the export and import flows. The swap line itself does not have a clear effect: the coefficient on the PBoC swap line dummy variable in columns (1) and (4) is estimated very imprecisely. However, introducing an interaction between the dummy and the share of China in countries' trade changes the results. While the coefficient on the dummy in columns (2) and (5) is negative, the coefficient on the interaction is positive. This indicates that the establishment of a PBoC swap line has been associated with greater renminbi invoicing for countries that have higher trade exposure to China.

Figure 13 illustrates the effect of the swap line depending on the trade exposure to China in more detail, showing the impact on invoicing on exports (left column) and imports (right column). The top row shows the impact on renminbi invoicing, whereas the middle and bottom rows show the impact on the use of dollar and euro, respectively. In each panel, the solid line shows the impact of the swap line for the corresponding trade exposure, along with the

\footnotetext{
${ }^{23}$ We run the regressions on data for the period after 2007-i.e. from the year in which the first PBoC swap line was established (see Table A.2) - rather than 2011 as in Tables 3 and 5.
} 
Table 6: The effect of the establishment of PBoC swap lines on renminbi invoicing

\begin{tabular}{|c|c|c|c|c|c|c|}
\hline & \multicolumn{3}{|c|}{ Exports } & \multicolumn{3}{|c|}{ Imports } \\
\hline & (1) & $(2)$ & (3) & (4) & $(5)$ & $(6)$ \\
\hline Swap line with PBoC & $\begin{array}{l}-0.08 \\
(0.37)\end{array}$ & $\begin{array}{c}-0.34^{* * *} \\
(0.01)\end{array}$ & $\begin{array}{c}-0.08 \\
(0.11)\end{array}$ & $\begin{array}{l}-0.01 \\
(0.97)\end{array}$ & $\begin{array}{c}-0.95^{* *} \\
(0.02)\end{array}$ & $\begin{array}{r}-0.77^{* *} \\
(0.03)\end{array}$ \\
\hline $\mathrm{x}$ share of $\mathrm{X} / \mathrm{M}$ accounted for by China & & $\begin{array}{c}0.03^{*} \\
(0.09)\end{array}$ & $\begin{array}{l}-0.00 \\
(0.90)\end{array}$ & & $\begin{array}{c}0.08^{*} \\
(0.06)\end{array}$ & $\begin{array}{l}0.07^{* *} \\
(0.04)\end{array}$ \\
\hline Within R-squared & 0.23 & 0.27 & 0.49 & 0.23 & 0.40 & 0.55 \\
\hline Observations & 240 & 240 & 236 & 292 & 292 & 288 \\
\hline Countries & 38 & 38 & 37 & 49 & 49 & 48 \\
\hline Effect of PBoC swap line for high CHN exposure & & $\begin{array}{c}0.15 \\
(0.43)\end{array}$ & $\begin{array}{c}-0.11 \\
(0.59)\end{array}$ & & $\begin{array}{l}0.82 \\
(0.12)\end{array}$ & $\begin{array}{c}0.77^{* *} \\
(0.05)\end{array}$ \\
\hline
\end{tabular}

Note: The dependent variable is the share of countries' exports (columns (1) to (3)) and imports (columns (4) to (6)) invoiced in renminbi. Inference is based on Driscoll-Kraay robust standard errors. $p$-values are reported in parentheses below the point estimates, and ${ }^{*}\left({ }^{* *}\right)\left[{ }^{* * *}\right]$ indicates statistical significance at the $10 \%(5 \%)[1 \%]$ significance level. Country and time fixed effects are included in all regressions. The coefficient estimates for the share of homogeneous goods in total trade, backward GVC integration, US/EA and US dollar/euroblock trade shares, exchange rates and the aspects related to China's foreign policy are not reported to save space. The last row provides the marginal effects of a PBoC currency swap lines on renminbi invoicing shares, evaluated at a 'high' share of countries' exports to/imports from China. A 'High' share refers to the mean plus one standard deviation of the cross-country distribution of trade shares with China. The associated marginal effects are plotted in the top row of Figure 13.

$90 \%$ confidence bands (dashed lines). The dashed-dotted line shows the kernel density of this exposure across the countries in our sample.

We see that the swap lines foster more use of the renminbi once trade exposure to China reaches a threshold. Clearly, the marginal effect is estimated imprecisely, so that it is statistically significant at best only for rather high values the share of countries' trade with China. Indeed, the last line in Table 6 indicates that for a country that exhibits exposure to China by one standard deviation above the cross-country average, establishing a swap line with the PBoC has been associated with an increase in renminbi invoicing by about 0.2 percentage points in the case of exports and 0.8 percentage points in the case of imports, but that these are not statistically significant at the $10 \%$ significance level.

Reverse causality might be a concern, as it could be that an increase in renminbi invoicing for other reasons leads to the establishment of a swap line due to increased demand for renminbi. However, the time fixed effects we include in the regressions control for common trends in the adoption of the renminbi and in the expansion of the PBoC's currency swap line network across countries. In addition, the cross-sectional fixed effects capture time-invariant factors that make a given country more likely to both use the renminbi in invoicing and establish a swap line with the PBoC.

It could also be that non-trade related capital flows lead to increased renminbi invoicing owing to policies distinct from-but correlated with - the establishment of PBoC swap lines. For instance, the swap lines are often signed as part of a package of joint policies between China and the counterparty country, and it could be that these policies are the ultimate cause for the use of the renminbi in invoicing. To address this issue, as in Bahaj and Reis (2020) as well as Cheung et al. (2021) we enter interactions with four indicators related to China's foreign economic policy, namely whether a country has a renminbi clearing bank, a free trade agreement with China, infrastructure investment flows from China as a ratio of a country's 
Figure 13: Marginal effects of the establishment of PBoC swap lines on invoicing currency patterns
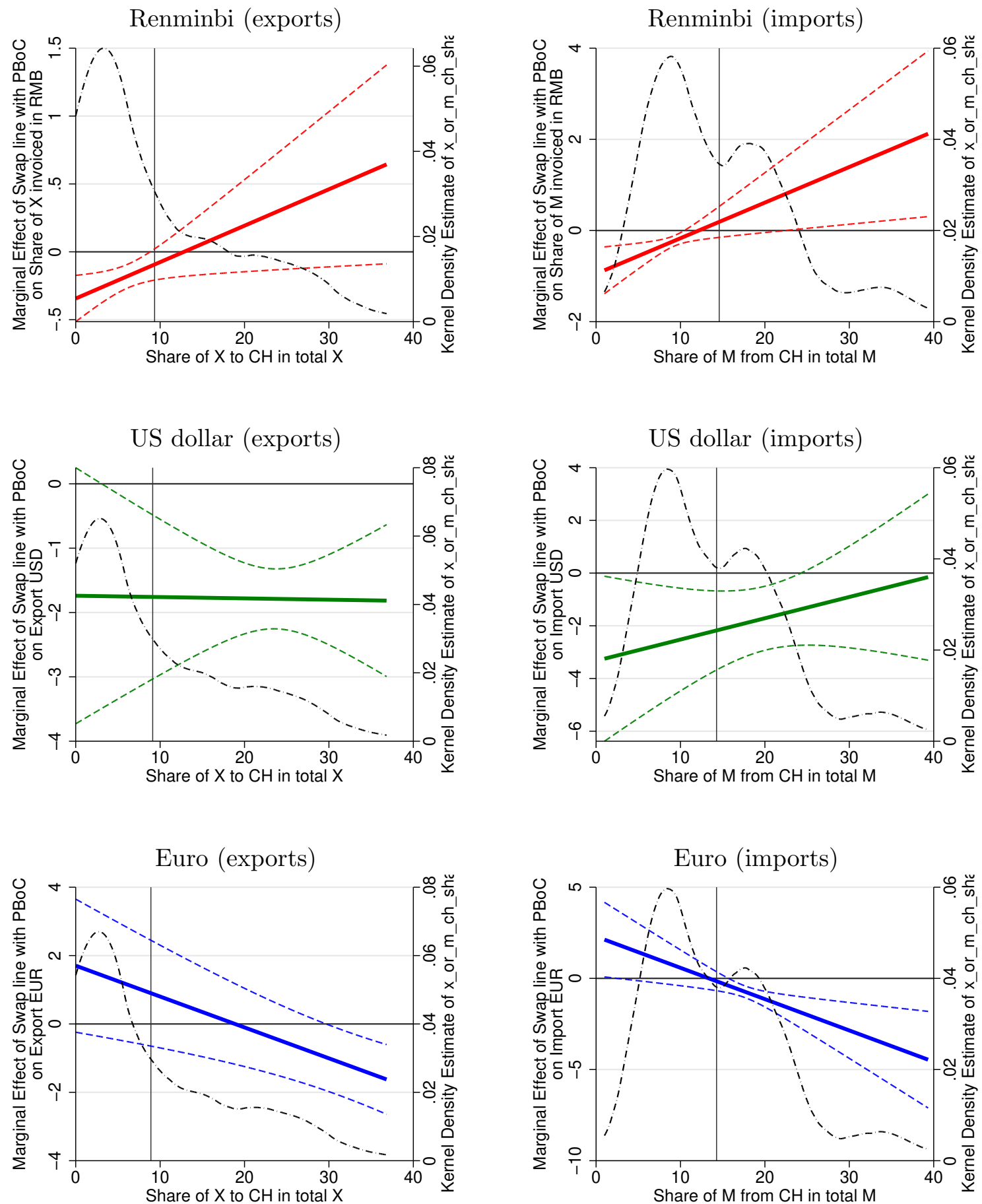

Note: The figure shows the marginal effects of PBoC swap lines on renminbi invoicing from Table 6 (columns (2) and (5)) and Table 7. The results for exports are shown in the left-hand side column, and those for imports in the right-hand side column. The solid line indicates the point estimate, the dashed lines $90 \%$ confidence bands, and the dash-dotted lines kernel density estimates of the distribution of the share of countries' exports/imports with China. 
gross domestic product in order to account for the Belt and Road Initiative, and whether there have been bilateral geopolitical tensions. The estimates are reported in columns (3) and (6) in Table 6. We see that the estimates are robust for the inclusion of these additional controls only for renminbi invoicing of imports, for which they turn out to be more precise. The associated marginal effects are plotted in the top row of Figure B.2.

Finally, we assess whether the positive effect of $\mathrm{PBoC}$ swap lines on renminbi invoicing for countries with high trade exposure to China has occurred at the expense of the dollar and/or the euro. To do so, we run regression analogous to those for the renminbi of Table 6 taking the invoicing share of the dollar, the euro and 'other' currencies as the dependent variables. The results are reported in Table 7, and the corresponding marginal effects for dollar and euro invoicing are shown in the middle and bottom rows of Figure 13.

Table 7: The effects of the establishment of $\mathrm{PBoC}$ swap lines on renminbi invoicing

\begin{tabular}{|c|c|c|c|c|c|c|c|c|}
\hline & \multicolumn{4}{|c|}{ Exports } & \multicolumn{4}{|c|}{ Imports } \\
\hline & (1) & (2) & (3) & (4) & (5) & (6) & (7) & (8) \\
\hline & USD & EUR & RMB & Other & USD & EUR & RMB & Other \\
\hline Swap line with PBoC & $\begin{array}{l}-1.74 \\
(0.18)\end{array}$ & $\begin{array}{c}1.70 \\
(0.18)\end{array}$ & $\begin{array}{c}-0.34^{* * * *} \\
(0.01)\end{array}$ & $\begin{array}{l}-1.03 \\
(0.18)\end{array}$ & $\begin{array}{l}-3.33 \\
(0.12)\end{array}$ & $\begin{array}{c}2.30 \\
(0.11)\end{array}$ & $\begin{array}{c}-0.95^{* *} \\
(0.02)\end{array}$ & $\begin{array}{l}2.10^{*} \\
(0.07)\end{array}$ \\
\hline $\mathrm{x}$ share of $\mathrm{X} / \mathrm{M}$ accounted for by China & $\begin{array}{l}-0.00 \\
(0.97)\end{array}$ & $\begin{array}{c}-0.09^{* *} \\
(0.02)\end{array}$ & $\begin{array}{l}0.03^{*} \\
(0.09)\end{array}$ & $\begin{array}{c}-0.04 \\
(0.40)\end{array}$ & $\begin{array}{c}0.08 \\
(0.40)\end{array}$ & $\begin{array}{c}-0.17^{* *} \\
(0.04)\end{array}$ & $\begin{array}{c}0.08^{*} \\
(0.06)\end{array}$ & $\begin{array}{c}0.01 \\
(0.92)\end{array}$ \\
\hline Within R-squared & 0.39 & 0.38 & 0.27 & 0.11 & 0.27 & 0.36 & 0.40 & 0.19 \\
\hline Observations & 299 & 307 & 240 & 235 & 357 & 357 & 292 & 287 \\
\hline Countries & 38 & 38 & 38 & 37 & 49 & 49 & 49 & 48 \\
\hline Effect of PBoC swap line for high CHN exposure & $\begin{array}{c}-1.78^{* * *} \\
(0.00)\end{array}$ & $\begin{array}{l}0.08 \\
(0.92)\end{array}$ & $\begin{array}{l}0.15 \\
(0.43)\end{array}$ & $\begin{array}{l}-1.84 \\
(0.22)\end{array}$ & $\begin{array}{c}-1.55^{*} \\
(0.06)\end{array}$ & $\begin{array}{c}-1.48^{* * *} \\
(0.00)\end{array}$ & $\begin{array}{l}0.82 \\
(0.12)\end{array}$ & $\begin{array}{l}2.33 \\
(0.14) \\
\end{array}$ \\
\hline
\end{tabular}

Note: The dependent variable is the share of countries' exports/imports invoiced in US dollars (column (1)/(5)), in euros (column $((2) /(6))$, in renminbi (column $((3) /(7))$, and in currencies other than the US dollar, the euro, and the renminbi (column $(4) /(8))$. Inference is based on Driscoll-Kraay robust standard errors. $p$-values are reported in parentheses below the point estimates, and * $\left.\left({ }^{* *}\right)^{[* *}\right]$ indicates statistical significance at the $10 \%(5 \%)$ [1\%] significance level. Country and time fixed effects are included in all regressions. The coefficient estimates for the share of homogeneous goods in total trade, backward GVC integration, US/EA and US dollar/euro-block trade shares as well as exchange rates are not reported to save space. The last row provides the marginal effects of the PBoC's currency swap lines on renminbi invoicing shares, evaluated at a 'high' share of countries' trade with China. A 'high' share refers to the mean plus one standard deviation of the cross-country distribution of trade shares with China. The associated marginal effects are plotted in Figure 13

The results suggest that the increase in renminbi invoicing following the establishment of a swap line (for countries with sufficient trade with China) occurs at the expense of both the euro and the dollar, with the impact on the dollar being larger for export invoicing. In terms of export invoicing, Figure 13 shows that the effect for the dollar is significantly negative irrespective of the country's trade exposure to China. By contrast, the use of the euro is only reduced for countries with substantial trade with China, being instead marginally boosted for countries that do not trade much with China. In terms of imports, swap line reduce the role of the dollar, except for countries with a large share of imports coming from China. The effect on the euro is sensitive to the trade share with China, with a negative effect observed only when the share is high. If we consider a country which is one standard deviation above the cross-country average exposure to China, establishing a swap line is associated with a reduction of import dollar invoicing by about 1.8 percentage points and euro invoicing by about 1.1 percentage points. Table C. 6 provides the corresponding results for the specification in which we additionally control for other dimensions of China's foreign policy as in columns (3) and (6) in Table 6; here only the results for import invoicing currencies - and here only for renminbi and dollars - are robust. Finally, Table C.7 and 
Figure B.3 document that the findings for dollar invoicing do not change substantively when the sample is extended to all countries for which we have data.

Overall, our findings for the relationship between the establishment of a PBoC swap line and invoicing currency choice is reasonably robust, especially for invoicing of imports in renminbi and dollar: the establishment of a PBoC swap line has been associated with an increase in renminbi invoicing at the cost of the dollar.

\section{Conclusion}

Can the US dollar's dominance in global trade be dented? In this paper, we provide evidence that the answer to this question is cautiously positive, and depends both on fundamentals and policies.

The EA's importance for global trade creates strategic complementarities which support use of the euro as an invoicing currency for imports, but primarily in Europe. In turn, this supports use of the euro for exports as a hedge between marginal costs and revenues. We also find that evidence that the emergence of the renminbi as an invoicing currency in countries which trade significantly with China has occurred at the expense of the euro, and contributed to strengthening the dollar's globally dominant role. While the use of the renminbi as an invoicing currency remains limited globally, $\mathrm{PBoC}$ swap lines have been associated with greater renminbi invoicing in trade with countries that have a significant trade exposures to China, in this case at the expense of both the euro and - with more robust evidence - the dollar.

In terms of policy implications, our findings suggest that preserving the EA's openness to trade and the European value chain are critical to preserve the euro's role as an invoicing currency. They also indicate that China's global network of currency swap lines is an effective policy measure to overcome frictions in the use of the renminbi as an invoicing currency. 


\section{References}

Amiti, M., Itskhoki, O., Konings, J., 2020. Dominant Currencies: How Firms Choose Currency Invoicing and Why it Matters. NBER Working Papers 27926.

Asian Development Bank, 2019. Asian Economic Integration Report. Asian Development Bank, Manila.

Bacchetta, P., van Wincoop, E., 2005. A Theory of the Currency Denomination of International Trade. Journal of International Economics 67, 295-319.

Bahaj, S., Reis, R., 2020. Jumpstarting an International Currency. CEPR Discussion Paper 14793.

Batten, J., Szilagyi, P., 2016. The Internationalisation of the RMB: New Starts, Jumps and Tipping Points. Emerging Markets Review 28, 221-238.

Belotti, F., Borin, A., Mancini, M., 2020. icio : Economic Analysis with Inter-Country InputOutput Tables in Stata. World Bank Policy Research Working Paper 9156.

Boz, E., Casas, C., Georgiadis, G., Gopinath, G., Le Mezo, H., Mehl, A., Nguyen, T., 2020. Invoicing Currency Patterns in Global Trade. IMF Working Paper 20/126.

Caballero, R., Farhi, E., Gourinchas, P.O., 2008. An Equilibrium Model of "Global Imbalances" and Low Interest Rates. American Economic Review 98, 358-93.

Chen, X., Cheung, Y.W., 2011. Renminbi Going Global. China \& World Economy 19, 1-18.

Cheung, Y.W., 2015. The Role of Offshore Financial Centers in the Process of Renminbi Internationalization, in: Eichengreen, B., Kawai, M. (Eds.), Renminbi Internationalization: Achievements, Prospects, and Challenges. Washington, DC: Brookings Institution Press.

Cheung, Y.W., Grimm, L., Westermann, F., 2021. The Evolution of Offshore Renminbi Trading: 2016 to 2019. Journal of International Money and Finance 113.

Cheung, Y.W., McCauley, R., Shu, C., 2019. Geographic Spread of Currency Trading: The Renminbi and Other Emerging Market Currencies. China \& World Economy 27, 25-36.

Chinn, M., Frankel, J., 2008. Why the Euro Will Rival the Dollar. International Finance 11, 49-73.

Devereux, M., Engel, C., Storgaard, P., 2004. Endogenous Exchange Rate Pass-through When Nominal Prices Are Set in Advance. Journal of International Economics 63, 263-291.

Devereux, M., Shi, S., 2013. Vehicle Currency. International Economic Review 54, 97-133.

Direction Générale du Trésor, 2018. The Global Network of Central Bank Swap Lines. Trésoreconomics 231.

Duisenberg, W., 1999. The euro has arrived. Speech to the American European Community Association held at De Nederlandsche Bank in Amsterdam, 14 January 1999.

Ehlers, T., Packer, F., Zhu, F., 2016. The Changing Landscape of Renminbi Offshore and Onshore Markets. BIS Quarterly Review .

Eichengreen, B., 2011. The Renminbi As an International Currency. Journal of Policy Modeling $33,723-730$. 
Eichengreen, B., Lombardi, D., 2017. RMBI or RMBR? Is the Renminbi Destined to Become a Global or Regional Currency? Asian Economic Papers 16, 35-59.

Eichengreen, B., Mehl, A., Chitu, L., 2019. How Global Currencies Work: Past, Present, and Future. Princeton University Press.

European Central Bank, 2019. The International Role of the Euro. European Central Bank, Frankfurt.

European Commission, 2018. Towards a Stronger International Role of the Euro. European Commission contribution to the European Council and the Euro Summit, Brussels.

Frankel, J., 2012. Internationalization of the RMB and Historical Precedents. Journal of Economic Integration 27, 329-365.

Fratzscher, M., Mehl, A., 2014. China's Dominance Hypothesis and the Emergence of a Tri-polar Global Currency System. The Economic Journal 124, 1343-1370.

Garcia-Herrero, A., Xia, L., 2015. RMB Bilateral Swap Agreements: How China Chooses its Partners? Asia-Pacific Journal of Accounting \& Economics 22, 368-383.

Goldberg, L., Tille, C., 2008. Vehicle-currency Use in International Trade. Journal of International Economics 76, 177-192.

Goldberg, L., Tille, C., 2013. A Bargaining Theory of Trade Invoicing and Pricing. NBER Working Paper 18985.

Gopinath, G., 2015. The International Price System. NBER Working Paper 21646.

Gopinath, G., Boz, E., Casas, C., Díez, F.J., Gourinchas, P.O., Plagborg-Møller, M., 2020. Dominant currency paradigm. American Economic Review 110, 677-719.

Gopinath, G., Itskhoki, O., Rigobon, R., 2010. Currency Choice and Exchange Rate PassThrough. American Economic Review 100, 304-336.

Gopinath, G., Stein, J., 2021. Banking, trade, and the making of a dominant currency. Quarterly Journal of Economics 136, 83-830.

Gourinchas, P.O., 2019. The Dollar Hegemon? Evidence and Implications for Policy Makers. Prepared for the $6^{\text {th }}$ Asian Monetary Policy Forum to be held in Singapore on 31 May 2019 .

Gourinchas, P.O., Rey, H., 2013. External Adjustment, Global Imbalances and Valuation Effects. NBER Working Paper 19240.

Hallak, J., Schott, P., 2011. Estimating Cross-Country Differences in Product Quality. The Quarterly Journal of Economics 126, 417-474.

Hummels, D., Ishii, J., Yi, K.M., 2001. The Nature and Growth of Vertical Specialization in World Trade. Journal of International Economics 54, 75-96.

Ilzetzki, E., Reinhart, C., Rogoff, K., 2019. Exchange Arrangements Entering the Twenty-First Century: Which Anchor will Hold? Quarterly Journal of Economics 2, 599-646.

Ilzetzki, E., Reinhart, C., Rogoff, K., 2020. Why is the Euro Punching Below its Weight. CEPR Discussion Paper 14315. 
Ito, H., Chinn, M., 2014. The Rise of the "Redback" and the People's Republic of China's Capital Account Liberalization: An Empirical Analysis of the Determinants of Invoicing Currencies. ADBI Working Paper 473.

Ito, H., Kawai, M., 2016. Trade Invoicing in Major Currencies in the 1970s-1990s: Lessons for Renminbi Internationalization. Journal of the Japanese and International Economies 42, $123-145$.

Ito, T., 2017. A New Financial Order in Asia: Will a RMB Bloc Emerge? Journal of International Money and Finance 74, 232-257.

Kamps, A., 2006. The Euro as Invoicing Currency in International Trade. ECB Working Paper 665 .

Lafarguette, R., 2015. Update of Kamps (2006). mimeo.

Lenzen, M., Moran, D., Kanemoto, K., Geschke, A., 2013. Building EORA: A Global MultiRegion Input-Output Database At High Country And Sector Resolution. Economic Systems Research 25, 20-49.

Liao, S., McDowell, D., 2015. Redback Rising: China's Bilateral Swap Agreements and Renminbi Internationalization. International Studies Quarterly 59, 401-422.

Lin, Z., Zhan, W., Cheung, Y.W., 2016. China's Bilateral Currency Swap Lines. China \& World Economy 24, 19-42.

Maggiori, M., Neiman, B., Schreger, J., 2019. The Rise of the Dollar and Fall of the Euro as International Currencies. AEA Papers and Proceedings 109, 521-526.

McDowell, D., 2019. The (Ineffective) Financial Statecraft of China's Bilateral Swap Agreements. Development and Change 50, 122-143.

Miranda-Agrippino, S., Rey, H., 2020. US Monetary Policy and the Global Financial Cycle. Review of Economic Studies 87, 2754-2776.

Mukhin, D., 2021. An Equilibrium Model of the International Price System. mimeo .

Murray, J., Powell, J., 2002. Dollarization in Canada: The Buck Stops There. Bank of Canada Technical Report 90.

Novy, D., 2006. Hedge Your Costs: Exchange Rate Risk and Endogenous Currency Invoicing. Warwick Economics Research Paper 765.

Panetta, F., 2020. Sharing and Strengthening the Euro's Privilege. The ECB Blog.

People's Bank of China, 2011. The PBoC Annual Report 2010. People's Bank of China, Beijing.

People's Bank of China, 2012. The PBoC Annual Report 2011. People's Bank of China, Beijing.

People's Bank of China, 2015. The Report of RMB Internationalisation. People's Bank of China, Beijing.

Portes, R., Rey, H., 1998. The Emergence of the Euro as an International Currency. Economic Policy 13, 305-343.

Prasad, E., 2016. Gaining Currency: The Rise of the Renminbi. Oxford University Press. 
Rauch, J., 1999. Networks Versus Markets in International Trade. Journal of International Economics 48, 7-35.

Rey, H., 2001. International Trade and Currency Exchange. Review of Economic Studies 68, $443-464$.

Song, K., Xia, L., 2019. Bilateral Swap Agreement and Renminbi Settlement in Cross-border Trade. BOFIT Discussion Paper 19/2019.

Timmer, M., Dietzenbacher, E., Los, B., Stehrer, R., Vries, G., 2015. An Illustrated User Guide to the World Input-Output Database: The Case of Global Automotive Production. Review of International Economics 23, 575-605. 


\section{A Additional Tables}

Table A.1: Invoicing currency data overview

\begin{tabular}{|c|c|c|c|c|c|}
\hline Country & Code & Range & Type & Source & Comment \\
\hline \multicolumn{6}{|l|}{ North Africa } \\
\hline Algeria & DZA & 2001-10 & invoicing & Customs Authority & $\begin{array}{l}\text { Exports only for } 2003-04 ; 2001 \\
\text { for euro not available due to } \\
\text { lack of legacy currency infor- } \\
\text { mation from Lafarguette (2015) } \\
(2003-2004 \text { Exports; Imports: } \\
2001-2010)\end{array}$ \\
\hline Egypt & EGY & 2010-19 & invoicing & Central Bank of Egypt & \\
\hline Morocco & MAR & $2006-16$ & invoicing & $\begin{array}{l}\text { Ministry of Planning and } \\
\text { Economics }\end{array}$ & \\
\hline Tunisia & TUN & $\begin{array}{l}1995-2001, \quad 2010- \\
19\end{array}$ & invoicing & $\begin{array}{l}\text { Banque Centrale de } \\
\text { Tunisie }\end{array}$ & $\begin{array}{l}\text { 1995-2001 from Kamps (2006), } \\
\text { US dollar data until 2018, euro } \\
\text { data until } 2019\end{array}$ \\
\hline \multicolumn{6}{|l|}{ Sub-Saharan Africa } \\
\hline Angola & AGO & 2016-19 & invoicing & National Bank of Angola & \\
\hline Benin & BEN & 2016-19 & invoicing & $\begin{array}{l}\text { Central Bank of West } \\
\text { African Currency Union }\end{array}$ & $\begin{array}{l}\text { Data part of the West African } \\
\text { Currency Union aggregate ex- } \\
\text { cluding Cote d'Ivoire and Sene- } \\
\text { gal }\end{array}$ \\
\hline Botswana & BWA & 2003-19 & invoicing & Statistics Botswana & \\
\hline Burkina Faso & BFA & 2016-19 & invoicing & $\begin{array}{l}\text { Central Bank of West } \\
\text { African Currency Union }\end{array}$ & $\begin{array}{l}\text { Data part of the West African } \\
\text { Currency Union aggregate ex- } \\
\text { cluding Cote d'Ivoire and Sene- } \\
\text { gal }\end{array}$ \\
\hline Cote d'Ivoire & CIV & 2016-19 & invoicing & $\begin{array}{l}\text { Central Bank of West } \\
\text { African Currency Union }\end{array}$ & \\
\hline $\begin{array}{l}\text { Democratic Re- } \\
\text { public of Congo }\end{array}$ & $\mathrm{COD}$ & 2014-19 & invoicing & Banque Centrale du Congo & \\
\hline Eswatini & SWZ & 2016-18 & invoicing & Central Bank of Eswatini & \\
\hline Ghana & GHA & 2017-19 & settlement & Bank of Ghana & \\
\hline Gambia & GMB & $2012-16$ & invoicing & $\begin{array}{l}\text { Central Bank of The Gam- } \\
\text { bia, Gambia Revenue Au- } \\
\text { thority }\end{array}$ & only exports \\
\hline Guinea-Bissau & GNB & 2016-19 & invoicing & $\begin{array}{l}\text { Central Bank of West } \\
\text { African Currency Union }\end{array}$ & $\begin{array}{l}\text { Data part of the West African } \\
\text { Currency Union aggregate ex- } \\
\text { cluding Cote d'Ivoire and Sene- } \\
\text { gal }\end{array}$ \\
\hline Liberia & LBR & 2000-19 & invoicing & Central Bank of Liberia & $\begin{array}{l}\text { Liberian trade invoiced exclu- } \\
\text { sively in US dollars according to } \\
\text { Central Bank of Liberia. We as- } \\
\text { sume such practice has been the } \\
\text { case since } 2000\end{array}$ \\
\hline Madagascar & MDG & $2015-18$ & invoicing & $\begin{array}{l}\text { Banque Centrale de Mada- } \\
\text { gascar }\end{array}$ & \\
\hline Malawi & MWI & 2014-19 & settlement & Reserve Bank of Malawi & \\
\hline Mali & MLI & 2016-19 & invoicing & $\begin{array}{l}\text { Central Bank of West } \\
\text { African Currency Union }\end{array}$ & $\begin{array}{l}\text { Data part of the West African } \\
\text { Currency Union aggregate ex- } \\
\text { cluding Cote d'Ivoire and Sene- } \\
\text { gal }\end{array}$ \\
\hline Mauritius & MUS & 2009-19 & invoicing & Bank of Mauritius & \\
\hline Mozambique & MOZ & 2011-19 & invoicing & Banco de Moçambique & \\
\hline Namibia & NAM & 2017-19 & settlement & Bank of Namibia & \\
\hline Niger & NER & 2016-19 & invoicing & $\begin{array}{l}\text { Central Bank of West } \\
\text { African Currency Union }\end{array}$ & $\begin{array}{l}\text { Data part of the West African } \\
\text { Currency Union aggregate ex- } \\
\text { cluding Cote d'Ivoire and Sene- } \\
\text { gal }\end{array}$ \\
\hline Rwanda & RWA & 2019 & invoicing & $\begin{array}{l}\text { National Bank of Rwanda, } \\
\text { Rwanda Customs }\end{array}$ & \\
\hline Senegal & SEN & 2016-19 & invoicing & $\begin{array}{l}\text { Central Bank of West } \\
\text { African Currency Union }\end{array}$ & \\
\hline Seychelles & SYC & 2015-19 & invoicing & Central Bank of Seychelles & Only imports \\
\hline South Africa & $\mathrm{ZAF}$ & $2003,2017-19$ & invoicing & $\begin{array}{llr}\text { South Africa } & \text { Treasury, } \\
\text { South African } & \text { Revenue } \\
\text { Service } & & \end{array}$ & $\begin{array}{l}2003 \text { from Kamps (2006); only } \\
\text { exports }\end{array}$ \\
\hline Tanzania & TZA & 2015-19 & invoicing & Bank of Tanzania & \\
\hline Togo & TGO & 2016-19 & invoicing & $\begin{array}{l}\text { Central Bank of West } \\
\text { African Currency Union }\end{array}$ & $\begin{array}{l}\text { Data part of the West African } \\
\text { Currency Union aggregate ex- } \\
\text { cluding Cote d'Ivoire and Sene- } \\
\text { gal }\end{array}$ \\
\hline Uganda & UGA & 2015-19 & invoicing & $\begin{array}{l}\text { Uganda Revenue Author- } \\
\text { ity }\end{array}$ & only imports \\
\hline
\end{tabular}

Note: "A1" refers to trade with the rest of the world, "J6" to trade with non-euro area countries, and "V2" to trade with non-EU countries. When data for more than one concept is available for the same time period, priority is given to the A1 series, followed by the J6 series and lastly the V2 series. In these cases, J6 and V2 series are adjusted to refer to trade with the rest of the world assuming that a certain share of intra-EU and intra-euro area trade is invoiced in euros, typically $90 \%$ for euro area countries and $60 \%$ for non-euro area $E U$ countries. When data are available for different concepts for Z39ferent, non-overlapping time periods, we perform "continuationadjustment". In particular, we adjust the V2/J6 series by assuming a euro invoicing share for intra-EU trade such that the transition between the time series is smooth. Finally, when data are available for overlapping time periods but also cover different sub-periods we backpolate and extrapolate based on actual changes, again giving priority to A1, J6 and then V2. 
Table A.1: Invoicing currency data overview (continued)

\begin{tabular}{|c|c|c|c|c|c|}
\hline Centeduntiny & Code & Range & Type & Source & Comment \\
\hline Armenia & ARM & $2015-19$ & invoicing & $\begin{array}{l}\text { Armenia State Revenue } \\
\text { Commitee }\end{array}$ & \\
\hline Azerbaijan & $\mathrm{AZE}$ & 2012-19 & invoicing & $\begin{array}{l}\text { Central Bank of Azerbai- } \\
\text { jan }\end{array}$ & \\
\hline Georgia & GEO & 2015-19 & invoicing & National Bank Of Georgia & \\
\hline Kazakhstan & KAZ & 2013-19 & settlement & $\begin{array}{l}\text { Eurasian Economic Com- } \\
\text { mission }\end{array}$ & \\
\hline Kyrgyz Republic & KGZ & 2013-19 & settlement & $\begin{array}{l}\text { Eurasian Economic Com- } \\
\text { mission, National Bank of } \\
\text { Kyrgyz Republic }\end{array}$ & \\
\hline Uzbekistan & UZB & 2018-19 & settlement & $\begin{array}{l}\text { Central Bank of the Re- } \\
\text { public of Uzbekistan }\end{array}$ & \\
\hline \multicolumn{6}{|l|}{ South Asia } \\
\hline$\overline{\text { Bangladesh }}$ & BGD & 2014-19 & settlement & $\begin{array}{l}\text { Bangladesh Bank and } \\
\text { Bangladesh Export Pro- } \\
\text { cessing Zones Authority }\end{array}$ & \\
\hline India & IND & $\begin{array}{l}\text { 1991-2000, 2005, } \\
2008-14\end{array}$ & invoicing & Reserve Bank of India & $\begin{array}{l}\text { Invoicing shares are recorded } \\
\text { from June to June, hence not } \\
\text { clearly attributable to a sin- } \\
\text { gle year; 1991-2000, 2005, } 2008 \\
\text { from Lafarguette }(2015)\end{array}$ \\
\hline Maldives & MDV & $2017-20$ & invoicing & Maldives Customs Service & \\
\hline Nepal & NPL & 2015-20 & invoicing & Nepal Rastra Bank & \\
\hline \multicolumn{5}{|l|}{ South East Asia } & Kamps (2006) \\
\hline Cambodia & KHM & 2015-19 & settlement & $\begin{array}{l}\text { National Bank of Cambo- } \\
\text { dia }\end{array}$ & \\
\hline Indonesia & IDN & $1991,1994-19$ & invoicing & Bank Indonesia & $\begin{array}{l}\text { 1991, 1994-2004 from Kamps } \\
(2006)\end{array}$ \\
\hline Malaysia & MYS & $\begin{array}{l}1995-96 \\
2019\end{array}$ & $\begin{array}{l}\text { invoicing, } \\
\text { settlement }\end{array}$ & $\begin{array}{l}\text { Treasury Malaysia, Bank } \\
\text { Negara Malaysia }\end{array}$ & $\begin{array}{l}\text { invoicing data for } 1995-96 \text { from } \\
\text { Kamps (2006), settlement data } \\
\text { for 2013-2019 from Bank Ne- } \\
\text { gara Malaysia }\end{array}$ \\
\hline Philippines & PHL & 2014-2019 & settlement & $\begin{array}{l}\text { Bangko Sentral ng Pilip- } \\
\text { inas }\end{array}$ & \\
\hline Thailand & THA & 1993-2019 & invoicing & Bank of Thailand & \\
\hline Timor-Leste & TLS & 2002-2019 & invoicing & $\begin{array}{l}\text { Banco Central de Timor- } \\
\text { Leste }\end{array}$ & $\begin{array}{l}\text { Trade invoiced exclusively in } \\
\text { US dollars according to the } \\
\text { Banco Central de Timor-Leste }\end{array}$ \\
\hline \multicolumn{6}{|l|}{ East Asia } \\
\hline Japan & JPN & $\begin{array}{l}1990-1998, \quad 2000- \\
18\end{array}$ & invoicing & Japan Customs & $\begin{array}{l}\text { US dollar shares for 1990-1998 } \\
\text { from Lafarguette (2015) }\end{array}$ \\
\hline Macao & MAC & 2015-19 & invoicing & $\begin{array}{l}\text { Monetary Authority of } \\
\text { Macao }\end{array}$ & \\
\hline Mongolia & MNG & 2006-19 & invoicing & Central Bank of Mongolia & \\
\hline South Korea & KOR & $1990,1992-2019$ & settlement & Statistics Korea & 1990 from Lafarguette (2015) \\
\hline Taiwan & TWN & 2016-19 & invoicing & $\begin{array}{l}\text { Taiwan Customs Adminis- } \\
\text { tration }\end{array}$ & \\
\hline \multicolumn{6}{|l|}{ Middle East } \\
\hline Israel & ISR & $\begin{array}{l}1999-2002, \quad 2004- \\
2007,2010,2012- \\
2019\end{array}$ & invoicing & $\begin{array}{l}\text { Israel Central Bureau of } \\
\text { Statistics }\end{array}$ & \\
\hline Jordan & JOR & 2018-19 & invoicing & Jordan Customs & \\
\hline Kuwait & KWT & 2013-19 & settlement & Central Bank of Kuwait & \\
\hline Saudi Arabia & SAU & 2018-19 & invoicing & $\begin{array}{l}\text { General Authority for } \\
\text { Statistics }\end{array}$ & \\
\hline Turkey & TUR & $1996-2018$ & invoicing & $\begin{array}{l}\text { Turkish Statistical Insti- } \\
\text { tute }\end{array}$ & \\
\hline \multicolumn{6}{|l|}{ Europe } \\
\hline$\overline{\text { Albania }}$ & ALB & 2010-19 & invoicing & Central Bank of Albania & \\
\hline Austria & AUT & $\begin{array}{l}2006, \quad 2008-14, \\
2016-19\end{array}$ & invoicing & $\begin{array}{l}\mathrm{ECB} \text {, nat. authorities, Eu- } \\
\text { rostat }\end{array}$ & \\
\hline Belarus & BLR & 2015-19 & invoicing & $\begin{array}{l}\text { National Statistical Com- } \\
\text { mittee }\end{array}$ & $\begin{array}{l}\text { We also have settlement data } \\
\text { for 2013-19 from Eurasian Eco- } \\
\text { nomic Commission, but they } \\
\text { differ from the invoicing data } \\
\text { for US dollar imports }\end{array}$ \\
\hline Belgium & BEL & $2000-12,2014-19$ & invoicing & ECB, nat. authorities & \\
\hline $\begin{array}{ll}\text { Bosnia and } \\
\text { Herzegovina }\end{array}$ & $\mathrm{BIH}$ & 2010-19 & invoicing & $\begin{array}{l}\text { Central Bank of Bosnia } \\
\text { and Herzegovina }\end{array}$ & \\
\hline Bulgaria & BGR & $\begin{array}{l}1999-2016, \quad 2018- \\
19\end{array}$ & $\begin{array}{l}\text { invoicing and } \\
\text { settlement }\end{array}$ & $\begin{array}{l}\mathrm{ECB} \text {, nat. authorities, Eu- } \\
\text { rostat }\end{array}$ & 1998 from Lafarguette (2015) \\
\hline Croatia & HRV & $\begin{array}{l}1998-14, \quad 2016, \\
2018\end{array}$ & invoicing & $\begin{array}{l}\mathrm{ECB} \text {, nat. authorities, Eu- } \\
\text { rostat }\end{array}$ & $\begin{array}{l}\text { 1998-2000 from Lafarguette } \\
(2015)\end{array}$ \\
\hline Cyprus & CYP & 2003-14, 2016-19 & invoicing & $\begin{array}{l}\mathrm{ECB} \text {, nat. authorities, Eu- } \\
\text { rostat }\end{array}$ & \\
\hline
\end{tabular}

Note: "A1" refers to trade with the rest of the world, "J6" to trade with non-euro area countries, and "V2" to trade with non-EU countries. When data for more than one concept is available for the same time period, priority is given to the A1 series, followed by the J6 series and lastly the V2 series. In these cases, J6 and V2 series are adjusted to refer to trade with the rest of the world assuming that a certain share of intra-EU and intra-euro area trade is invoiced in euros, typically $90 \%$ for euro area countries and $60 \%$ for non-euro area $E U$ countries. When data are available for different concepts for Zifferent, non-overlapping time periods, we perform "continuationadjustment". In particular, we adjust the V2/J6 series by assuming a euro invoicing share for intra-EU trade such that the transition between the time series is smooth. Finally, when data are available for overlapping time periods but also cover different sub-periods we backpolate and extrapolate based on actual changes, again giving priority to A1, J6 and then V2. 
Table A.1: Invoicing currency data overview (continued)

\begin{tabular}{|c|c|c|c|c|c|}
\hline Country & Code & Range & Type & Source & Comment \\
\hline Czech Republic & $\mathrm{CZE}$ & 1999-2019 & invoicing & ECB, nat. authorities & \\
\hline Denmark & DNK & $\begin{array}{l}1999-2004,2010 \\
2012,2014,2016 \\
2018\end{array}$ & invoicing & $\begin{array}{l}\mathrm{ECB} \text {, nat. authorities, Eu- } \\
\text { rostat }\end{array}$ & \\
\hline Estonia & EST & $\begin{array}{l}1999-2014, \quad 2016- \\
19\end{array}$ & invoicing & $\begin{array}{l}\mathrm{ECB} \text {, nat. authorities, Eu- } \\
\text { rostat }\end{array}$ & \\
\hline Finland & FIN & $\begin{array}{l}2006,2010,2012 \\
2014,2016-19\end{array}$ & invoicing & $\begin{array}{l}\mathrm{ECB} \text {, nat. authorities, Eu- } \\
\text { rostat }\end{array}$ & \\
\hline France & FRA & 1999-2019 & invoicing & ECB, nat. authorities & \\
\hline Germany & DEU & 2002-07, 2009-19 & invoicing & $\begin{array}{l}\mathrm{ECB} \text {, nat. authorities, Eu- } \\
\text { rostat }\end{array}$ & \\
\hline Greece & GRC & 2001-19 & invoicing & ECB, nat. authorities & \\
\hline Hungary & HUN & $\begin{array}{l}1992-2014, \quad 2016- \\
19\end{array}$ & invoicing & $\mathrm{ECB}$, nat. authorities & \\
\hline Iceland & ISL & $1998-2019$ & invoicing & Statistics Iceland & \\
\hline Ireland & IRL & 2006-14, 2016-19 & invoicing & $\begin{array}{l}\mathrm{ECB} \text {, nat. authorities, Eu- } \\
\text { rostat }\end{array}$ & \\
\hline Italy & ITA & $\begin{array}{l}2001-12, \quad 2014, \\
2016\end{array}$ & $\begin{array}{l}\text { settlement } \\
\text { before } 2010, \\
\text { invoicing } \\
\text { after } 2010\end{array}$ & $\begin{array}{l}\mathrm{ECB} \text {, nat. authorities, Eu- } \\
\text { rostat }\end{array}$ & \\
\hline Latvia & LVA & 2000-19 & invoicing & $\mathrm{ECB}$, nat. authorities & \\
\hline Lithuania & LTU & 1999-2019 & invoicing & ECB, nat. authorities & \\
\hline Luxembourg & LUX & 2000-14, 2016-19 & invoicing & $\begin{array}{l}\mathrm{ECB}, \text { nat. authorities, Eu- } \\
\text { rostat }\end{array}$ & \\
\hline Malta & MLT & $\begin{array}{l}2010,2012,2014 \\
2016,2018-19\end{array}$ & invoicing & Eurostat & \\
\hline Moldova & MDA & $2017-18$ & invoicing & National Bank of Moldova & $\begin{array}{l}\text { We also have settlement data } \\
\text { for 2014- } 18 \text { from National Bank } \\
\text { of Moldova, but they differ from } \\
\text { the invoicing data for US dollar } \\
\text { and euro exports }\end{array}$ \\
\hline Montenegro & MNE & 2010-19 & settlement & $\begin{array}{l}\text { Central Bank of Montene- } \\
\text { gro }\end{array}$ & \\
\hline Netherlands & NLD & $\begin{array}{l}1998-2002, \quad 2006 \\
2010,2012,2014 \\
2016,2018-19\end{array}$ & invoicing & $\begin{array}{l}\mathrm{ECB} \text {, nat. authorities, Eu- } \\
\text { rostat }\end{array}$ & \\
\hline $\begin{array}{l}\text { Northern Mace- } \\
\text { donia }\end{array}$ & MKD & $1998-17$ & invoicing & State Statistical Office & $\begin{array}{l}\text { 1998-2001 from Kamps (2006), } \\
2002-2012 \text { from Lafarguette } \\
(2015)\end{array}$ \\
\hline Norway & NOR & $1999-18$ & invoicing & Statistics Norway & \\
\hline Poland & POL & $\begin{array}{l}1994-2010, \quad 2012 \\
2014,2016-19\end{array}$ & invoicing & $\begin{array}{l}\mathrm{ECB} \text {, nat. authorities, Eu- } \\
\text { rostat }\end{array}$ & \\
\hline Portugal & PRT & 2000-19 & invoicing & ECB, nat. authorities & \\
\hline Romania & ROU & 1999-2019 & invoicing & $\mathrm{ECB}$, nat. authorities & \\
\hline Russia & RUS & 2008-19 & settlement & Central Bank of Russia & \\
\hline Serbia & SRB & 2002-03, 2007-19 & invoicing & National Bank of Serbia & $\begin{array}{l}\begin{array}{l}2002-03 \\
(2015)\end{array} \text { from } \quad \text { Lafarguette } \\
\end{array}$ \\
\hline Slovenia & SVN & $\begin{array}{l}2000-01,2003-14 \\
2016-19\end{array}$ & invoicing & $\begin{array}{l}\mathrm{ECB}, \text { nat. authorities, Eu- } \\
\text { rostat }\end{array}$ & \\
\hline Slovakia & SVK & $1999-2019$ & invoicing & ECB, nat. authorities & \\
\hline Spain & ESP & $\begin{array}{l}1998-2014, \quad 2016- \\
18\end{array}$ & invoicing & $\begin{array}{l}\mathrm{ECB} \text {, nat. authorities, Eu- } \\
\text { rostat }\end{array}$ & \\
\hline Sweden & SWE & 2010-19 & invoicing & ECB, nat. authorities & \\
\hline Switzerland & $\mathrm{CHE}$ & 2012-19 & invoicing & $\begin{array}{l}\text { Federal Customs Adminis- } \\
\text { tration }\end{array}$ & \\
\hline Ukraine & UKR & 2001-04, 2006-19 & settlement & National Bank of Ukraine & $\begin{array}{l}\text { 2001-04 taken from Lafarguette } \\
\text { (2015); we also have invoic- } \\
\text { ing data for 2015-19 from State } \\
\text { Customs Service of Ukraine }\end{array}$ \\
\hline United Kingdom & GBR & $\begin{array}{l}1999-2002, \quad 2010- \\
18\end{array}$ & invoicing & $\begin{array}{l}\text { ECB, nat. authorities, } \\
\text { Eurostat, HM Revenue \& } \\
\text { Customs }\end{array}$ & \\
\hline \multicolumn{6}{|l|}{ Oceania } \\
\hline$\overline{\text { Australia }}$ & AUS & $1997-2016$ & invoicing & $\begin{array}{l}\text { Australian Bureau of } \\
\text { Statistics }\end{array}$ & \\
\hline Fiji & FJI & 2016-19 & invoicing & $\begin{array}{l}\text { Fiji Revenue and Customs } \\
\text { Services }\end{array}$ & \\
\hline New Zealand & NZL & 2004-19 & invoicing & Stats NZ & \\
\hline Solomon Islands & SLB & 2015-19 & settlement & $\begin{array}{l}\text { Central Bank of Solomon } \\
\text { Islands }\end{array}$ & Only US dollar \\
\hline \multicolumn{6}{|c|}{ Latin America and Caribbean } \\
\hline Argentina & ARG & 2010-19 & invoicing & National Institute of & \\
\hline Bahamas & BHS & $2009-18$ & invoicing & $\begin{array}{l}\text { Central Bank of The Ba- } \\
\text { hamas }\end{array}$ & \\
\hline
\end{tabular}

Note: "A1" refers to trade with the rest of the world, "J6" to trade with non-euro area countries, and "V2" to trade with non-EU countries. When data for more than one concept is available for the same time period, priority is given to the A1 series, followed by the J6 series and lastly the V2 series. In these cases, J6 and V2 series are adjusted to refer to trade with the rest of the world assuming that a certain share of intra-EU and intra-euro area trade is invoiced in euros, typically $90 \%$ for euro area countries and $60 \%$ for non-euro area $E U$ countries. When data are available for different concepts for Zifferent, non-overlapping time periods, we perform "continuationadjustment". In particular, we adjust the V2/J6 series by assuming a euro invoicing share for intra-EU trade such that the transition between the time series is smooth. Finally, when data are available for overlapping time periods but also cover different sub-periods we backpolate and extrapolate based on actual changes, again giving priority to A1, J6 and then V2. 
Table A.1: Invoicing currency data overview (continued)

\begin{tabular}{|c|c|c|c|c|c|}
\hline Country & Code & Range & Type & Source & Comment \\
\hline Belize & BLZ & $2000-19$ & invoicing & Central Bank of Belize & for exports only $2017-19$ \\
\hline Brazil & BRA & $2000-12,2017-18$ & $\begin{array}{l}\text { settlement, } \\
\text { invoicing }\end{array}$ & $\begin{array}{l}\text { Banco Central do Brasil, } \\
\text { Ministry of Foreign Trade }\end{array}$ & $\begin{array}{l}\text { Data for 2000-12 from Lafar- } \\
\text { guette }(2015)\end{array}$ \\
\hline Chile & $\mathrm{CHL}$ & 2004-19 & invoicing & Chile Customs & \\
\hline Colombia & $\mathrm{COL}$ & $2007-18$ & invoicing & Banco de la República & Exports only \\
\hline Costa Rica & CRI & 2005-19 & invoicing & $\begin{array}{l}\text { Banco Central de Costa } \\
\text { Rica, Direccion General de } \\
\text { Aduanas }\end{array}$ & \\
\hline Ecuador & $\mathrm{ECU}$ & 2015-19 & invoicing & $\begin{array}{l}\text { Banco Central del } \\
\text { Ecuador, National Cus- } \\
\text { toms Service of Ecuador }\end{array}$ & \\
\hline Guyana & GUY & 2019 & invoicing & $\begin{array}{l}\text { Guyana Revenue Author- } \\
\text { ity }\end{array}$ & only imports \\
\hline Paraguay & PRY & 2014-2019 & invoicing & Customs & \\
\hline Peru & PER & $2009-18$ & invoicing & $\begin{array}{l}\text { Banco Central de Reserva } \\
\text { del Peru }\end{array}$ & Only imports \\
\hline Suriname & SUR & 2010-19 & invoicing & Central Bank of Suriname & \\
\hline Uruguay & URY & 2015-19 & invoicing & $\begin{array}{l}\text { Customs Authority of } \\
\text { Uruguay }\end{array}$ & \\
\hline \multicolumn{6}{|l|}{ North America } \\
\hline Canada & $\mathrm{CAN}$ & 2001 & invoicing & Murray and Powell (2002) & $\begin{array}{l}\text { from Kamps (2006), only US } \\
\text { dollar exports }\end{array}$ \\
\hline United States & USA & $2003-18$ & invoicing & $\begin{array}{l}\text { Bureau of Labour Statis- } \\
\text { tics }\end{array}$ & \\
\hline
\end{tabular}

Note: "A1" refers to trade with the rest of the world, "J6" to trade with non-euro area countries, and "V2" to trade with non-EU countries. When data for more than one concept is available for the same time period, priority is given to the A1 series, followed by the J6 series and lastly the V2 series. In these cases, J6 and V2 series are adjusted to refer to trade with the rest of the world assuming that a certain share of intra-EU and intra-euro area trade is invoiced in euros, typically $90 \%$ for euro area countries and $60 \%$ for non-euro area $E U$ countries. When data are available for different concepts for different, non-overlapping time periods, we perform "continuationadjustment". In particular, we adjust the V2/J6 series by assuming a euro invoicing share for intra-EU trade such that the transition between the time series is smooth. Finally, when data are available for overlapping time periods but also cover different sub-periods we backpolate and extrapolate based on actual changes, again giving priority to A1, J6 and then V2. 
Table A.2: List of People's Bank of China renminbi swap lines

\begin{tabular}{|c|c|c|c|}
\hline Country & Date first signed & Notional amount (RMB bil.) & RMB invoicing data since \\
\hline South Korea & $12 / 2008$ & 180 & 1995 \\
\hline Hong Kong & $1 / 2009$ & 200 & \\
\hline Malaysia & $2 / 2009$ & 80 & 2013 \\
\hline Argentina & $3 / 2009$ & 70 & 2010 \\
\hline Belarus & $3 / 2009$ & 20 & 2015 (only imports) \\
\hline Indonesia & $3 / 2009$ & 100 & 2014 imports, 2011 exports \\
\hline Iceland & $6 / 2010$ & 3.5 & 2007 \\
\hline Singapore & $7 / 2010$ & 150 & \\
\hline New Zealand & $4 / 2011$ & 25 & 2003 exports, 2017 imports \\
\hline Uzbekistan & $4 / 2011$ & 0.7 & 2018 (only imports) \\
\hline Mongolia & $5 / 2011$ & 5 & 2006 \\
\hline Kazakhstan & $6 / 2011$ & 7 & \\
\hline Pakistan & $12 / 2011$ & 10 & \\
\hline Thailand & $12 / 2011$ & 70 & 2015 \\
\hline United Arab Emirates & $1 / 2012$ & 35 & \\
\hline Turkey & $2 / 2012$ & 10 & 2012 imports, 2014 exports \\
\hline Australia & $3 / 2012$ & 200 & 2012 \\
\hline Ukraine & $6 / 2012$ & 15 & 2015 \\
\hline Brazil & $3 / 2013$ & 190 & \\
\hline United Kingdom & $6 / 2013$ & 200 & \\
\hline Albania & $9 / 2013$ & 2 & 2010 \\
\hline Hungary & $9 / 2013$ & 10 & \\
\hline Euro area & $10 / 2013$ & 350 & \\
\hline Switzerland & $7 / 2014$ & 150 & \\
\hline Sri Lanka & $9 / 2014$ & 10 & \\
\hline Russia & $10 / 2014$ & 150 & \\
\hline Canada & $11 / 2014$ & 200 & \\
\hline Qatar & $11 / 2014$ & 35 & \\
\hline Nepal & $12 / 2014$ & n.a. & 2015 \\
\hline Armenia & $3 / 2015$ & 1 & 2015 (only imports) \\
\hline Suriname & $3 / 2015$ & 1 & 2010 \\
\hline South Africa & $4 / 2015$ & 30 & \\
\hline Chile & $5 / 2015$ & 22 & 2010 imports, 2013 exports \\
\hline Georgia & $9 / 2015$ & n.a. & 2010 \\
\hline Tajikistan & $12 / 2015$ & 3 & \\
\hline Morocco & $5 / 2016$ & 10 & \\
\hline Serbia & $6 / 2016$ & 1.5 & 2007 \\
\hline Egypt & $12 / 2016$ & 18 & \\
\hline Nigeria & $5 / 2018$ & 15 & \\
\hline Japan & $10 / 2018$ & 200 & 2013 \\
\hline Macao & $12 / 2019$ & 20 & 2000 \\
\hline
\end{tabular}

Note: The table lists the People's Bank of China's renminbi swap lines. The data is taken from Direction Générale du Trésor (2018) as well as Bahaj and Reis (2020), augmented by Nepal and Georgia for which amounts were not disclosed, as well as Macao. For the regressions, we code the dummy variable indicator as unity for a given year when the swap line was first signed until June of that year. We do not consider whether the swap line has expired and/or whether it has been renewed. 


\section{B Additional figures}

Figure B.1: Average levels of backward GVC integration and share of homogeneous goods in total exports for different values of export exposure to the EA and the US
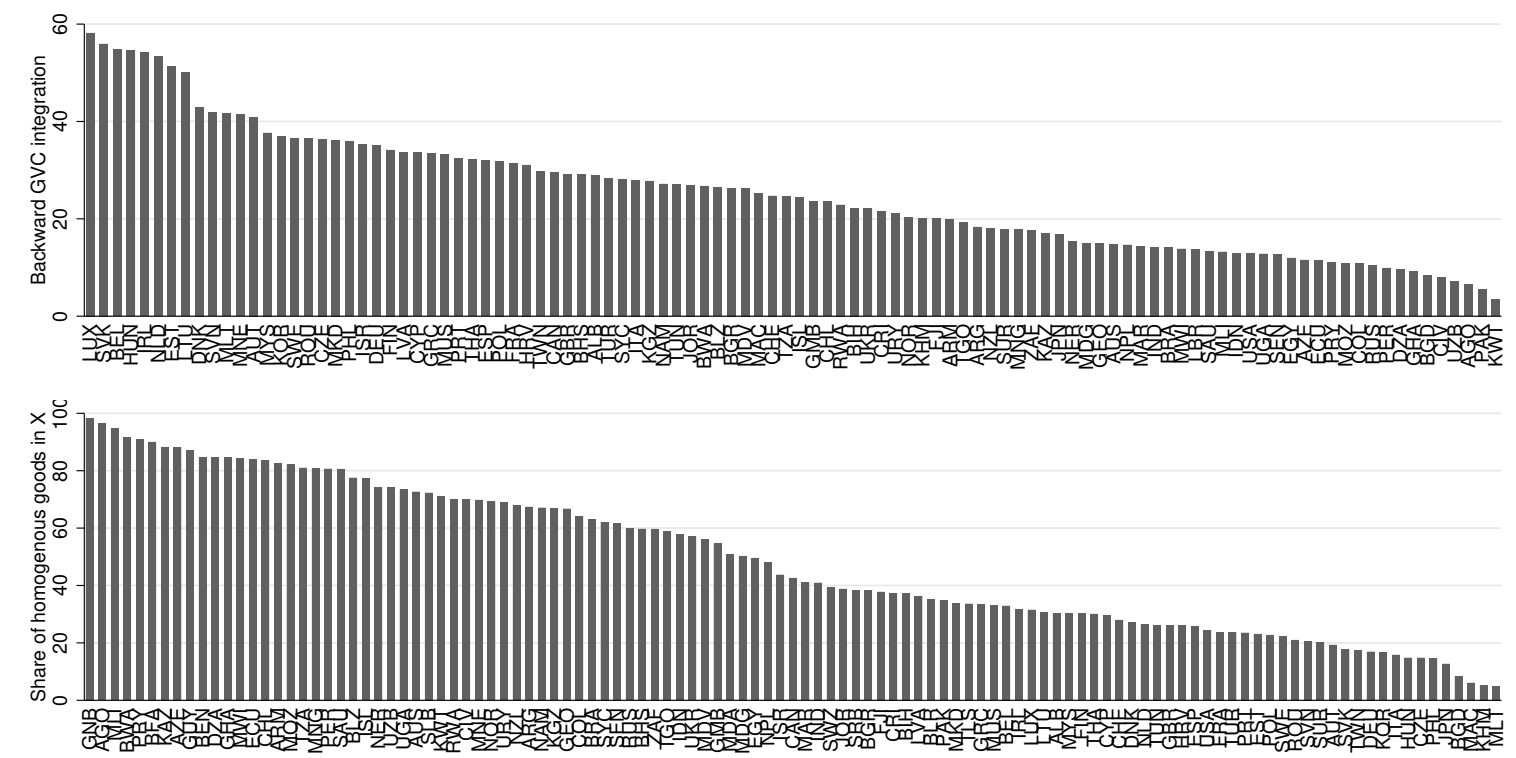

Note: The upper panel shows the average backward GVC integration as measured by the vertical specialisation index of Hummels et al. (2001) (see also Belotti et al., 2020); the lower panel shows the share of homogeneous goods in countries' exports as measured by the classification of Rauch (1999). The data are averages over 1999-2019, are from the UNCTAD-EORA database and United Nations COMTRADE. 
Figure B.2: Marginal effects of the establishment of PBoC swap lines on invoicing currency patterns

Renminbi (exports)

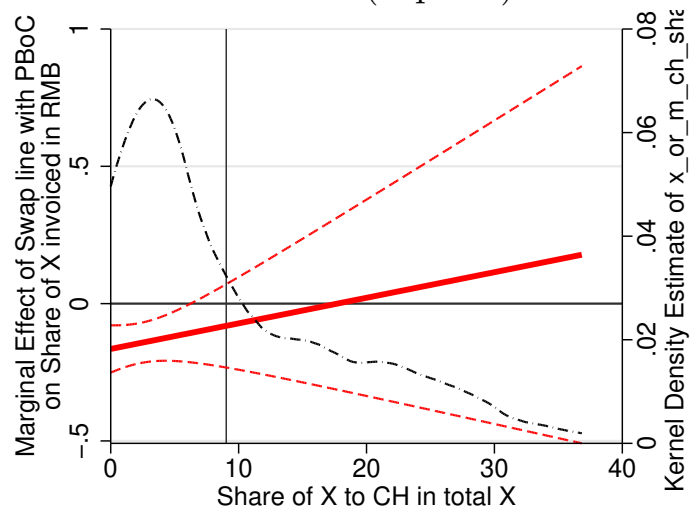

US dollar (exports)

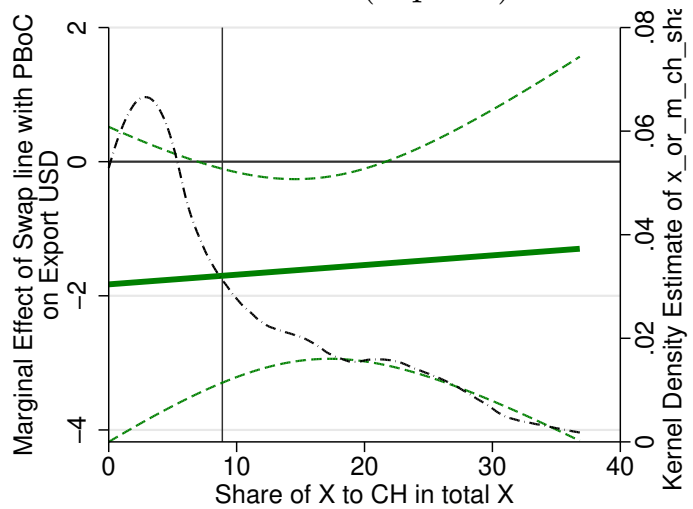

Euro (exports)

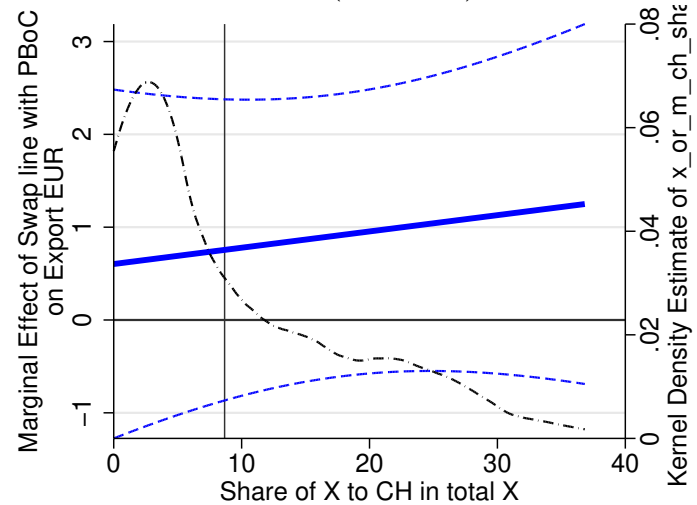

Renminbi (imports)

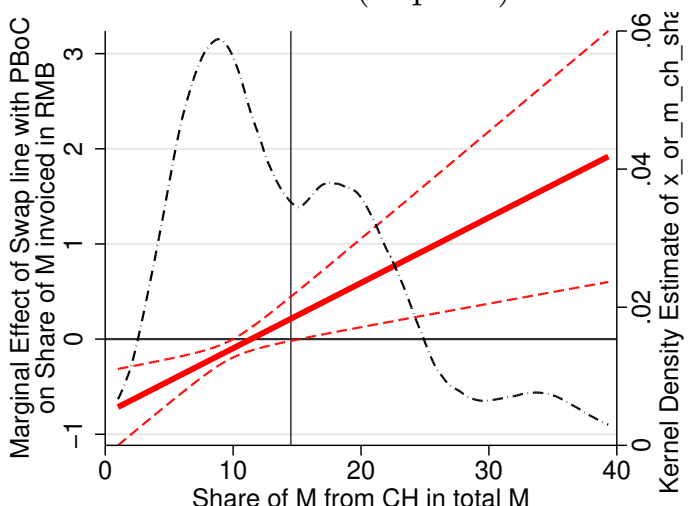

US dollar (imports)

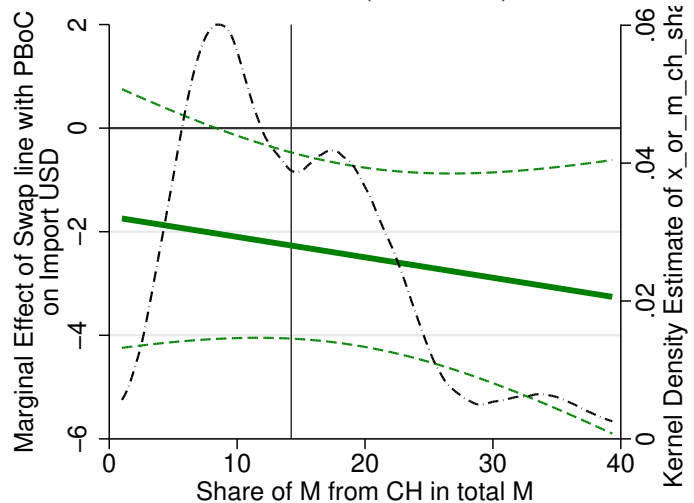

Euro (imports)

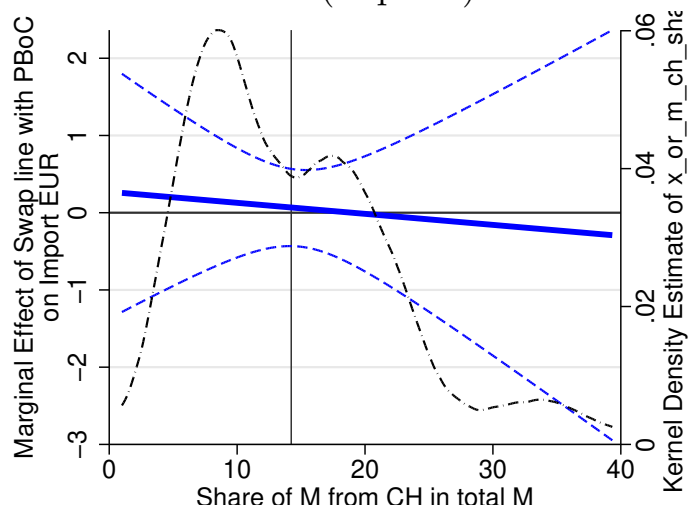

Note: The figure shows the marginal effects of PBoC swap lines on renminbi invoicing from Table 6 (columns (2) and (5)) and Table 7. The results for exports are shown in the left-hand side column, and those for imports in the right-hand side column. The solid line indicates the point estimate, the dashed lines $90 \%$ confidence bands, and the dash-dotted lines kernel density estimates of the distribution of the share of countries' exports/imports with China. 
Figure B.3: Marginal effects PBoC swap lines on invoicing currency choice for the full country sample
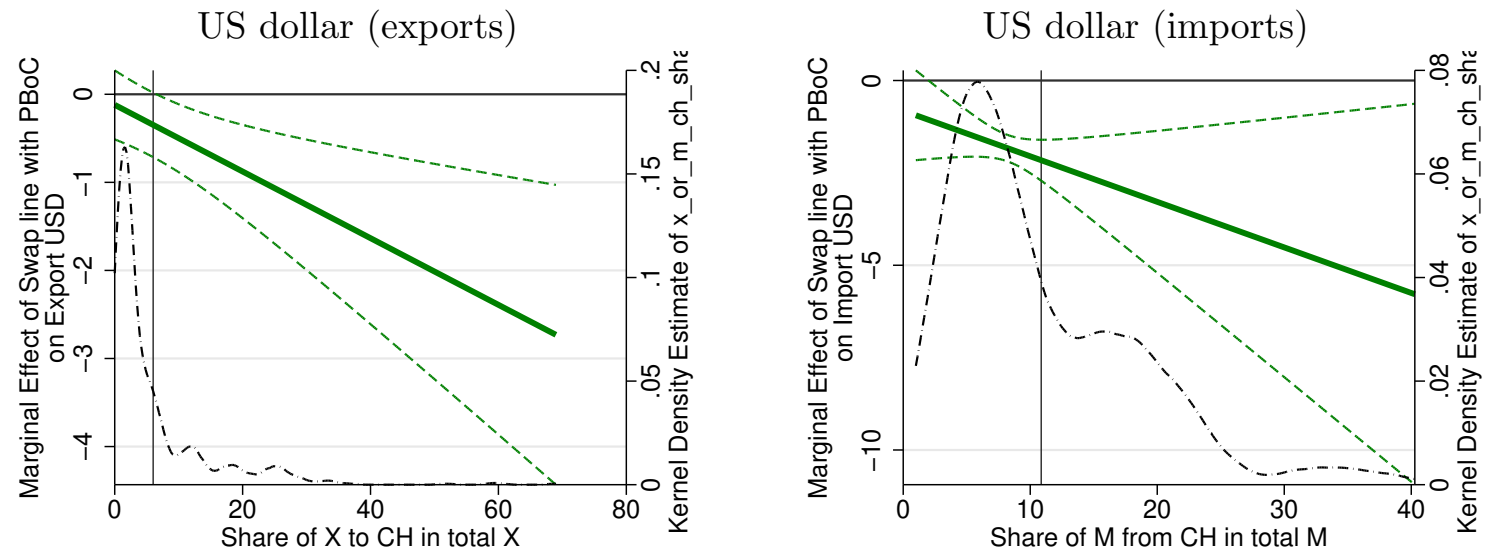

Euro (exports)
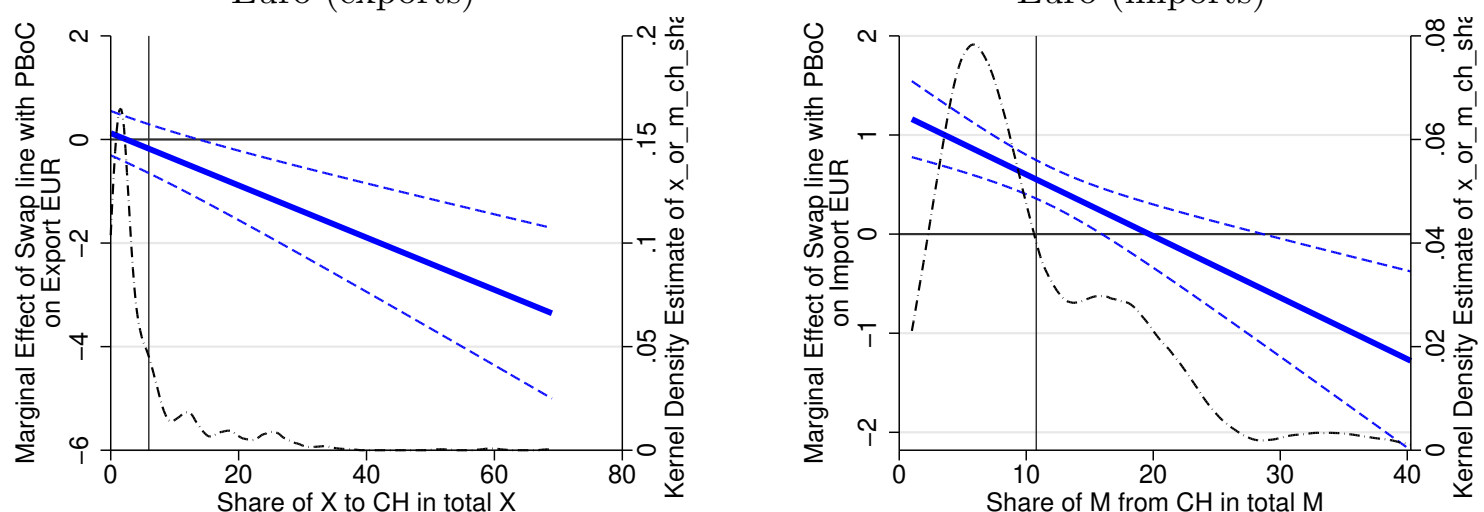

Note: The figure presents the marginal effects of $\mathrm{PBoC}$ swap lines on renminbi invoicing from Table 6 (columns (2) and (5)) and Table 7. The results for exports are shown in the left-hand side column, and those for imports in the right-hand side column. The sample is restricted to countries for which there is renminbi invoicing data. The solid lines indicate the point estimate, the dashed lines $90 \%$ confidence bands, and the dash-dotted lines kernel density estimates of the distribution of the share of countries' total exports/imports accounted for by exports to/imports from China. 


\section{Additional Regression Tables}

Table C.1: Regression results for the role of GVC integration in export invoicing currency patterns: Interactions with the share of exports to the US and the EA

\begin{tabular}{|c|c|c|c|c|c|c|}
\hline & \multicolumn{3}{|c|}{ 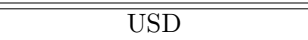 } & \multicolumn{3}{|c|}{ EUR } \\
\hline & (1) & $(2)$ & (3) & (4) & $(5)$ & (6) \\
\hline Share of homogeneous goods in total $\mathrm{X}$ & $\begin{array}{c}0.23^{* * *} \\
(0.00)\end{array}$ & $\begin{array}{c}0.20^{* * * *} \\
(0.00)\end{array}$ & $\begin{array}{c}0.23^{* * * *} \\
(0.00)\end{array}$ & $\begin{array}{c}-0.13^{* * *} \\
(0.00)\end{array}$ & $\begin{array}{c}-0.13^{* * *} \\
(0.00)\end{array}$ & $\begin{array}{c}-0.12^{* * *} \\
(0.00)\end{array}$ \\
\hline Backward GVC integration & $\begin{array}{l}-0.14 \\
(0.32)\end{array}$ & $\begin{array}{c}-0.26 \\
(0.12)\end{array}$ & $\begin{array}{c}0.01 \\
(0.93)\end{array}$ & $\begin{array}{l}0.29^{* *} \\
(0.03)\end{array}$ & $\begin{array}{c}0.17 \\
(0.17)\end{array}$ & $\begin{array}{c}0.17 \\
(0.28)\end{array}$ \\
\hline $\mathrm{x}$ share of $\mathrm{M}$ from the US in total M & & $\begin{array}{c}0.03^{* * *} \\
(0.00)\end{array}$ & $\begin{array}{c}0.03^{* * *} \\
(0.00)\end{array}$ & & & \\
\hline $\mathrm{x}$ share of $\mathrm{M}$ from the euro area in total $\mathrm{M}$ & & & & & $\begin{array}{c}0.00 \\
(0.25)\end{array}$ & $\begin{array}{c}-0.00 \\
(0.26)\end{array}$ \\
\hline Within R-squared & 0.32 & 0.37 & 0.39 & 0.36 & 0.36 & 0.43 \\
\hline Observations & 1018 & 1018 & 726 & 1025 & 1025 & 729 \\
\hline Countries & 92 & 92 & 74 & 91 & 91 & 73 \\
\hline
\end{tabular}

Note: The dependent variable is the share of countries' exports invoiced in US dollars (columns (1) to (3)) and euro (columns ((4) to (6)). Inference is based on Driscoll-Kraay robust standard errors. $p$-values are reported in parentheses below the point estimates, and $\left.{ }^{*}\left({ }^{* *}\right){ }^{[* *}\right]$ indicates statistical significance at the $10 \%(5 \%)$ [1\%] significance level. Country and time fixed effects are included in all regressions. Regressions in columns (3) and (6) do not include euro area countries. Coefficient estimates for US/EA and US dollar/euro-block trade shares as well as exchange rates are not reported to save space. The marginal effects are plotted in Figure 12. 
Table C.2: Results for regressions with interactions between trade shares and the share of homogeneous goods in total trade as well as backward GVC integration

\begin{tabular}{|c|c|c|c|c|c|c|c|c|}
\hline & \multicolumn{4}{|c|}{ Exports } & \multicolumn{4}{|c|}{ Imports } \\
\hline & $\begin{array}{c}(1) \\
\text { Base- } \\
\text { line }\end{array}$ & $\begin{array}{c}(2) \\
\text { USD }\end{array}$ & $\begin{array}{c}(3) \\
\text { Base- } \\
\text { line }\end{array}$ & $\begin{array}{c}\text { (4) } \\
\text { EUR }\end{array}$ & $\begin{array}{c}(5) \\
\text { Base- } \\
\text { line }\end{array}$ & $\begin{array}{c}(6) \\
\text { USD }\end{array}$ & $\begin{array}{c}(7) \\
\text { Base- } \\
\text { line }\end{array}$ & $\begin{array}{c}(8) \\
\text { EUR }\end{array}$ \\
\hline Share of $\mathrm{X} / \mathrm{M}$ to/from US in total $\mathrm{X} / \mathrm{M}$ & $\begin{array}{c}0.81^{* * *} \\
(0.00)\end{array}$ & $\begin{array}{c}0.83^{* * *} \\
(0.00)\end{array}$ & & & $\begin{array}{l}0.16^{*} \\
(0.09)\end{array}$ & $\begin{array}{l}0.32^{* *} \\
(0.04)\end{array}$ & & \\
\hline Share of M from non-US USD block in total M & $\begin{array}{c}0.20^{* * * *} \\
(0.00)\end{array}$ & $\begin{array}{c}0.00 \\
(0.98)\end{array}$ & & & $\begin{array}{c}0.42^{* * *} \\
(0.00)\end{array}$ & $\begin{array}{c}0.37^{* * *} \\
(0.00)\end{array}$ & & \\
\hline Share of $\mathrm{X} / \mathrm{M}$ to/from EA in total $\mathrm{X} / \mathrm{M}$ & & & $\begin{array}{c}0.27^{* * *} \\
(0.00)\end{array}$ & $\begin{array}{c}0.50^{* * *} \\
(0.00)\end{array}$ & & & $\begin{array}{c}0.42^{* * *} \\
(0.00)\end{array}$ & $\begin{array}{r}0.40^{* * * *} \\
(0.00)\end{array}$ \\
\hline Share of $M$ from non-EA EUR block in total $M$ & & & $\begin{array}{c}0.14^{* * *} \\
(0.00)\end{array}$ & $\begin{array}{c}0.05^{* * *} \\
(0.01)\end{array}$ & & & $\begin{array}{l}0.40^{* *} \\
(0.02)\end{array}$ & $\begin{array}{l}0.42^{* *} \\
(0.02)\end{array}$ \\
\hline Share of homogeneous goods in total X/M & $\begin{array}{c}0.23^{* * *} \\
(0.00)\end{array}$ & $\begin{array}{c}0.34^{* * *} \\
(0.00)\end{array}$ & $\begin{array}{c}-0.13^{* * *} \\
(0.00)\end{array}$ & $\begin{array}{c}0.07^{* * *} \\
(0.01)\end{array}$ & $\begin{array}{c}0.26^{* * *} \\
(0.00)\end{array}$ & $\begin{array}{c}0.29^{* * *} \\
(0.01)\end{array}$ & $\begin{array}{l}-0.03 \\
(0.55)\end{array}$ & $\begin{array}{c}-0.03 \\
(0.76)\end{array}$ \\
\hline Own/trading-partner backward GVCP & $\begin{array}{l}-0.14 \\
(0.32)\end{array}$ & $\begin{array}{c}-0.52^{* * *} \\
(0.01)\end{array}$ & $\begin{array}{l}0.29^{* *} \\
(0.03)\end{array}$ & $\begin{array}{c}0.32^{* * *} \\
(0.00)\end{array}$ & $\begin{array}{c}0.10 \\
(0.86)\end{array}$ & $\begin{array}{c}0.48 \\
(0.40)\end{array}$ & $\begin{array}{l}-0.64 \\
(0.18)\end{array}$ & $\begin{array}{r}-1.01^{* *} \\
(0.05)\end{array}$ \\
\hline Share of $\mathrm{X} / \mathrm{M}$ to/from US in total $\mathrm{X} / \mathrm{M} \times$ Share of hom. goods $\mathrm{X} / \mathrm{M}$ in total $\mathrm{X} / \mathrm{M}$ & & $\begin{array}{c}-0.02^{* * *} \\
(0.00)\end{array}$ & & & & $\begin{array}{l}-0.00 \\
(0.11)\end{array}$ & & \\
\hline Share of $\mathrm{X} / \mathrm{M}$ to/from non-US USD block in total $\mathrm{X} / \mathrm{M} \times$ Share of hom. goods $\mathrm{X} / \mathrm{M}$ in & & $\begin{array}{l}-0.00 \\
(0.50)\end{array}$ & & & & $\begin{array}{c}0.00 \\
(1.00)\end{array}$ & & \\
\hline Share of $\mathrm{X} / \mathrm{M}$ to/from EA in total $\mathrm{X} / \mathrm{M} \mathrm{x}$ Share of hom. goods $\mathrm{X} / \mathrm{M}$ in total $\mathrm{X} / \mathrm{M}$ & & & & $\begin{array}{c}-0.01^{* * *} \\
(0.00)\end{array}$ & & & & $\begin{array}{l}-0.00 \\
(0.98)\end{array}$ \\
\hline Share of $\mathrm{X} / \mathrm{M}$ to/from non-EA EUR block in total $\mathrm{X} / \mathrm{M} \times$ Share of hom. goods $\mathrm{X} / \mathrm{M}$ in & & & & $\begin{array}{c}0.01 \\
(0.11)\end{array}$ & & & & $\begin{array}{l}-0.02 \\
(0.22)\end{array}$ \\
\hline Share of M from US in total M x Backward GVC integration & & $\begin{array}{l}0.02^{* *} \\
(0.02)\end{array}$ & & & & $\begin{array}{c}0.01^{* * *} \\
(0.01)\end{array}$ & & \\
\hline Share of M from non-US USD block in total M x Backward GVC integration & & $\begin{array}{c}0.01^{* * *} \\
(0.00)\end{array}$ & & & & $\begin{array}{l}0.01^{* *} \\
(0.02)\end{array}$ & & \\
\hline Share of M from EA in total M x Backward GVC integration & & & & $\begin{array}{l}0.00^{* *} \\
(0.03)\end{array}$ & & & & $\begin{array}{l}0.01^{* *} \\
(0.01)\end{array}$ \\
\hline Share of M from non-EA EUR block in total M x Backward GVC integration & & & & $\begin{array}{c}-0.03^{* * * *} \\
(0.01) \\
\end{array}$ & & & & $\begin{array}{c}-0.00 \\
(0.58) \\
\end{array}$ \\
\hline Within R-squared & 0.32 & 0.40 & 0.36 & 0.42 & 0.23 & 0.25 & 0.30 & 0.32 \\
\hline Observations & 1018 & 1018 & 1025 & 1025 & 1101 & 1101 & 1098 & 1098 \\
\hline Countries & 92 & 92 & 91 & 91 & 99 & 99 & 98 & 98 \\
\hline
\end{tabular}

Note: The dependent variable is the share of countries' exports invoiced in US dollars (columns (1) to (3)) and euro (columns ((4) to (6)). Inference is based on Driscoll-Kraay robust standard errors. $p$-values are reported in parentheses below the point estimates, and * $\left({ }^{* *}\right)[* * *]$ indicates statistical significance at the $10 \%(5 \%)$ [1\%] significance level. Country and time fixed effects are included in all regressions. Regressions in columns (3) and (6) do not include euro area countries. The marginal effects are plotted in Figure 12. 
Table C.3: Regression results for the role of the increase in exports to/imports from China in invoicing currency patterns for the full country sample

\begin{tabular}{lccccccccccc}
\hline \hline & \multicolumn{4}{c}{ Exports } & & \multicolumn{4}{c}{ Imports } \\
\cline { 2 - 3 } & $(1)$ & $(2)$ & $(3)$ & $(4)$ & & $(5)$ & & $(6)$ & $(7)$ & $(8)$ \\
& USD & EUR & Other & RMB & & USD & EUR & Other & RMB \\
\hline Share of X/M to/from CH in total X/M & $0.29^{* * *}$ & -0.01 & -0.02 & 0.02 & & $0.28^{* * *}$ & -0.06 & -0.04 & 0.02 \\
& $(0.00)$ & $(0.90)$ & $(0.30)$ & $(0.10)$ & & $(0.00)$ & $(0.38)$ & $(0.62)$ & $(0.16)$ \\
\hline Within R-squared & 0.24 & 0.26 & 0.04 & 0.14 & & 0.21 & & 0.34 & 0.06 & 0.24 \\
Observations & 585 & 592 & 591 & 214 & & 640 & & 635 & 635 & 262 \\
Countries & 87 & 87 & 87 & 38 & & 97 & 96 & 96 & 49 \\
\hline \hline
\end{tabular}

Note: The dependent variable is the share of countries' exports and imports invoiced in US dollars (columns (1) and $(4)$ ), in euro (columns $((2)$ and (5)), in currencies other than the US dollar and the euro (columns ((3) and (6)), and in renminbi (columns (4) and (8)). For each currency, the sample includes all countries for which invoicing shares are available. Inference is based on Driscoll-Kraay robust standard errors. $p$-values are reported in parentheses below the point estimates, and ${ }^{*}\left({ }^{*}\right)\left[{ }^{* *}\right]$ indicates statistical significance at the $10 \%(5 \%)$ [1\%] significance level. Country and time fixed effects are included in all regressions. The coefficient estimates for the share of homogeneous goods in total trade, GVC integration, US/EA and US dollar/euro-block trade shares as well as exchange rates are not reported to save space.

Table C.4: Regression results for the role of the increase in exports to/imports from China for invoicing currency patterns across European and non-European countries for the full country sample

\begin{tabular}{|c|c|c|c|c|c|c|c|c|}
\hline & \multicolumn{4}{|c|}{ Exports } & \multicolumn{4}{|c|}{ Imports } \\
\hline & (1) & (2) & (3) & (4) & $(5)$ & (6) & (7) & $(8)$ \\
\hline & USD & EUR & Other & RMB & USD & EUR & Other & RMB \\
\hline \multicolumn{9}{|c|}{ Share of $\mathrm{X} / \mathrm{M}$ to/from $\mathrm{CH}$ in total $\mathrm{X} / \mathrm{M}$} \\
\hline $\mathrm{x}$ Europe dummy & $\begin{array}{l}1.27^{* *} \\
(0.02)\end{array}$ & $\begin{array}{c}-0.55^{*} \\
(0.07)\end{array}$ & $\begin{array}{c}-0.62^{* *} \\
(0.01)\end{array}$ & $\begin{array}{l}-0.03 \\
(0.10)\end{array}$ & $\begin{array}{c}-0.26^{*} \\
(0.08)\end{array}$ & $\begin{array}{c}0.67^{* * *} \\
(0.00)\end{array}$ & $\begin{array}{c}-0.21^{* * * *} \\
(0.00)\end{array}$ & $\begin{array}{c}-0.07^{* * *} \\
(0.00)\end{array}$ \\
\hline $\mathrm{x}$ Non-Europe dummy & $\begin{array}{c}0.21^{* * *} \\
(0.00)\end{array}$ & $\begin{array}{c}0.03 \\
(0.53)\end{array}$ & $\begin{array}{c}0.02 \\
(0.42)\end{array}$ & $\begin{array}{c}0.02^{*} \\
(0.08)\end{array}$ & $\begin{array}{c}0.35^{* * *} \\
(0.00)\end{array}$ & $\begin{array}{c}-0.13 \\
(0.14)\end{array}$ & $\begin{array}{l}-0.02 \\
(0.78)\end{array}$ & $\begin{array}{c}0.02 \\
(0.11)\end{array}$ \\
\hline Within R-squared & 0.27 & 0.27 & 0.06 & 0.15 & 0.22 & 0.37 & 0.06 & 0.26 \\
\hline Observations & 585 & 592 & 591 & 214 & 640 & 635 & 635 & 262 \\
\hline Countries & 87 & 87 & 87 & 38 & 97 & 96 & 96 & 49 \\
\hline
\end{tabular}

Note: The dependent variable is the share of countries' exports and imports invoiced in US dollars (columns (1) and (4)), in euro (columns $((2)$ and (5)), in currencies other than the US dollar and the euro (columns ((3) and (6)), and in renminbi (columns (4) and (8)). For each currency, the sample includes all countries for which invoicing shares are available. Inference is based on Driscoll-Kraay robust standard errors. $p$-values are reported in parentheses below the point estimates, and $\left.{ }^{*}\left({ }^{* *}\right){ }^{[* *}\right]$ indicates statistical significance at the $10 \%(5 \%)[1 \%]$ significance level. Country and time fixed effects are included in all regressions. The coefficient estimates for the share of homogeneous goods in total trade, GVC integration, US/EA and US dollar/euro-block trade shares as well as exchange rates are not reported to save space. The last row provides information on the number of countries for which the regional dummy variable equals unity in the regression in each column in the order they appear in the rows in the main part of the regression table. 
Table C.5: Regression results for the role of the increase in exports to/imports from China for invoicing currency patterns across regions for the full country sample

\begin{tabular}{|c|c|c|c|c|c|c|c|c|}
\hline & \multicolumn{4}{|c|}{ Exports } & \multicolumn{4}{|c|}{ Imports } \\
\hline & $(1)$ & $(2)$ & $(3)$ & $(4)$ & $\begin{array}{c}(5) \\
\text { USD }\end{array}$ & $\begin{array}{c}(6) \\
\text { (6UB }\end{array}$ & $\begin{array}{c}(7) \\
\text { Other }\end{array}$ & $(8)$ \\
\hline \multicolumn{9}{|l|}{ Share of $\mathrm{X} / \mathrm{M}$ to/from $\mathrm{CH}$ in total $\mathrm{X} / \mathrm{M}$} \\
\hline x Europe dummy & $\begin{array}{l}1.28^{* *} \\
(0.02)\end{array}$ & $\begin{array}{l}-0.57^{*} \\
(0.07)\end{array}$ & $\begin{array}{c}-0.60^{* *} \\
(0.01)\end{array}$ & $\begin{array}{c}-0.03^{*} \\
(0.08)\end{array}$ & $\begin{array}{l}-0.20 \\
(0.16)\end{array}$ & $\begin{array}{c}0.65^{* * *} \\
(0.00)\end{array}$ & $\begin{array}{c}-0.24^{* * *} \\
(0.00)\end{array}$ & $\begin{array}{c}-0.06^{* * *} \\
(0.00)\end{array}$ \\
\hline x S-E/E Asia dummy & $\begin{array}{c}0.29^{* * *} \\
(0.00)\end{array}$ & $\begin{array}{c}-0.30^{* *} \\
(0.01)\end{array}$ & $\begin{array}{l}0.15^{* *} \\
(0.04)\end{array}$ & $\begin{array}{l}-0.03 \\
(0.32)\end{array}$ & $\begin{array}{c}0.88^{* * *} \\
(0.00)\end{array}$ & $\begin{array}{c}-0.30^{* * *} \\
(0.00)\end{array}$ & $\begin{array}{c}-0.40^{* * *} \\
(0.00)\end{array}$ & $\begin{array}{c}0.10^{* * * *} \\
(0.00)\end{array}$ \\
\hline x Latin America dummy & $\begin{array}{c}0.26^{* * *} \\
(0.00)\end{array}$ & $\begin{array}{l}-0.05 \\
(0.32)\end{array}$ & $\begin{array}{c}0.03 \\
(0.61)\end{array}$ & $\begin{array}{c}-0.01^{* * *} \\
(0.00)\end{array}$ & $\begin{array}{l}0.53^{* *} \\
(0.03)\end{array}$ & $\begin{array}{c}-0.35^{* * *} \\
(0.00)\end{array}$ & $\begin{array}{c}0.01 \\
(0.94)\end{array}$ & $\begin{array}{l}-0.02 \\
(0.11)\end{array}$ \\
\hline x Oceania dummy & $\begin{array}{c}0.40^{* * * *} \\
(0.00)\end{array}$ & $\begin{array}{c}-0.13^{* *} \\
(0.01)\end{array}$ & $\begin{array}{l}-0.09 \\
(0.27)\end{array}$ & $\begin{array}{l}0.12^{* *} \\
(0.01)\end{array}$ & $\begin{array}{l}1.14^{*} \\
(0.05)\end{array}$ & $\begin{array}{l}-0.11 \\
(0.61)\end{array}$ & $\begin{array}{l}-0.71 \\
(0.35)\end{array}$ & $\begin{array}{c}0.12^{* * * *} \\
(0.00)\end{array}$ \\
\hline x Sub-Saharan Africa dummy & $\begin{array}{l}0.19^{* *} \\
(0.03)\end{array}$ & $\begin{array}{l}0.11^{*} \\
(0.08)\end{array}$ & $\begin{array}{l}-0.07^{*} \\
(0.06)\end{array}$ & $\begin{array}{c}0.01 \\
(0.32)\end{array}$ & $\begin{array}{c}0.11 \\
(0.53)\end{array}$ & $\begin{array}{c}0.02 \\
(0.91)\end{array}$ & $\begin{array}{c}0.04 \\
(0.83)\end{array}$ & $\begin{array}{c}0.01 \\
(0.48)\end{array}$ \\
\hline Within R-squared & 0.27 & 0.28 & 0.08 & 0.31 & 0.25 & 0.38 & 0.10 & 0.37 \\
\hline Observations & 585 & 592 & 591 & 214 & 640 & 635 & 635 & 262 \\
\hline $\begin{array}{l}\text { Countries } \\
\text { Countries in groups }\end{array}$ & $\begin{array}{l}\quad 87 \\
35 / 9 / \\
10 / 3 / 12\end{array}$ & $\begin{array}{c}\quad 87 \\
35 / 9 / \\
10 / 3 / 12\end{array}$ & $\begin{array}{l}\quad 87 \\
35 / 9 / \\
10 / 3 / 12\end{array}$ & $\begin{array}{l}\quad 38 \\
5 / 8 / \\
8 / 2 / 6\end{array}$ & $\begin{array}{c}97 \\
38 / 10 / \\
11 / 4 / 15\end{array}$ & $\begin{array}{c}96 \\
38 / 10 / \\
11 / 3 / 15\end{array}$ & \begin{tabular}{c}
\multicolumn{1}{c}{96} \\
$38 / 10 /$ \\
$11 / 3 / 15$
\end{tabular} & $\begin{array}{l}\quad 49 \\
8 / 10 / \\
7 / 2 / 10\end{array}$ \\
\hline
\end{tabular}

Note: The dependent variable is the share of countries' exports and imports invoiced in US dollars (columns (1) and (4)), in euro (columns $((2)$ and (5)), in currencies other than the US dollar and the euro (columns ((3) and (6)), and in renminbi (columns (4) and (8)). For each currency, the sample includes all countries for which invoicing shares are available. Inference is based on Driscoll-Kraay robust standard errors. $p$-values are reported in parentheses below the point estimates, and ${ }^{*}\left(^{* *}\right)\left[{ }^{* * *}\right]$ indicates statistical significance at the $10 \%(5 \%)[1 \%]$ significance level. Country and time fixed effects are included in all regressions. The coefficient estimates for the share of homogeneous goods in total trade, GVC integration, US/EA and US dollar/euro-block trade shares as well as exchange rates are not reported to save space. The last row provides information on the number of countries for which the regional dummy variable equals unity in the regression in each column in the order they appear in the rows in the main part of the regression table.

Table C.6: The effects of the establishment of PBoC swap lines on renminbi invoicing when controlling for additional dimensions of China's foreign policy

\begin{tabular}{|c|c|c|c|c|c|c|c|c|}
\hline & \multicolumn{4}{|c|}{ Exports } & \multicolumn{4}{|c|}{ Imports } \\
\hline & (1) & (2) & (3) & (4) & (5) & (6) & (7) & (8) \\
\hline & USD & EUR & RMB & Other & USD & EUR & RMB & Other \\
\hline Swap line with PBoC & $\begin{array}{l}-1.83 \\
(0.22)\end{array}$ & $\begin{array}{c}0.60 \\
(0.61)\end{array}$ & $\begin{array}{l}-0.08 \\
(0.11)\end{array}$ & $\begin{array}{c}0.61 \\
(0.15)\end{array}$ & $\begin{array}{l}-1.71 \\
(0.30)\end{array}$ & $\begin{array}{c}0.27 \\
(0.79)\end{array}$ & $\begin{array}{c}0.77^{\text {** }} \\
(0.03)\end{array}$ & $\begin{array}{c}2.40 \\
(0.15)\end{array}$ \\
\hline $\mathrm{x}$ share of $\mathrm{X} / \mathrm{M}$ accounted for by China & $\begin{array}{c}0.01 \\
(0.85)\end{array}$ & $\begin{array}{c}0.02 \\
(0.65) \\
\end{array}$ & $\begin{array}{l}-0.00 \\
(0.90)\end{array}$ & $\begin{array}{l}-0.25^{*} \\
(0.05)\end{array}$ & $\begin{array}{l}-0.04 \\
(0.52)\end{array}$ & $\begin{array}{c}-0.01 \\
(0.83)\end{array}$ & $\begin{array}{c}0.07^{* *} \\
(0.04)\end{array}$ & $\begin{array}{c}-0.02 \\
(0.89)\end{array}$ \\
\hline Within R-squared & 0.41 & 0.41 & 0.49 & 0.19 & 0.31 & 0.40 & 0.55 & 0.25 \\
\hline Observations & 292 & 300 & 236 & 228 & 350 & 350 & 288 & 281 \\
\hline Countries & 37 & 37 & 37 & 36 & 48 & 48 & 48 & 47 \\
\hline Effect of PBoC swap line for high CHN exposure & $\begin{array}{c}-1.57^{*} \\
(0.08)\end{array}$ & $\begin{array}{l}0.91 \\
(0.34)\end{array}$ & $\begin{array}{l}-0.11 \\
(0.59)\end{array}$ & $\begin{array}{c}-3.93^{*} \\
(0.08)\end{array}$ & $\begin{array}{c}-2.57^{* *} \\
(0.03)\end{array}$ & $\begin{array}{c}-0.04 \\
(0.94)\end{array}$ & $\begin{array}{c}0.77^{* *} \\
(0.05)\end{array}$ & $\begin{array}{l}1.91 \\
(0.34)\end{array}$ \\
\hline
\end{tabular}

Note: The dependent variable is the share of countries' exports/imports invoiced in US dollars (column $(1) /(5))$, in euros (column $((2) /(6))$, in renminbi (column $((3) /(7))$, and in currencies other than the US dollar, the euro, and the renminbi $($ column $(4) /(8))$. Inference is based on Driscoll-Kraay robust standard errors. $p$-values are reported in parentheses below the point estimates, and * $\left.\left({ }^{* *}\right)^{[* *}\right]$ indicates statistical significance at the $10 \%(5 \%)$ [1\%] significance level. Country and time fixed effects are included in all regressions. The coefficient estimates for the share of homogeneous goods in total trade, backward GVC integration, US/EA and US dollar/euro-block trade shares as well as exchange rates are not reported to save space. The last row provides the marginal effects of the PBoC's currency swap lines on renminbi invoicing shares, evaluated at a 'high' share of countries' trade with China. A 'high' share refers to the mean plus one standard deviation of the cross-country distribution of trade shares with China. The associated marginal effects are plotted in Figure 13. 
Table C.7: Regression results for the role of PBoC swap lines for renminbi invoicing: All currencies for the full country sample

\begin{tabular}{|c|c|c|c|c|c|c|c|c|}
\hline & \multicolumn{4}{|c|}{ Exports } & \multicolumn{4}{|c|}{ Imports } \\
\hline & $(1)$ & $(2)$ & $(3)$ & $(4)$ & $(5)$ & (6) & (7) & $(8)$ \\
\hline & USD & EUR & Other & RMB & USD & EUR & Other & RMB \\
\hline Swap line with $\mathrm{PBoC}$ & $\begin{array}{l}-0.12 \\
(0.62)\end{array}$ & $\begin{array}{c}0.12 \\
(0.65)\end{array}$ & $\begin{array}{c}0.20 \\
(0.59)\end{array}$ & $\begin{array}{c}-0.34^{* * *} \\
(0.01)\end{array}$ & $\begin{array}{l}-0.82 \\
(0.35)\end{array}$ & $\begin{array}{c}1.22^{* * *} \\
(0.00)\end{array}$ & $\begin{array}{l}-0.22 \\
(0.70)\end{array}$ & $\begin{array}{c}-0.95^{* *} \\
(0.02)\end{array}$ \\
\hline $\mathrm{x}$ share of $\mathrm{X} / \mathrm{M}$ accounted for by China & $\begin{array}{c}-0.04^{* *} \\
(0.04)\end{array}$ & $\begin{array}{c}-0.05^{* * *} \\
(0.00)\end{array}$ & $\begin{array}{l}-0.01 \\
(0.87)\end{array}$ & $\begin{array}{l}0.03^{*} \\
(0.09)\end{array}$ & $\begin{array}{l}-0.12 \\
(0.23)\end{array}$ & $\begin{array}{c}-0.06^{* * *} \\
(0.01)\end{array}$ & $\begin{array}{l}0.21^{* *} \\
(0.05)\end{array}$ & $\begin{array}{l}0.08^{*} \\
(0.06)\end{array}$ \\
\hline Within R-squared & 0.29 & 0.25 & 0.03 & 0.27 & 0.24 & 0.33 & 0.12 & 0.40 \\
\hline Observations & 724 & 732 & 731 & 240 & 795 & 790 & 790 & 292 \\
\hline Countries & 87 & 87 & 87 & 38 & 98 & 97 & 97 & 49 \\
\hline Effect of PBoC swap line for high CHN exposure & $\begin{array}{l}-0.66^{* *} \\
(0.03)\end{array}$ & $\begin{array}{l}-0.59 \\
(0.12)\end{array}$ & $\begin{array}{l}0.11 \\
(0.78)\end{array}$ & $\begin{array}{l}0.15 \\
(0.43)\end{array}$ & $\begin{array}{c}-3.07^{* * *} \\
(0.01)\end{array}$ & $\begin{array}{c}0.09 \\
(0.59)\end{array}$ & $\begin{array}{c}3.61^{* * * *} \\
(0.01)\end{array}$ & $\begin{array}{c}0.82 \\
(0.12)\end{array}$ \\
\hline
\end{tabular}

Note: The dependent variable is the share of countries' exports (columns (1) to (4)) and imports (columns (5) to (8)) invoiced in US dollar (columns (1) and (5)), in euro (columns (2) and (6)), in currencies other than US dollar and euro (columns (3) and (7)) and in renminbi (columns (4) and (8)). For each currency, the sample includes all countries for which invoicing shares are available. Inference is based on Driscoll-Kraay robust standard errors. $p$-values are reported in parentheses below the point estimates, and $\left.{ }^{*}\left({ }^{* *}\right){ }^{[* *}\right]$ indicates statistical significance at the 10\% (5\%) [1\%] significance level. Country and time fixed effects are included in all regressions. The coefficient estimates for the share of homogeneous goods in total trade, GVC integration, US/EA and US dollar/euro-block trade shares as well as exchange rates are not reported to save space. The last row provides the marginal effects of PBoC swap lines on renminbi invoicing shares, evaluated at 'high' exposure of countries' exports to/imports from China. 'High' exposure refers to the mean plus one standard deviation of the cross-country distribution of export/import shares accounted for by China. The marginal effects are plotted in Figure B.3. 